\title{
SANGIREESCHE 'TEKST'EN.
}

ME'T VERTALING EN AANTEEKENINGEN UITGEGEVEN DOOR

N. A D R I A N I.

\section{Inleiding.}

De volgende teksten zijn uitgegeven naar handschriften, die ongeveer 10 jaar geleden, door de zorg van den heer E. T. Steller te Manganitoe, zijn opgeschreven door eenigen zijner Sangireesche kweekelingen en door Mejuffrouw C. Steller aan het K. Institunt zijn afgestaan. Op bl. 5 van de Inleiding van mijn Proefschrift heb ik ze reeds vermeld.

Deze verzameling bevat de voornaamste verhalen, die de Sangireezen elkaâr vertellen, wanneer zịj na gemeenschappelịk verricht werk, zooals rijstplanten, rijstplukken, enz. (alleen niet bij de werkzaamheden die op zee geschieden) des avonds bijeen zitten in den maneschijn. Behalve deze Bio's of Bawio's zijn er Tatinggung's (Raadsels), die bij dezelfde gelegenheden worden gebruikt. De beschrijvingen van inlandsche plechtigheden en gebruiken zijn terzelfder tijd, op verzoek van den heer Steller sameugesteld en staan dus buiten de eigenlijke Sangireesche Letterkunde.

Het poëtische gedeelte bestaat uit Sasambo's, zangen van twee regels, die achter elkatr gezongen worden op de prauw, bij 't roeien, of ook door twee personen, die elkaâr toezingen kakumbaede's of heldenzangen, alleen door mannen gexongen, bij offerplechtigheden en bij de begrafenis van een aanzienlijke en 't daaraan voorafgaande bewaken van het lijk - en ka lanto's of kakalanto's, die vooral bij shamanistische ceremoniën wordeu gebruikt.

Voorts zijn er nog bijgevoegd: tooverspreuken, dienende om kwade voorteekenen te bezweren, of zich te beveiligen voor de vervolgingen van booze geesten. Ook worden zij uitgesproken bij

5e Volgr. VIII. 
't zetten van de hoofdpalen van een huis. Ten slotte komen eenige versjes, door de kinderen gezongen bij sommige spelletjes, zooals aftellen en dergelijke.

Volledigheidshalve zijn ook opgenomen de teksten door Dr. Riedel in 1867 en ' 68 in druk gegeven. (Sang. Spraakkunst, bl. 4, No. 17, 18 en 19). Daar Dr. Riedel de eerste is geweest, die iets van de letterkunde der Sangireezen uitgaf, is zijne spelling verschillend van 't door Mej. Steller en mij gevolgde stelsel, ik heb ze dus daarnaar veranderd.

De teksten zijn zooveel mogelijk geheel naar de handschriften uitgegeven. Enkele kleine veranderingen zijn gemaakt, zooals 't vervangen van een Maleisch woord door een Sangireesch of 't omzetten van een zin, die onder invloed van 't Maleisch of 't Hollandsch was opgesteld. De cijfers verwijzen naar de bladzijden mijner Sangireesche Spraakkunst.

In de volgorde der Bio's is de inhoud tot leiddraad genomen. 't Eerstè verhaal (Bẹ̆ken Nabaḷạ) staat door zuiverheid van taal en belangrijkheid van inhoud bovenaan. Daarop volgen de verhalen waarin de Aap eene hoofdrol speelt, vervolgens nog andere dieren-sprookjes en daarop de verhalen waarin alleen van menschen wordt gesproken en die meer op geschiedenissen gelijken. Dan komen de stukken die op inlandsche plechtigheden en gebruiken betrekking hebben en ten slotte de raadsels, kinderversjes, tooverspreuken, sasambo's en kakal̨antọ's.

Mij blijft nog over met hartelijken dank te spreken van het groote aandeel, dat Mej. Steller aan dezen arbeid heeft gehad, door het verleenen van hare welwillende hulp bij de vertaling en de verbetering der handschriften en bij de correctie der drukproeven,

Hilversum, September 1893. 
I.

BĔKEN NABALA.

Tangú nạun piạ tau i rĕdua tahatuari, iakang e i Nabaḷạ, tuari e i Kalelọ d. wawinen dĕdua e i Wĕmbuang areng-e. Kawing i Nabal̦a e i Mẹ̆konda, areng-e, ipag' i Nabaḷa e i sire pitu esẹ kẹ̆bị, kụ areng-e mĕngkatewe i Aral̦ung, ĕndạ̣ i sire pitu e.

Tangú su sahĕllo i Nabaḷa e mĕngkatewe nẹ̆bera su tuarine r. su manga ipag-e e: "I kitẹ den sumenggọ, kụ sarang íni sio hẹ̆bi, mẹ̆buạ e." Kutẹu tuarine simimbang: "I kitẹ mamundalẹ̆, kụ ĕndaị tạ sakaeng i kitẹ uté!" Angkúng i Nabaḷạ: "Be! pamilikang u sion katau e sarang sio hẹ̆bi relain tamasahawụ?" Masé i Nabalạ e nẹ̆bera si sire: "Diọello i kitẹ manuwang kalu." Dokeng kaĕlônge i Nabaḷa e mĕngkatewe nẹ̆bangung kimaiang su tukadẹ̆ e r. nẹ̆bera su tuarine r. manga ipag-e e: "Baļiung asa-kona, lonsong diọko kumbiwị." Ené tuarine r. manga ipag-e e mĕngkatewe nĕmpangasa.

Sarang nasue, bawa naụ̣ tuarine e u: "Bạ̣iung sen bọu niasa, lonsong bọu kinumbiwị; kurang-e kate rumal̨eng." Tangú i Kalelọ d. i Araḷung pitu e nahundaḷengke nanuwang kalu. Arí taraịe su ral̦eng e, kutẹu kai nitondông u tĕmpu, namotọ dą̧eng e: Sarang kai kerene, i Kalelọ e sasaẹ nẹ̆suḷe naụ̣ tuhang-e, batụ piạ lawe ene.

Sarang i Kalelọ ěndạ̣ mạdangeng e, sen nipakiwaḷong i Nabaḷạ ; angkûng-e: "Iạ makiwal̨on hombang, makiuḷi u niěbạ, mĕnsang apạe hombang-u, Kalelọ?" Tuarine simimbang u: "Kamageng makiwallon hombang, makiuḷi u niĕbạ: hombangku e, těmpu namotọ dal̨eng." Sarang i Nabạ̣ạ nakaringihẹ̆ ene, kimakurung mase nẹ̆bera: "Sen bọu takụ niĕnâng, buạen nisipirang, kai lawẹ be mapia, Kalelọ."

Bọu ene i Kalelọ e mĕngkatewe tarạ̣, kụ i sire mĕngkatewe nẹ̆deạ kalu. Sarang i sire nakareạ kalu areng-e Lampawanua, kutẹu nanuwangke, kụ buhụ́e sĕngkapilị e, kai piạ ḷ̆ěndu noghọ d. timělla soḷong tanaẹ. I Kalelọ e sasaẹewe nauḷ tuhang-e. Sarang nikasilon Nabaḷạ e, mĕngkatewe nipakiwaļông, angkûng-e: "Iạ makiwal̨on hombang, makiụ̣i u niĕbạ: kai hombangke kereapa?" Angkûng i Kalelọ e u: Kamageng makiwal̦on hombang, makiụ̣i u niĕbạ: hombangku e manụ lĕndu noghọ timĕllạ soḷ̂ng tanaẹ." 
Sarang i Nabaḷạ nakaringihẹ̆ ene, saụewe nẹ̆bera u: "Kamageng kai lawẹ ini e, Kalelọ, lawẹbe mapia!" Kutẹu wawinene i Wĕmbuang kai nakaringihẹ̆, kụ ěnnaẹ simĕbang d. nẹ̆bera: "Kai kere su naungku Kakạ, pĕllọ su ĕndumangku, ute pẹ̆deạe pato (sakaeng) waḷine." Arawe i Nabalạ e kai simimbang u: "Tawe mimang lawẹ, Bĕmbuang: lawe e kai ipạnĕnseho ; lawẹ ĕndọu takụ ipĕllọ su likudẹ̆."

Bọue i Kalelọ e saụewe tarạ̣, kụ sarang narĕnta, i sire apidẹ̆ nanuwang. Kutẹu sarang nahakáe, lelang u kalu e kai nanimbuhung. Sarang kai kerenẹe wue, i Kalelọ e saụewe sasaẹ naụ̣ si Nabalạ. Sarang kinasilon Nabạạ e, mĕngkatewe nakiwal̨o, angkûng-e: "Iạ sạ̣ makiwaḷon sombang, makiụ̣ u niĕbạ.. Angkûng i Kalelọ e u: "Kamagengu makiwal̨on hombang, makiuḷi u niĕbạ; - hombangku e: lelang u kalu nanimbuhung." I Nabap̣ạ simimbang: "Kamageng kai lawẹ ene, Kalelọ, mĕngkai tanaẹ taha; lawe be mapia!"

Sarang keré i Kalelọ tarạ̣e wue, kụ i sire mĕngkatewe nĕmpanaha, hakịlain napalintakubẹ̆. Buhụ́e sasaẹ nĕngkapuḷẹ. Kutẹu sĕngkamalukade i sire saụewe tarạ̣ nanaha, kutẹu sĕngkakakělla kai piạ pontiěng, (manụ pontiěng) nisahedẹ̆ kụ tạ tĕmbọ-e sen, mĕngkatewe nataho su sakaeng e. - Kaí i sire semben tanasasaẹ nauḷ si Nabaḷạ; mĕngkatewe nĕmpanaha, kụ nawoḷeng lai sahĕllo ene. Sarang bauḷẹ̆ e su rěllahe, i Nabaḷạ ĕnnaẹ limintụ nẹ̆kakělla, kụ i rĕdua tahatuari saụewe nahĕngkiwal̨o mĕnsang sombangkewe apa. I Kalelọ simimbang u: "Sombangku e manụ pontiĕng nisahedẹ.."

Sarạeng kerene, i sire mĕngkatewe nẹ̆koạ sakaeng e masahawụsahawụ, hakịu nasue su kaĕunung u ĕlone. Sarang nasuen koa-e, i sire mĕngkatewe nahumbisara, u : "I kitẹ mĕngkate lighạ mẹ̆buạ, ěndạ̣ sakaeng e semben nasuen koạ-e." Kaí i Nabaḷạ e ren madiri, arawe i Araḷung sire pitu e mĕngkate nĕmpẹ̆bera u: "I kitẹ mĕngkate mamundą̣ẹ̆." Sarang i Nabaḷạ tanakarendehẹ̆ manga ipag-e e, tangú i sie namôngken pamamundaḷ ' i sire u : "Mĕntěhang kaělônge, mĕngkate panondo, pělurang d. pakariáhi; i kitẹ mamundal̨e."

Dokeng kaělônge i sire mĕngkatewe nanondon sakaeng e, mase kạ|urange. Arawe i Nabą̣a e su lłikud'i sire nanondo e mĕngkatewe kimui ěllang-e, angkûng-e: "Kumui ěllangku kadiọ, dadolorang tanadekeng: diọko kihie luwi, kĕhúde rą̣ĕnno-utạ; luwiku kihin kanuku, sĕndug' u madiatumpa, d. awíke limu papotokang, samberaun lahẹ̆gitang; iạ buhụe tanaẹ mĕndenọ."

Bọu ene i rĕduan Mẹ̆konda e nẹ̆paparingangke nĕndenọ, kụ sarang su akẹ e, i Nabaḷa e mĕngkatewe nẹ̆bera si Mẹ̆konda: "I kadua 
rembeng mẹ̆tamba mĕndenọ, mẹ̆dĕmmohẹ̆ mĕlaloḷong; demben mĕndenọ su ake mẹlẹ̆lelang, su liwuạ napahiạ; buhụ́ mẹ̆dalaheme luwi, mẹ̆daroḷosẹ bawuha, r. mẹ̆daḷahemẹ lilị." Arawe i Mẹ̆konda e kai simimbang u: "Iạ kai madiri mĕndenọ su akẹ mĕlẹ̆lelang, su liwuạ napahiạ, madirin lěngkụ ionodẹ̆, kundimang ianserẹ̆, madirin monodẹ̆ su apeng, ianserẹ̆ su lighareng, madirin mẹ̆sombang u luạ, mẹ̆saļobạ u rumol̦ong: kawe mĕndenọ su akẹ bangka, liwuạ takumakěndị, kụ buhụ́e mẹ̆daḷhemẹ luwi, mẹ̆daroḷosẹ bawuha, buhụ́e mẹ̆daḷahemẹe lilị d. mẹ̆potọ limu , Nabaḷạ !"

I rĕdua marĕngụ-děngụ su akẹ, hakị hẹ̆do ěllo sen bawa, wuhu narĕnta su wal̦e. Sĕngkakakĕlla e meda e sen kạpapato, kụ i sire napatiral̦ang nẹ̆paparingang kimang. Tangú i Nabạ̦ạ e nẹ̆bera si Mẹ̆konda: "Dembeng mẹ̆tamba kumâng, mẹ̆demohẹ̆ manimokolẹ̆, dembeng mẹ̆pẹ̆di pineda." Sarang bọu kimâng e i Nabaḷa e saụewe nẹ̆bera si Mẹ̌konda: "Demben mẹ̆tamba mĕmama, mĕdemohẹ mẹ̆sělẹ̣pa, dembeng mẹ̆kiki rělling, Mẹ̆konda!“

Bọu ene i Nabalạ e nẹ̆berạe wue: "Mĕnsang pangukahẹ̆ bantang, Mẹ̆konda, pamungkaesẹ̆ bioko, buhụ́e takateng mamundaḷẹ̆. Bọu ene i Nabalạ e nẹ̆berạe lai: "Kamageng itĕntang mamundaḷẹ̆, itunaning mamarasi, panindụ bĕbiren sarạ, podang goghaheng iạ marĕnta. Kumbahang mẹ̆bansị bawěllo, mẹ̆turalị basanalụ, dingạ makạgĕnggang naung, makạpapĕmpang doko." Bọu ene i Nabalı e mĕngkatewe limintụ, ará tanáẹ kutẹ kai kinẹ̆tokang, kaí i sie tawe nẹ̆dian ene, man tanaẹ limintụ. Bawạewe su tumbalatung e o, tumbaḷatung sĕmbua napẹ̆di, kaí i sie man tawe napetọ u manga lawe ĕndạ̣ e, man sasaẹ simake, sumbal̦i i Mẹ̆konda e mĕngkai mạmetọ. Sarang i Nabala nasake, rimasehe tahiti raha, r. palalaheng e naposọ, kái i sire mĕngkatewe něhĕngkasẹ̆ bal̨ango, napatiralang namundaḷẹ. Ené sarang su laudẹ̆ e, i sire kai nihombangeng u wanua maihạ, hakị tawe lighạ nakatingara wanua.

Tangú i Araļung sire pitu e kai piạ kanaung-e mamate si Nabalạ, tangú i sire mĕmpĕgẹ̆gighile si Nabalạ e u i sire mĕngkate mĕmpẹ̆tikị těntaḷang den piạ anging ipẹ̆sẹ̆senggọ e. Kai angkûng i Nabalạ e u: "I kamene tanaẹ e pĕmpẹ̆tikị, iạ e remben managhurihi sakaeng i kitẹ e r. mĕlukadẹ̆ si kaınene." Ené i sire narąieng nahuntikị maraḷennnabẹ̆, i Nabalạ e uté mẹ̆sẹ̆sakaengke sẹ̆sane. Karĕng̣̣ i sire su laudẹ̆ e uaḷụe wulang, kaí i Nabaḷa e man tanẹ̆tẹ̆tikị. Ara sĕntaungke i sire su laudẹ e o, i Aralıung sire mĕngkatewe nanihasan Nabaḷa niapẹ̆tikị. Sarang keré, i Nabaḷạ e měngkatewe nẹ̆tikị, d. i Kalelọ limiu nanguḷing. 
Tangú sarang i Nabaḷạ kạpẹ̆tikịe, tangú i Arạ̦ung sire pitu e mĕngkatewe nẹ̆tatibulu si Kalelọ, nịlahipen sire su ḷaudẹ e, kaí nẹ̆barạuntung u i Kalelọ e tawe nate, u i sie kai nẹ̆timbalong uḷing $u$ sakaeng $i$ sire. Bọu ene $i$ sire mĕngkatewe nẹ̆tatibulu mamate si Nabalạ; sio ěllo i sire mạmate si Nabalạ, kaí tawe nakatẹ̆tị si Nabalạ. Arawe i Nabạ̦a e mang mẹ̆tẹ̆tikị, piạ i sire mạngawulu mạmilị si sie; hẹ̆do su kapuḷo ĕlone i Nabalạ nẹ̆bangung. Sarang i Nabą̣a nẹ̆bangung e i sie mĕngkatewe simohọ naiang, d. nẹ̆bera si sire mĕmpạmate si sie:. "Kamageng i kamene mĕngkawe mapulu mamate si siạ e, pangạ̣ạe kirisẹ̆ku ĕndaị e, buhụ́e i kamene makapate si siạ." Ené i sire mĕngkatewe nangạ̣a kirisẹ̆ i Nabaḷa e, kụ pinanẹ̆ka si sie su kaļisusun sẹ̆bạ-e.

Sarang i Nabạ̣ nate, i Kalelọ e wuhụe ĕndaị simake r. nẹ̆bera: "Be! i kamene kai namate tuhangku e ĕng?" I sire pitu e mĕngkatewe lai nẹ̆tatibulu si sie, kai su rą̧ung u pira ěllo i sire man tawe nakaạ̣a si sie. Ará wọu ene, i sie wuhụe namaḷisẹ̆ si sire, kụ i sire pitu e mëngkatewe nasue nate. Bọu ene i Kalelọ nangạ̣a tuhang-e, nịtataho su tĕntangubẹ̆ e, arawe i sire waḷine nịdarěmmẹ, masé i sie nẹ̆sakaeng nẹ̆suḷe soḷong banua.

Tangú ěndạ̣ piạ i Nabalạ pinate, ene sen dimaloho su naung i Mẹ̆konda e, hakịu i sie nipi. Tangú maluka-ḷukadẹ i Mẹ̆konda e mĕngkatewe kimui si Wĕmbuang, angkûng-e: "Kĕnnangko lintụ pakiwanti, lisadẹ̆ pakitariang, mĕnsang kai kere lunggon tikị, baḷiawan pangangĕnna; i Nabaḷa mĕnsang kai nate tĕngadẹ.." Tangú i Wĕmbuang e mĕngkatewe nakitariang; su tariang e siměhang u i Nabaḷa e mamben nate. Sarang i Wĕmbuang nawaḷ̣ e mĕngkatewe nẹ̆bera: "Iạ sen bọu limintụ nakiwanti, lisadẹ̆ nakitariang; ĕndaung kai kere tụ̣an ipi, bạ̣iawan pangangĕnna: i Kakạku mamben nate těngadẹ̆!"

Tangú tanararĕngụ bọu ene i Kalelọ e naratingken banua. Sarang ĕndạ̣ mạduḷung e, senggọ e sen kinakirạ̦an Mẹ̆konda, r. i sie mĕngkatewe nẹ̆bera: "Kai tamẹ̆saḷan mata, tamẹ̆galisan panutubẹ̆: ĕndaị senggọ, daraung ĕndaị daraung (senggọ), endaị senggọ i Nabaḷạ, daraung i Kakạ-u, Wĕmbuang! "Ará, ĕndạ̣ nawunạ, kutẹu kai i Kalelọ, kụ kate sẹ̆sane. Tangú i Mẹ̆konda rĕduan Bĕmbuang e sasaẹ nanĕnsomahẹ̆ d. nahunsake; sarang nasake, i rĕdua mĕngkatewe nakiwaḷo si Kalelọ: "Iạ makiwal̨on tuhang-u, Kalelọ! makiuḷ u kaḷĕmonanu, mĕnsang i Kakạ-u kai suapa?" Angkûng i Kalelọ u : "Kamageng makiwal̨on Kakạku, manga wawine! makiuḷi i Ką̣ĕ- 
monaku : i Kakạku radẹ natĕntang su ahạ, nạitanạ baḷan humamping ; natanạ nẹ̆tiạ nusa, nẹ̆tatal̨akeh' u paruwe./

Kai i rĕdua tawe nahimang habar' i Kalelọ e, hakịu nẹ̣sạ̣ lại nakiwal̨o su karuasul̨ene: "Iạ makiwą̧on Kakạ-u, Kalelọ, makiụ̣ i Kalĕmonanu, i Kakạ-u kai suapa?" Tangú i Kalelọ e tate nakakalirung, hakịu i sie naụ̣i, d. nẹ̆bera: "Kamageng mĕngkai makiwaḷon Kakạku, makiuḷi i Kalẹ̆monaku : i Kakạku radẹ natĕntang su laudẹ̆, natanạ baḷan badoa; kai natanạ pinate, natĕntang nịbawihua; kate utạ-e kinante, saupang-e kinurai, utạ kinanten Kalelọ, nikurain dapo-dapo (aghidẹ̆); kate nitaho su waḷan epo, niwĕntạ bạ̦an baruạ, epone lohon sasaụ, bawĕntane sasahe utạ, sasaẹ naḷurang su kapaḷẹ̆."

Tangú sarang i Mẹ̆konda nakaringihẹ̆ kerene, mĕngkatewe nẹ̆bera : "Iạ mẹ̆tikị sĕntaung, mangĕnna sĕngkabatiang, mẹ̆tikị mĕndahin epo, mĕngal̦insụ baruạ". Sarang kerene, kụ i Mẹ̆konda mẹ̆tẹ̆tikị e o, i Nabalạ e napaip̣̣e si Mệkonda e u: "I kau mĕngkate tarạ̣ su wal̨e, r. sĕngkarěnta e pangaehẹ̆ $d$. lẹggahẹ̆ pakapia-pia wal̨e $r$. pẹ̆dal̦ĕnsung u kapepe, mase pamĕllọ u lama uhisẹ̆ lohon akẹ, su katěllu hẹ̆bine tiwoi: iạ e sen biahẹ̆." Kutẹu su katěllu hẹ̆bine sĕngkakakĕlla e i Nabaḷa e sen mạiang sene.

Nạun piạ i Nabạ̦a nịpapaten sire su laudẹ̆ e, tangu sarang nidarĕmmẹ $\mathrm{i}$ sire, kai nịsasingkạ $\mathrm{u}$ tingge ratu, kụ ene nangěntud'i tataghuang (i Nabạ̦a e) sarang banua e.

Tangú sarang kerene, i sire tahawawine mĕmpĕbẹ̆bal̦ée su wạ̦e tẹ̆be e; kụ kai sen diọ dạ̦akị. I Nabaḷa e nẹ̆berạe si Kalelọ e u: "I kadua ren mẹ̆koạ bal̦en kitẹ buhu." Tangú sarang i rĕdua nĕmpẹ̆koạ baḷe, mĕngkatewe masahawụ-sahawụ nasue.

Sarang bọuten nẹ̆koạ baḷe, tangú kai piạ kaḷiawo (manụ kaḷiawo) i sire 9 (sio), kụ nĕmpẹ̆bera: "Bal̦enu e, Nabạ̦a! kai wal̨e nẹ̆saḷa, banalanu e tanẹ̆tatahino. Kawe kere su naungku, Nabal̦ạ! pěllọ su ĕndumangku: bal̦enu e pasị su rạ̦eng, ontọ su tatempangeng; ute wuhụ́e sẹ̆bạ baḷen Nabaḷa, banalạen Kalelọ; buhụ́e mẹ̆bawatụ toneng, mẹ̆sasahusu lahumbạ, buhụ́e toneng i wuwenu, lahumbạ i wawinenu, deạke lawahan (pisọ lawaha) pungene, silember'u taniwang-e." Kutẹu i Nabaḷa e kai simimbang u: "Bodang uḷi u i upungku, bẹ̆ken lampuagạku, kaí tạu makahombang-hombang, tạu kai makaěbạ, kai lauḷkang, bawẹ̆ken piạ tau makạĕbạ e."

Kutẹu i Wĕmbuang e kai nẹ̆bera: "Kĕnnangko pẹ̆biling likudẹ̆,

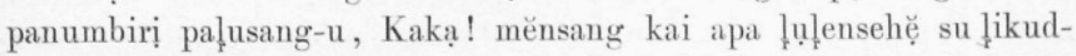
u, sụsaliahẹ̆ su paḷusang-u". Kutẹu i Nabaḷa kai simimbang: 
"Kakẹ̆dị-kakẹ̆dịkona, děmmasẹ̆-dĕmmasẹ̆kona, u kawe wodan pĕllin i upung, doken tělling i lampuagạ: kai weran tau makạbera". Masé i Kalelọ kai nẹ̆bera lai: "Kai kere su naungku, Kakạ! pĕllọ su ĕndumangku, r. kere su ěnnaku e: i kadua ren dumạ̦eng, dumą̧eng mẹ̆deạ kalu, tumempang mẹ̆deạ pato (sakaeng), mẹ̆kĕliwụ dạ̦ukang (sakaeng); buhụ́e mauḷi mamundaḷẹ̆, mĕhabarẹ̆ mamarasi; buhụ́e mẹ̆daḷahaghin tantang, mẹ̆dal̦ahumbạ u wioko (panamba); buhụ́e mẹ̆katạ u wuwe, mẹ̆tabeạ u wawine; buhụ́e mamundaḷẹ̆ mẹ̆bawatụ toneng, mẹ̆sasahusu l̨ahumbạ, Bĕmbuang!" .

Kutẹ i Wĕmbuang e kai nẹ̆bera: "Kamageng kai maụ̣ mamundal̦ẹ̆, mĕhabarẹ̆ mamarasi, Kakạ! panondon pato ḷimpurusẹ̆, daḷukang dalintogarẹ̆". Sarang i Mẹ̆konda nakaringihẹ̆ beran Bĕmbuang kerene, i sie mĕngkatewe nẹ̆bera: "Abe pẹ̆bera kerene, ene kai pato pĕlli, rąukang takasasẹ̆bạ; kụ kawe kere su naungku, Nabalạ! pěllọ su ĕndumangku: kamageng i kau mamben mamundặ̣̣, ute panondon patonu wuḷang, dą̣kang-u kawe raụu (bụ̂ang), bewẹ senggọ-e winawa, daraung-e kawe kĕngkomọ; uḷing-e kawe wituing, taghurihine (uling-e) Pohiama (bituing Pohiama); buhụ́e kasěhụ pamundaḷ̆, kariadi pamarasi; buhụe pangukaheng liri (mamâng), pamungkaěsang siniạ (mamâng), Nabạ̣ạ".

I Mẹ̆konda sạ̣ lai nẹ̆bera: "Iạ makiwawan doho, makisaghĕnnun (makiwawa) pawawa; doho otong su pung-e, sahampi (otong) su taniwang-e; doho onggọ su ratun Balanda, maļamben Kumpania; kutẹu sarang Bạ̦anda kimondọ, Mawĕndo kimakĕndoạ, — ene rohon Mẹ̆konda, buhụ́e kisěhụ pamundaḷẹ̆, kariadin pamarasi, Nabaḷạ!" . Ará, sakaeng i rĕdua tahatuari e nasue, kụ mamundą̣e o, i Wĕmbuang e měngkatewe nẹ̆bera: "Kai kere su naungku, Kakạ, pĕllọ su ĕndumangku: patonu e suḷe, dą̧ukang-u e saụ buạ, sumbaḷ̣ kamal̦irang; iạ kai mạtakụ u woba, mạgiantang u wadoa, ĕndạ̣ boba nahẹ̆pingken senggọ, narĕndungken daraung; i saịe mẹ̆tĕndạ i wuwenu, mẹ̆pąawạ $i$ wawinenu, i sạ̣e mẹ̆tĕndạ u pintu; iạ tumą̧ang suapa, Kakạ? ĕndạ̣ kai monan mangangalo".

Kutẹu sarang i Nabaḷa nakaringihẹ̆ kerene, i sie nẹ̆bera su wawinene: "Iạ kai sumohọ mẹ̆tikị, mẹ̆tikị kai mangĕnna; kumbahang dingạ pukông, arị dingạ bungkaesang; u iạ kai mẹ̆tikị mangĕnna, mangènna mẹ̆sipirẹ̆. Arị matakụ-takụ, Bĕmbuang! giantang aị gaghiantang, takụ liwuhẹ̆ su naung, salłombeng su ĕndumang; ĕndạ̣ monan mĕndaruḷagẹ̆, dumoḷong u mananąupi, kĕnnangko tarạ̣ kasaka su pintu, kairengkang su kĕmbitang, ĕnsangko tẹ̆tatingang senggọ, kĕnnangko pĕmpamatehẹ̆ daraung, ĕnsang senggọ iwunạ 
suapa, ituḷi su wanua sude, mĕnsang senggọ iwunạ su l̦antehẹ̆".

Bọue' i Mệkonda e nẹ̆berạe wue: "Kumui ĕllangku mihinu, darolorang mamamohang: Dakọko kasẹ̆bang su apeng, kailisadẹ lighareng (apeng), mënsang pakiwal̨on mona, pakiuḷi u rumolong: mĕnsang monan mangangalo, rumolong u mĕlạ̣iaha, mĕusang monan mangangalo pintu, mĕlaliaha kĕmbitang." Sarang mihinu sasaẹ nakiwal̨o, kutẹu i sire su sakaeng e kai simimbang: "Kamageng makiwal̨on mona, makiuḷị u ḷumolong, ĕndaung e monan mangangalo pintu, mĕlą̣iaha kĕmbitang; pamile esẹ mapia". Tangú i Nabaḷa d. i Kalelọ e nĕndokạewe pangalo ĕndạ̣ e, kụ nasue nipaten dĕdua, nawaḷi e mang mahạ̦i-haḷi nakatạ̦ang pinamawa uḷị.

Tangú sarang bọu ene, i Nabaḷa děduan Kalelọ e wuhụ́e nasĕhụ namundaḷẹ̆, kutẹu su sĕngkapundaḷẹ̆ ini e i rĕdua e sen tanawaḷ! : u su pamundaḷeng e $\mathrm{i}$ rědua kai nẹ̆bawúno, kụ i rĕdua e nawihua kẹ̆bị. Tangú, sarang i Wëmbuang dëduan Mẹ̆konda nakaringihẹ̆ u i Nabal̨ạ dĕduan Kalelọ kai nate, tangú i rĕdua e mĕngkatewe nĕmpẹ̆tumpate kẹ̆bị.

\section{VERHAAL VAN NABALA.}

Er waren eens twee broeders, de oudste lieette Nabal ra, de jongste Kalelọ en hunne zuster heette Bĕmbuang. De vrouw van N. heette Mệkonda, de zwagers van N. waren met hun zevenen, en die zeven heetten allen Araḷung.

Op zekeren dag zeide $\mathrm{N}$. tot ziju jongeren broeder en tot zijne zwagers: "Wij zullen eens een zeereis gaan maken, heden over acht dagen zullen wij vertrekken." Zijn jongere broeder antwoordde: "Wij zouden een zeereis maken, en wij hebben geen vaartuig!" N. zeide: "Och wat! wanneer negen menschen er aan kappen, zou het dan in acht dagen nog niet afkomen?" Daarop zeide N. tot hem: "Morgen zullen wij een boom omhakken." Van 't aanbreken van den dag af stond $\mathbf{N}$. op en ging zitten op de trap en zeide tot zijn jongeren broeder en zijne zwagers: "Slijpt de bijlen, scherpt de houwers." Toen gingen zijn broeder en zijne zwagers terstond aan 't slijpen. 
Toen zij gereed waren, zeide zijn broeder beneden: "De bijlen zijn reeds geslepen, de houwers zijn gescherpt; er ontbreekt nog maar aan, dat wij op weg gaan." Toen gingen K. en de zeven Araļung's heen om een boom te vellen. En terwijl zij opgingen op den weg, daar overkwam het hun dat een slang dwars over den weg kroop. Toen dat het geval was, keerde K. naar beneden terug, om boodschap te brengen aan zijn ouderen broeder, omdat. dit voorteeken er was.

Terwijl K. de trap op kwam, werd hij reeds ondervraagd door $\mathrm{N}$.; deze zeide: "Ik zal vragen naar de bevinding, mij laten zeggen het wedervaren, wat of uwe bevinding is, Kalelọ." Zijn broeder antwoordde: "Wanneer gij vraagt naar de bevinding, u laat zeggen het wedervaren: mijne bevinding is dat een slang dwars over den weg ging." Toen N. dat hoorde, boog hij het hoofd en zeide daarop: "Ik had het reeds overdacht, reeds is het door mij bepeinsd, het voorteeken is echter goed, Kalelọ!"

Toen ging $\mathrm{K}$. weder op en zij gingen een boom zoeken. Toen zij een Lampawanua-boom gevonden hadden, gingen zij aan 't hakken, maar reeds bij den eersten hak zuchtte er een lĕndu en vloog naar beneden. K. ging het weder zeggen aan zijn broeder. Toen N. hem zag, ondervroeg hij hem en zeide: "Ik zal vragen naar de bevinding, mij laten zeggen het wedervaren; wat is het voor een bevinding?" K. zeide: "Wanneer gij vraagt, wat ik bevonden heb, u laat zeggen wat mij is wedervaren, mijne bevinding is dat een lěndu' zuchtte en naar beneden vloog."

Toen N. dit hoorde, zeide hï weder: "Wanneer het dit voorteeken is, Kalelọ! dan is 't een goed voorteeken." Zijne zuster Bĕmbuang nu hoorde dit en kwam naar buiten en zeide: "Indien het naar mijn oordeel gaat, geschiedt naar mijne meening, zoo zoek een andere boot." Maar N. antwoordde: "Wij zullen ons niet storen aan voorteekenen, Bĕmbuang: voorteekenen dienen om van iets af te houden, voorteekenen zet ik liever achter den rug."

Daarna ging $\mathbf{K}$. weder op en toen hij was aangekomen, gingen zịj terstond aan 't hakken. En ziet, toen hij viel, bogen de takken van den boom zich naar beneden. Toen dit alzoo was, ging K. het weder zeggen aan N. Toen N. hem zag, vroeg hij hem en zeide: "Ik zal weder vragen naar de ontmoeting, mij laten zeggen het wedervaren." K. zeide: "Wanneer gij vraagt naar de bevinding, $\mathrm{u}$ laat zeggen het wedervaren: mijne bevinding is dat de takken van den boom zich naar beneden hebben gebogen." 
N. antwoordde: "Wanneer het dat voorteeken is, Kalelọ, ga dan maar voort met kappen; 't is een goed voorteeken."

Daarop dan ging K. weder op, en zij gingen [den boomstam] bekappen, zoodat hij nog kon omgelegd worden. Toen eerst keerden zij terug naar beneden. Den volgenden morgen nu gingen zij weder op, om verder te kappen, en daar zagen zij dat er een pontiěng (een wit soort van woudduif), die door een roofvogel was gedood en geen kop meer had, juist in de boot gevallen was. Maar zij gingen niet meer heen om N. bericht te geven, zij gingen maar voort met kappen, en de vorm kon nog denzelfden dag naar beneden gesleept worden. Toen de ruwe vorm op het erf was, kwam N. de trap af, om er naar te kijken, en de eene broeder vroeg weder den anderen wat hem wedervaren was. Kalelọ antwoordde: "Ik heb een pontiěng aangetroffen, die door een roofvogel was gedood."

Toen maakten zij de boot maar haastig af, zoodat zij gereed was op den.zesden dag. Toen zij afgemaakt was, spraken zij samen af: "Wij zullen maar spoedig op reis gaan, daar de schuit reeds af is." Doch N. wilde nog niet, maar de zeven Aralıngs zeiden: "Wij gaan maar onder zeil." Toen N. het van zijne zwagers niet kon winnen, stelde hij den tijd van hun vertrek vast: "Duw straks bij 't aanbreken van den dag het vaartuig dan maar af, laad het en maakt het gereed; wij zullen onder zeil gaan."

Des morgens zeer vroeg duwden zij de schuit in zee, haar vervolgens ladende. N. echter, terwijl zij afwezig waren om haar af te duwen, riep zijn slaaf, zeggende: "Ik zal mijn geringen slaaf roepen, mijn geminachten dienstknecht: wil voor mij haarzalf raspen, voor mij afschrapen wat het haar glad makt; mijne haarzalf worde geraspt met de nagels, afgeschraapt met de vingers, en haal mij citroenen af, haal dat, waarmee men 't vleesch rauw bereidt; dan eerst wil ik gaan baden."

Daarop noodigden hij en Mẹ̆konda elkander uit om te baden, en toen zij bij 't water waren, zeide $\mathrm{N}$. tot $\mathrm{M}$. : "Wij zullen te samen gaan baden, gezamenlijk een bad gaan nemen; wij zullen eens een bad nemen in een vertakten stroom, baden in verdeeld water; dan eerst zullen wij na elkaar de haarzalf gebruiken, elkâ̂r afwisselen in 't gebruik van den wrijfsteen en na elkaâr de lilị-plant gebruiken." Maar M. antwoordde: "Ik wil niet baden in een vertakten stroom, een bad nemen in verdeeld water, opdat niet het vuil afgedreven worde, de onreinheid met den stroom worde meegevoerd, opdat het niet aanspoele op het strand, aangevoerd worde 
aan de kust, opdat het niet de golven ontmoete, de baren tegenkome; maar ik wil baden in kuilwater, in diep water dat stilstaat, en dan eerst zullen wij na elkaîr de haarzalf gebruiken, elkander afwisselen in 't gebruik van den wrijfsteen, dan pas na elkâ̂r de lilị-plant gebruiken en limoenen snijden, Nabalạ!"

Een zeer langen tijd waren zij beiden in 't water, zoodat de dag reeds zonk, toen zij te huis kwamen. Daar zagen zij dat de tafel reeds toebereid was en toen noodigden zij elkâ̂r uit om te eten. En N. zeide tot M.: "Wij gaan nog eens gezamenlijk eten, met elkaâr 't maal nuttigen, nog eens de hardgebakken sago breken." Toen zij gegeten hadden, zeide N. weder tot M. : "Wij zullen nog eens gezamenlijk betel nemen, met elkâ̂r sirih kauwen, nog eens de pinang bijten, Mẹ̆konda!"

Daarop zeide N. weder: "Wil de kist ontpakken, Mẹ̆konda, de hoeden uitpakken, daarna zullen ze worden opgezet voor de reis." Hierop zeide N. weder: "Wanneer gij wordt achtergelaten terwijl ik op reis ben, eenzaam achterblijft als ik onder zeil ben, voorzie dan het erf van sarạ's, die eerst zullen vernield worden bij mijne terugkomst, en blaas niet op de fluit des avonds, laat geen fluitspel hooren laat op den dag, het zou het hart in beroering kunnen brengen, de borst doen kloppen." Daarna ging N. de trap af, maar naar beneden gaande, werd hij gewaarschuwd door 't geluid eener huis-hagedis, doch hij gaf er niet om en ging maar naar beneden. Terwijl hij op de trap was, brak er eene trede, doch hij werd niet weerhouden door al deze kwade voorteekenen, maar ging heen en begaf zich aan boord, hoewel M. trachtte hem tegen te houden. Toen N. aan boord was, viel er een bloedregen neer en brak de mast, doch zij haalden terstond de ankers op en roeiden daarop heen. En terwijl zij op zee waren, werden zij overvallen door een hevigen storm, zoodat zij niet spoedig land zagen.

De zeven Arąung's nu hadden 't voornemen om N. te dooden, en zij trachten N. over te halen, dat zij maar zouden gaan slapen, zoolang er nog wind was om mede te zeilen. Doch N. zeide: "Gaat gij maar slapen, ik zal ons vaartuig sturen en over ulieden waken." Zij kwamen ten laatste in vasten slaap, en N. stuurde het schip nog verder alleen. Acht maanden lang waren zij nu op zee, doch $\mathrm{N}$. had nog maar niet geslapen. Maar toen zij een jaar op zee waren, dwongen de zeven Arąlung's N. om te gaan slapen. Daarop ging dan N. slapen en ging Kalelọ langs hem heen en nam 't roer in handen. Toen dan N. aldus in slaap was, vielen de zeven Arąung's 
gezamenlijk op Kalelọ aan en slingerden hem in zee, doch bij geluk stierf K. niet, want hij hing zich aan het roer van hun vaartuig. Daarop vielen zij gezamenlijk N. aan, om hem te dooden; negen dagen lang trachtten zij $\mathrm{N}$. te dooden, maar zij konden $\mathrm{N}$. niet verwonden. N. nu sliep maar door, terwijl zij hem aanvielen en naar hem hieuwen. Pas op den 10den dag stond N. op. Toen $\mathrm{N}$. was opgestaan, ging hij achteruit, zette zich neder en zeide tot degenen, die trachtten hem te dooden: "Wanneer gijlieden mij volstrekt dooden wilt, neemt dan die kris van mij, dan eerst zult gij mij kunnen dooden". Toen namen zij dan Nabaḷ's kris en staken hem in de hartkuil.

Eerst toen N. dood was, kwam Kalelọ weer aan boord en zeide: "Zoo, gij hebt mijn ouderen broeder gedood, niet waar?" Daarop omsingelden de zeven ook hem, maar in eenige dagen konden zij hem toch niet vangen. Daarna echter vergold hij het hun en zij alle zeven stierven. Daarna nam K. zijn ouderen broeder en legde hem in de hut, maar de anderen wierp hij weg, daarop voer hij terug naar zijn land.

Toen N. gedood werd, werd Mẹ̆konda dit in den geest gewaar, zoodat zij droomde. En vroeg in den morgen riep M. Bĕmbuang en zeide: "Wees zoo goed en ga uit, om u te laten waarzeggen, ga naar beneden en vraag om orakel, wat of de droom des slaaps beduidt, het gezicht van den tijd der rust; of $\mathrm{N}$. werkelijk gestorven is." B. liet zich daarop waarzeggen; bij het orakel bleek het, dat $\mathrm{N}$. waarlijk gestorven was. Toen B. teruggekomen was, zeide zij: "Ik ben uitgegaan om mij te laten waarzeggen, naar beneden gegaan om orakel te vragen; het is zooals de droom het verraden, de slaap het geopenbaard heeft; mijn broeder is waarlijk gestorven."

Niet lang daarna bereikte Kalelọ het land. Terwijl hij dichter bij wal knam, werden de zeilen herkend door Mẹ̆konda en terstond zeide zij: "Indien mijne oogen zich niet bedriegen, mijne kijkers het niet mis hebben, komt daar aan het zeil, komt het zeil aan, het zeil, komt daar het zeil van Nabala, het zeil van uwen ouderen broeder, Bĕmbuang!" Maar bij de landing bleek het Kalelọ te zijn en hij was nog maar alleen. Toen gingen M. en B. naar het strand, hem tegemoet en begaven zich aan boord; toen zij aan boord waren, vroegen zij aan Kalelọ: "Ik zal vragen naar uwen ouderen broeder, Kalelọ! mij laten vertellen van uwen meerdere in jaren, waar of uw oudere broeder is." K. zeide: "Indien gij vraagt naar mijn ouderen broeder, vrouwen! a laat vertellen van mijnen meerdere in jaren; mijn 
oudere broeder is daar ginds achtergebleven op de eilanden, is gebleven in de diepte van 't geen nabij is; hij is gebleven om de eilanden te tellen, om de eilanden op te sommen."

Maar zij geloofden het bericht van K. niet, zoodat zij nog eens voor de tweede maal vroegen: "Ik zal vragen naar uw ouderen broeder, Kalelọ, mij laten vertellen van uwen meerdere in jaren; waar is uw oudere broeder?" Toen kon K. 't niet meer geheim houden, zoodat hij 't zeide en sprak: "Wanneer gij blijft vragen naar mijn ouderen broeder, u laat vertellen van mijn meerdere in jaren, mijn oudere broeder is achtergebleven daar in de zee, is gebleven in de diepte van den oceaan; hij is gebleven, gedood zijnde, achtergebleven, vermoord zijnde; slechts zijn haar is afgesneden, zijn hoofdtooi is afgeschoren; zijn haar is afgesneden door Kalelọ, afgeschoren met een wapen; 't is maar nedergelegd in het benedenste van de sirih-doos, onderin gelegd in 't diepste van de pinang-doos, de doos waarin de kam ligt, de bewaarplaats voor hetgeen door het haar gaat, beneden geladen in het schip."

Toen M. dit gehoord had, zeide zij daarop: "Ik ga een jaar lang slapen, rusten gedurende een jaar, slapen met de beteldoos op mijn schoot, onder één sarong rusten met de pinangdoos. Toen dit alzoo was en M. dan sliep, deed Nabaḷa Mẹ̆konda droomen: "Ga maar naar huis en aangekomen, veeg en versier het huis ter dege en stapel kussens op, zet vervolgens een wit bord neer met water gevuld. Bezoek het den derden dag, ik zal dan reeds levend zijn." En zie, den derden dag zag zij N. daar reeds zitten.

Toen N. op zee door hen gedood was en door hen was weggeworpen, was hij opgevangen door een nautilus, en deze had hem (Nabalạ) aan land gebracht.

Daarop dan woonden zij met de vrouwen in het oude huis en dit was reeds een weinig slecht. $\mathrm{N}$. dan zeide tot $\mathrm{K}$. : "Wij zullen ons eens een nieuw huis maken." En toen zij een huis makten, was dit zeer spoedig af.

Nadat zij het huis hadden gemaakt, waren er negen kaliiawo's (kạ̧iawo-vogels), die zeiden: "Uw huis, Nabala , is een verkeerd huis, uwe woning is niet goed. Als het gaat naar mijne meening, Nabalạ! zooals het in mijn hart is, bouw dan uw huis op den weg, steek de palen in op de plaats waar geloopen wordt, dan eerst noem het 't huis van Nabalạ, de woning van Kalelọ, dan eerst volg wenschen op, jaag begeerten na, de wenschen uwer vrouw, de begeerten uwer zuster, haal haar een scheermes van de plaats 
waar 't gemaakt wordt, een lemmet van zijnen oorsprong." N. antwoordde daarop: "Het is nog een spreuk van mijne voorvaderen, een verhaal mijner stamouders, dat niemand dit kan vinden, geen mensch 't kan aantreffen, en er is niemand aan wien 't verhaal is gedåan, dat iemand 't kan vinden."

Toen zeide Bĕmbuang: "Wil u achterom wenden, rugwaarts zien, Broeder, (om te zien) wat of daar klinkt achter uw rug, geluid geeft an uwe achterzijde." N. antwoordde daarop: "Zwijg, zwijg toch, wees stil, wees toch stil, het is nog een verbodsbepaling mijner voorouders, nog een onthoudingsgebod mijner stamvaderen, het zijn woorden van iemand die waarzeggen kan."

Daarop zeide K. nog: "Indien 't gaat zooals 't in mijn hart is, Broeder, zooals 't in mijn gemoed is gelegd, en zooals 't in mijne gedachte is, laat ons dan heen gaan, gaan om hout te zoeken, heen gaan om een vaartuig te zoeken, eene boot te vinden, daarna zullen wij spreken van op reis gaan, zeggen dat wij onder zeil gaan, dan eerst zullen wij met verschillende hoeden pronken, ons allerlei hoofddeksels wenschen, daarop zullen wij afscheid nemen van de vrouw, vaarwel zeggen aan de zuster, en dan zullen wij onder zeil gaan om (uw) wensch op te volgen, na te jagen (uwe) begeerte, Bĕmbuang!"

Toen zeide B.: "Wanneer gij wilt spreken over vertrekken, praten over op reis gaan, Broeder, steek dan af met een hoos als vaartuig, met een waterhoos als schip." Toen Mệkonda B. aldus hoorde spreken, zeide zij daarop: "Spreek niet aldus, dat is een verboden vaartuig, een schip dat niet genoemd mag worden; en indien het ging zooals het in mijn hart is, gelijk het in mijn gemoed gelegd is: wanneer gij volstrekt op reis wilt gaan, zoo steek af met de maan als uw schip, en uw vaartuig zij de maan, hijsch als zeil een wolk, (id. in Sasahara), gebruik als roer eene ster, als stuurriem de Pohiama, dan eerst worde de reis ondernomen, de zeetocht uitgevoerd, dan eerst is 't de tijd van voor den dag halen van sirih, de tijd van 't ontpakken van pinang Nabaḷạ!

Mẹ̆konda zeide nog weder: "Ik wil verzoeken een geschenk medc te nemen, een gave over te brengen; reik een geschenk aan den stam, ga eene gave brengen aan den wortel; geef een geschenk aan den koning van Holland, het hoofd der Compagnie, en wanneer de Hollander zich buigt, de Blanke er onderzoek naar doet, dan is dit een geschenk van Mệkonda, dan eerst worde uwe 
reis volbracht, uw zeetocht uitgevoerd." Toen nu hun vaartuig klaar was en zij op reis wilden gaan, zeide Bĕmbuang: "Indien 't gaat zooals in mijn hart is, oudere broeder, gelijk 't gelegd is in mijn gemoed: breng dan uw vaartuig terug, trek het schip weder op, breng het weder terug; ik ben bang voor de zee, ben bevireesd voor den oceaan, de zee daar is afgesloten van zeilen, verdonkerd van zeilen, wie zal uwe vrouw verdedigen, uwe zuster beschermen, wie zal 't vrouwenverblijf beschermen, waarheen zal ik vluchten, Broeder? het zijn schepen van aanvallers."

En toen N. dit gehoord had, zeide hij tot zijne zuster: "Ik trek mij terug om te slapen, te slapen en te rusten, laat ik niet soms worden gewekt, maak mij vooral niet wakker, want ik ga slapen en rusten, rusten en stil liggen. Wees niet te bang, Bĕmbuang, wees niet te zeer bevreesd, verdrijf de vrees uit uw hart, de angst uit uw gemoed, het zijn schepen van aanvallers, vaartuigen van vijanden, wil opklimmen in het vrouwentimmer, naar boven gaan in het prinsessenverblijf, kijk eens naar de zeilen, beschouwt eens de schepen, waar of de schepen aan wal worden gebracht, naar welk land zij worden gericht, of men de schepen soms tegenover (ons) zal doen landen."

Daarop zeide Mẹ̆konda weder: "Ik zal mijn slaaf den politiedienaar roepen, mijn dienstknecht den omroeper: "Ga uit naar het strand, begeef u afwaarts naar de kust, wil daar eens vragen naar de schepen, u laten zeggen omtrent de vaartuigen, of het schepen zijn van aanvallers, vaartuigen van vijanden, of 't schepen zijn van belagers van het vrouwentimmer, aanvallers van 't prinsessenverblijf." Toen de politiedienaar het aan 't strand ging vragen, antwoordden zij die op de schepen waren: "Wanneer gij vraagt naar de schepen, u laat vertellen omtrent de vaartuigen, dit zijn schepen van beroovers van 't vrouwentimmer, belagers van 't prinsessenverblijf; zoek dappere mannen uit!" Toen streden Nabaḷa en Kalelọ tegen de roovers en zij werden allen door hen gedood; slechts zeer weinigen keerden terug, die ontvluchtten om het bericht te brengen."

Daarna kwam er pas iets van de reis van N. en K.; maar van deze reis zijn zij niet terug gekomen, want op de reis hebben zij elkander gedood en beiden zijn omgekomen. En toen Bĕmbuang en Mệkonda hoorden dat Nabạ̦a en Kalelọ gestorven waren, doodden ook zij zich beide. 


\section{AANTEEKENINGEN.}

Het verhaal van $\mathrm{Nabal}$ a, den Sangireeschen vrijdenker, die de algemeen in acht genomen voorteekenen verwaarloost en minacht, en daardoor zichzelven en de zijnen in 't verderf stort, is door zuiverheid van taal en stijl onder de beste Sangireesche Bio's te rekenen. I $\mathrm{k}$ heb het voorop geplaatst, omdat het belangrijk is wegens het Sasahara dat er in voorkomt. Het behoeft wel niet opgemerkt te worden, dat de wijze waarop de personen van dit verhaal spreken, in de werkelijkheid niet voorkomt; misschien wijst deze eigenaardigheid van dit verhaal er op, dat het eenmaal in poezie heeft bestaan en dat deze tekst de nog overgebleven prozabewerking is. De vertaling der parallel-zinnen was in 't Hollandsch niet altijd mogelijk. Waar zij achterwege gelaten is, heb ik het angeduid.

Tangú, zie Spr. bl. 265. Het is hier een onbeteekenend voegwoord, dat, gelijk Sanskr. atha, in den aanhef even dikwijls geplaatst als weggelaten wordt. - $\mathrm{n}$ ạ un, partikel die het Praeteritum omschrijft en 't gewoonlijk tot Plusquam perf. maakt, Spr. bl. 177. pia is hier het verbum subst. " er is ", met na? 11 er voor "er was", bl. 263. - ta u "persoon, individu“ Mal." "orang", tegenover taumata "mensch, de mensch", Mal. "manusija", in tegenstelling tot andere wezens. Indien de naam der woonplaats zonder genitief-partikel met tau verbonden wordt is deze naam een adjectief en duidt de nationaliteit aan, met de gen. part. bet. het "bewoner van - ", bv. tau Sangihẹ̆ "Sangirees", ta u Tawukang "Taboekanees", taun Sangihẹ e "de bewoners der Sangir-eilanden", taun Taw ukang e "de inwoners van Taboekan ". - i rĕdua, pers. v.n.w. 3e pers. tweevd., bl. 236. tahatuari, over deze bet. van taha, z. bl. 77. De uitdrukking i rĕdua tahatuari bet. dus "de oudere met den jongeren broeder". - iakang. Over dit woord, zie bl. 244. Dergelijke 5e Volgr. VIII 
s a sĕng g a hị-termen zijn veel in gebruik onder personen, die elkaâr dikwijls zien en veel met elkaâr omgaan. Er zijn geen vaste woorden voor, maar woorden als sambe, "bekende" (minder ernstig dan ha pị, "vriend"), taking, "boezemvriend" (tumaking "iemd. uit verknochtheid ook in ongunstige omstandigheden vergezellen") worden er vaak voor genomen. Twee meisjes op Manganitu, die vaak berispt werden om hare langzaamheid, noemden elkan̂r met den sasagĕnggahị-naam Doḷạ, Sasahara van mahawesẹ̆, "vlug". 't Gebruik van deze termen in waarschijnlijk een overblijfsel van een verbodsbepaling (pělli) om iemands naam te noemen. Zie bl. 34. Het hangt dus met 't Sasahara samen. - tuari. Over dit woord, zie bl. 137. - Kalelọ komt in een sasambo voor als Sasahara van be ngk o en bet. dus waarschijnlijk "krom". — ba wine bet. in 't Sang. "vrouw" in overeenstemming met de verwante talen, doch de bawine van een man is niet zijne vrouw, maar zijne zuster. - Bĕmbuang, met de bl. 69 genoemde reduplicatie gevormd van buang. - Mẹ̆konda is waarschijnlijk eene vorming van den gewonen vrouwen-naam Konda. - arenge, van areng "naam", met prou. suff. 3e pers. enkelvoud "zijn, haar naam". - ipagẹ "zwager, schoonzuster", vandaar de bijvoeging esẹ, om "zwager" aan te duiden. Zie bl. 217. mĕngkatewe, samengesteld uit mang, kai, te en be (bue). De gewone bet. is "terstond", doch hier, en op meer plaatsen in dit verhaal, heeft 't de bet. van "maar", zoodat de vertaling wordt: zij heetten maar allen Ara ̦̦ung, die zeven ", — ĕndaị, met volgende e, aanw. v.n.w. "die", zie bl. 242.

Sahĕllo uit sa "een, 'n" en ĕllo "dag ", oudtijds "zon ", zooals blijkt uit zinnen als: ĕllo sen bawa, marange "de zon staat reeds beneden, hoog." De h is hier klinkerscheider. 'Lie verder bl. 41, Noot 1. - m ĕngkatewe is hier in 't geheel niet te vertalen en een zuiver stopwoord. - nẹ̆bera, Praet. Perf. van bera, Fut. mẹ̆bera "spreken", bl. 212. - d. en r. zijn verkorte schrijfwijzen voor het voegwoord dingangu, ringangu, "en". Zie bl. 264. - manga, partikel om het meervoud aan te duiden, bl. 218. - ip a g-e, het woord ip a g ẹ (zie boven), voorzien van 't pron. suff. 3 e pers. enkelv. De ẹ̆, die feitelijk niet tot den stam behoort, komt bij afleidingen nooit in rekening, zie bl. 11, Noot 1. Het lidwoord e is achtergevoegd omdat "de zwagers van hem" bepaalde, reeds vooraf genoemde personen zijn. In zulke gevallen mag het niet ontbreken. Zie bl. 245. - Den of deng, 
afkorting van bodang "nog" is, bij 't Fut. een aansporende partikel, waarmee de adhortatief wordt omschreven. Zie bl. 185. su meng g o "zeilen", Fut. met u m gevormd van s e n g g o "zeil". $\mathrm{ku}$, voegwoord ter verbinding van zinnen, die eenigszins uit elkaar volgen, zie bl. 265. - sarang ini, eigl. "van dien tijd tot nu." Naast sarang komt sarạeng voor, alleen als voegw. gebruikelijk, in de bet. "toen". De stam dezer woorden is sara, waarvan manara "afscheiden", vgl. ook sarạ "grens". De beteekenis van sarang is dan ook "tot aan". Bij de bepaling van een toekomstig tijdstip nemen de Sangireezen dit uitganspunt aan en tellen dan naar zich toe. Sarang ini sio hẹ̆bi vertalen wij met "heden over 8 dagen", omdat de Sangireezen den dag op welken zij tellen ook mederekenen en dus in dit geval zeggen "tot nu toe 9 nachten". Over 't tellen bij nachten, de primitieve tijdrekening naar de schijngestalten der maan, zie Prof. Wilken's verhandeling, B. T. L. V. 1886 , bl. 378-59. — mẹ̆buạ, Fut. met volgend lidwoord heeft hier de beteekenis van onzen Intinitief, Zie bl. 171, 188. De zin bet. dus: "heden over 8 d. is het vertrek." M ẹ̆buạ is eig. "opstaan uit een zittende houding ", doch wordt ook van schepen en groote prauwen gebezigd in den zin van "vertrekken么. - k u te u, verb. voegwoord, zie bl. 267. - tuarine, tuari met pron. suff. $3^{\text {e }}$ pers. enkelvoud. - simimbang, Praet. Perf. van simbang, Fut. sumimbang "antwoorden«.- ma munda lẹ̆, Fut. van den stam pund a lẹ̆ "roeiriem", w. w. vorm "roeien", doch ook "eene kleinere zeereis maken", sumenggo, "een grootere zeereis maken“. - ĕndaị, bijw. van plats "hier (tusschen mij en $\mathrm{u}$ ), hier voor mij (gezegd door iemand, die tegenover een ander staat te spreken)." - ta gesloten vorm van 't ontkenningswoord, omdat het praedicatief gebruikt wordt in den zin van "er is niet". 'Zie bl. 260. — sakaeng is 't algemeene woord voor vaartuig, terwijl voor iedere soort een afzonderlijke naam bestaat. 't Is omzetting voor sakeang (Bul. sasakejan) van sake, Bul. Pak. Sea, Dan. Saw. id. Mong. takoi "beklimmen", dat in 't Sang. "instappen" bet. en verder alleen gebruikt wordt voor "aan boord gaan", en "te paard stijgen". - angk úng of ungkúng (waarschijnnlijk de stam kung met voorslag), "zeide-hij", "zei-hij", gebruikt als men iemands woorden aanhaalt. 't Is een zelfst. n.w. en staat in genitief-verband met 't volgende woord. Ook wordt 't met de pron. suff. verbonden, b.v. kungku, k ung-u, kung-e - pilị (mamilị) "houwen." Volgens 't bl. 
161 gezegde, beteekent pamilikang "plaats waar men een houw zal geven." Hier is 't als abstractum gebruikt, in denzelfden zin als ons "waar 9 mannen zullen kappen", om de omstandigheden aan te duiden - siongkata u, Zie bl. 82. De e is hier geen lidwoord, zij dient slechts als rustpunt voor de stem; om den zin buigzamer, aangenamer voor 't oor te maken. - sarang sio hẹ̆bi "tot 9 dagen lang"; hier versterkt sarang de bet. van 't telwoord, zie bl. 231. — relain, uit den of deng en lai, zie bl. 255. - sahaw "u "spoed, vlugheid", masah. "met spoed, vlug gedaan worden", hier "op een gewenschten tijd afgemakt kunnen worden." De ontkenning ta wordt dikwijls bij 't volgende woord proclitisch gebruikt. - Masé, zie bl. 19 en 267. - si sire, datief van i sire, pers. v.n.w. 3e pers. mvd. diọ ĕllo "(de dag van) morgen", van diọ "klein, weinig" en ĕllo "dag", dus "een weinig meer dag, morgen". — manuwang Fut. van tuwang "omhakken, omhouwen". dokeng kaĕlonge "van af [den tijd] dat men door de zon of den dag getroffen wordt." Met kaĕlônge wordt de tijd vroeg in den ochtend, tegen den morgen bedoeld. 't Woord is gevormd met $\mathrm{ka}$ - en - $\breve{n g} \mathrm{~g}$; de e is waarschijnlijk het bez. v.n.w. $3^{\mathrm{e}}$ pers. enkelvoud. Zie bl. 164 - lonsong is Sasahara van ba liung "bijl." - as a, passieve Imperat. Perf. van mangasa "slijpen", gevolgd door kona, bl. 180, Noot 1. Deze oude vorm van 't huidige $\mathrm{ko}$ zou beter in 't tweede (sasahara) lid van den zin passen. - diọko "eens een weinig", wordt tot verzachting vaak bij den Imperatief gevoegd. - Daar diọ hier bij den Imperatief behoort en voorafgaat, heeft het ko na zich, dat anders achter den Imper. komt. - kumbiwị, Sasah. van asa. - ené, zie bl. 266. - nĕmpangasa, Praet. Perf. mvd. van mangasa. Ieder slijpt zijn eigen bijl, vandaar de meervoudsvorm. Zie bl. 194.

Nasue, Praet. Perf. van sue, masue "op raken, af, ten einde zijn"; als hulpw. w., zie bl. 207. — baw a behoorde eigl. tusschen tuarine en e te staan, omdat bedoeld is "zijn jongere broeder, die beneden d. w. z. buitenshuis, maar nog onder het dak zat". Zie bl. 242. - n a u li i , Praet. Pf. van ma u li i "zeggen" van den stam ulị. Zonderling is de intr. passieve vorm van dit w. w, die eene onwillekeurige handeling uitdrukt. Zie 't bl. 148 bij kumâng gezegde. 't Siauwsch gebruikt mangulị, dat in 't Mang. bet. "herstellen" (trans.). - $\mathrm{u}$ is hier gebruikt bij directe aanhaling. Zie bl. 271. — sen bọu niasa, Praet. Pf. 
van asa. Zie boven. - De bijvoeging van sen bọu maakt den vorm tot een volkomen Perfectum. - kurange, 't Mal. knrang "te kort, te min, ontbreken", met prou. suff. 3e p. e. is de bet. van "er ontbreekt nog maar aan, men behoeft nog maar". Een Sang. equivalent van kurang ontbreekt en daarom is het terecht in de taal opgenomen. - nahundalpengke; Praet, Pf. mvd. van dumaleng "gaan". De meervoudsvormen met malı u* hebben een andere bet. dan die der andere vervoegingen. Zie bl: 215. Aanm. 15. De nadrukwijzer ke is hier in "t Holl. met "toen" weer te geven, daar dit den klemtoon op 't w. w. werpt. Zie hierover bl. 274. - Ara "doch, evenwel", bl. 268. Op bl. 73 is "t ten onrechte "onbekend" genoemd. Zie de toevoegsels en verbeteringen. - tarạ̣e "al opklimmende, bij 't opgaan". Over deze e (nadrukwijzer), zie bl. 274. - kai nitondông. Ka i schildert den toestand, z. v. a. "het gebeurde dat". Nitondông, locaal passief van tondo, tumondo "voortschuiven, kruipen "(als slangen en planten). Het achtervoegsel ĕng heeft hier betrekking op de personen, die door dit voorteeken getroffen worden, het is dus, met $\mathrm{kai}$, 't best te vertalen door "het overkwam hun dat er een slang, enz." Het onverwachte dezer gebeurtenis wordt door kutẹu uitgedrukt. u bij 't passief, zie bl. 189. - namotọ, Praet. Perf. van potọ "snijden", hier overdrachtelijk "dwars kruipen over." Als werkwoord van een verklarenden bijzin, staat het in denzelfden tijd als nitondông. - sasa e. Bij w. w. van "gaan" wordt gewoonlijk door bijwoorden van plaats de richting aangegeven. - tuhang, zie bl. 244. - batụ, zie bl. 269. pią, bl. 263.

Madangeng, Praesens van den intr. pass. vorm van dangeng dumangeng "naar boven gaan, (de trap opgaan)". Sarang met volgend Praesens, heeft de bet. van "op 't oogenblik dat gebeurde" of hier met 't intr. pass. "toen K. haast boven was". Zie bl. 175, 176. Het lidwoord achter madangeng behoort eig. bij ĕndạ̣ en maakt mạdangeng min- of -meer tot een appositie van Kalelọ. - nipakiwaḷong, Praet. Perf. Loc. Pass. van makiwa lo "vragen", eig. "doen geluid geven, doen aankondigen" van den stam baḷo, mẹ̆ba lo "klopgeluid maken om iemands dood aan te kondigen". De achtervoeging van 't suffix-è $11 \mathrm{~g}$ geeft de bet. van "vragen naar, ondervragen", daar 't achtervoegsel op 't object der vraag betrekking heeft. - i, de naamwijzer, verdrijft hier de partikels, die anders tusschen 't passief en den agens staan. 
Zie bl. 192. — niĕbạ, Praet. Perf. Pass. van ĕbạ, maka ĕbạ "vinden, aantreffen", dus "het gevondene" omschrijving in Sasahara, van hombang, stam van makahombang, syn. van makaĕbạ. als zelfst. n. w. gebruikt, zie bl. 217. - mĕnsang, zie bl. 269 . - apạe, apa "wat" met den nadrukwijzer e, die den klemtoon op de laatste lettergreep van a pa werpt. — tak ụ niĕnâng. Loc. Pass. Praet. Perf. van ĕnna, mangënn a "denken, meenen". Over dezen vorm van den $1^{\text {en }}$ pers. Pass. zie bl. 191, 193. Het suffix geeft hier meer de bet. van "denken aan, overdenken", evenals bij 't parallelle nisipirang, Praet. Perf. Pass. van mẹ̆sipirẹ̆ "nadenken". - b u a e n stelt hier 't Sasah. van bọ u voor; of het alleen een vermomde vorm van bo u is of het subst. bu a, met den nadrukwijzer e en de genitief-partikel $n$ is niet uit te maken. In 't laatste geval luidt de vertaling "'t is de vrucht van het door mij overdachte." - Lampawanua, een boom die in verhalen voorkomt als grensscheider. - noghọ Praet. Pf. van moghọ; over dezen vorm, zie bl. 198. - De lĕndu is een kleine woudduif, aldus genoemd naar zijn geluid. - na li i tuhange, hier is het voorzetsel su (of si) weggelaten; 't welk men kan doen, indien het eerste van de beide woorden waartusschen het is weggelaten, op een open lettergreep eindigt, welke dan gesloten wordt. Zie bl. 279. Daar u 1 i een half-gesloten eindlettergreep heeft, mocht het hier eigenlijk niet. — nakaringihẹ̆, zie bl. 115. — mimang, bl. 65. Over de vormen met takụ, zie bl. 193.

Manimbuhung, van timbuhung, zie bl. 126. — sombang en hombang, zie bl. 49 .

Keré, samentrekking van kere en ene, bl. 256. - hakịlain, het redengevende voegw. haki, bl. 270, met het encl. lai en de partikel $\mathrm{n}$, die achter $\mathrm{lai}$ de plaats vervangt van het gewoonlijk achter hakị komende u, bl. 255. - napalintak u bẹ̆, zie bl. 140. Praet. Perf. van mapalintakubẹ̆ "kunnen omgekeerd worden, om te keeren zijn", accid. vorm van mẹ̆paḷintakubẹ̆ "omslaan". $\mathrm{M}_{\mathrm{a}}$ is hier in zijne potentieele bet. gebruikt. Zie bl. 114. De vorm der prauw was zoover af, dat ongeveer een derde deel van den stam was afgehakt tot een vlakke zijde, daarop werd de stam nu neergelegd, om de kiel en het beloop der buitenwanden te maken. - sĕngkamal ukade bevat het pron. suff. $3^{\mathrm{e}}$ pers. enkelvoud. Over den vorm, fzie bl. 82. $n$ is a hedẹ̆, pass. van het gr. w. s a h ed ẹ̆, een roofvogel, kiekendief. De bet. is dus "door een sahed ẹ̆ gedood. - tạt ĕ mbọ-e, 
over 't proclitisch karakter der negatie, zie bl. 260. Ook het ontkennende praedicaatswoord tạ, met half gesloten eindlettergreep, wordt proclitisch gebruikt. - n a h ĕngkiw a lpo, afgeleid van den stam baḷo, mẹ̆baḷo "verkondigen, luiden". De vorm is dezelfde als de meervoudsvorm der um-vervoeging, zie bl. 145. De bet. van mahĕng- (voor mahung-) kiwa lo is eig. "gezamenlijk vragen", zie bl. 154 en 215, Aanm. 15. Een andere vorm met dit voorvoegsel, die buiten de $\mathrm{um}$-vervoeging staat, is $\mathrm{mah} \mathrm{u} \mathrm{mb}$ is a ra, van den stam bisara, "gezamenlijk bespreken, met elkander spreken“. - masue als hulpw.w. Zie bl. 207. - tamakarendehẹ̆; dumendehẹ is "tegenspreken, zijne tegenspraak volhouden, het winnen door tegenspreken." - namôngken, w.w. vorm van den stam pông "grens, maat"; de w.w. vorm is "bepalen, vaststellen"; over ke zie bl. 274. - pamamunda lẹ "tijd ván vertrek", over den vorm, zie b. 93.

Dokeng kä̈lônge "Van af dat het daagden, eene uitdrukking voor "'s morgens zeer vroeg". - su l likud' i sire nanoudo e, woordel. "achter den rug van hen die de prauw afschoven". dadolorang, met redupl. en suff. ang gevormd van dolohẹ (dum.), eig. dus een tijd- en plaatsaanduidend zelfstandig n. w., zie bl. 162. Doch hier is het Sasahara van ěllang. - tanạdekeng, ontk. vorm van 't Praet. Impf. van marekeng, stam dekeng, 't Holl. "rekenen", ta nạdekeng is dus hier Sasah. van kadiọ "gering", dus "die niet geteld wordt, geminacht". sëndugẹ̆ Sasah. van kihi. - madiatumpa, Sasah. van kanuku. Vorm en afleiding van dit woord zijn niet duidelijk. De stam tumpa (tum.) wordt o. a. gebruikt van 't (zich ontplooien en) langer worden van de bloemkolf van de pisang. lets dergelijks is hier misschien van de nagels bedoeld. - diọko bij den Imperatief dient om den Imperatief te verzachten; de eig. bet. van diọ is "een weinig, een beetje", zie bl. 258. — awike, zie over het achtervoegsel $\mathrm{ke}$, bl. 166. - limu papotokang is de fijnste soort van citroenen. - lahẹ̆gitang, als Sasah. woord met 't achtervoegsel ang gevormd (zie bl. 64), van den stam hẹ̆gị, w. w. vorm mĕhẹ̆gị "vleesch rauw, met specerijen toebereid, eten". De reduplicatie makt 't tot een werktuignaam, zie bl. 66 .

Nẹ̆paparingangke, wederkeerige vorm (bl. 99) van maparingang, zie bl. 203. — demben, zie bl. 254. - dëmmohẹ is blijkbaar Sasahara voor tamba. Voor den vorm vergelijke men 
dĕmmung "varkensnest, bestaande uit een samenraapsel van takken, bladeren, gras, enz., voorts ĕmmung "ophoopen" en emong "oprapen" - liwuạ is hier Sasah. voor a ke, doch dit is zeer vrij gekozen, daar de bet. is "diepe plaats tusschen de steenen in eene rivier, maar 't water diep genoeg is om er in te baden." - napahiạ, van den stam hiạ, mamahiạ "verdeelen". Naar 't schijnt hebben napahiạ en mĕlẹ̆lelang van plaats geruild, daar 't eerste niet, 't tweede wel Sasahara is. - mẹ̆dalahemẹ, een wederk. w.w. van den stam hemẹ, de "hampas" van iets, in dit geval van de klapa en limoenen, die worden uitgeperst om de haarzalf te bereiden. De bet. van het w.w. is: "de hampas gebruiken, die een ander heeft overgelaten." — De lili-plant wordt gebruikt om het lichaam mee te wrijven; de bladeren geven dan een weinig schuim af, zoodat zij de plaats van zeep vervullen. - a kẹ bangka "kuil-water", bet. hier stilstaand water, zooals uit 't parallelle liwuạ takumakěndị blijkt. Over dit laatste woord, zie bl. 260, Noot 1. (men verbetere daar kẹd ko in kẹ̆dịko) — kundimang, Sasah. van lëngk ụ "lichaansvuil", is afgeleid van kundi "soort van ongeneeselijke wratten". - mẹ̆salpobạ, Sasah. van sombang, van denzelfden stam, doch met invoegsel al (bl. 151), ongenasaleerd (bl. 30) en met ingeslikten in pl. van nasalen sluiter (bl. 35). dumollong, Sasah. van luạ. Men vergel. du p̦ung "wal, rand, zoom" en mĕndulpung "oprollen", zoodat dumoḷong waarschijnlijk bet. "'t geen zich naar de kust begeeft", - kapapato zie bl. 84. Pato is Sasah. van sakaeng. Ipato is "in een lange rij gebouwd worden", het gr. w. bet. dus iets, dat zich in de lengte uitstrekt", vdr. dat het van tafels gezegd kan beteekenen "in een lange rij aan elkander gezet." - napatiral lang is te vertalen met "terstond". Het is een hulpwerkw. zooals de bl. 207 genoemde. - Ook mẹ̆tamba is hier als hulpw.w. gebruikt, evenals 't Sasah. dĕmmoh ẹ̆ of demoh ẹ̆.

Pangukahẹ̆ bantang "pak de kist uit"; hiermede wordt de groote kist bedoeld, die in ieder Sangireesch huisgezin tot bergplaats van kleeren, enz. dient. De parallel-zin "pak de hoeden uit" duidt aan, dat $\mathrm{N}$. de vroeger gemaakte hoeden naar de plaats van bestemming wil uitvoeren, daar de Sangireezen beroemd zijn voor de hoeden die de vrouwen maken en die ze te Menado altijd gemakkelijk kunnen van de hand zetten. Zij gaan dan ook nooit op reis, zonder eenige hoeden mee te krijgen. - sarạ 
"grens", sara (man.) "afscheiden", zie bl. 40 ; sas a ra "drempel". S a ra worden ook genoemd de jonge, nog niet ontplooide kokospalmbladeren ( $\mathrm{tuwo}$ ), die dienen om aan te duiden dat iets pĕlli is, bl. 54. Door het erf met sara's te omringen, maakt men het dus ontoegankelijk voor anderen.

Podang is een weinig gebruikt syn. van hẹ̆do in de bet. "pas, niet eer dan, niet voordat." De gansche waarschuwing van $\mathrm{N}$. aan M. dient om haar af te houden van verkeer met de buitenwereld. - kinẹ̆tokang "getroffen door 't geluid eener huishagedis (kẹ̆tọ), een dergelijk woord dus als nitondông (zie boven, bl. 341). - tumba latung bet. zoowel "trap" als "trede" palalaheng, zie bl. 65 .

Kanaunge; het meervoud is door 't voorafgaande i sire pitu genoegzaam aangeduid, daarenboven worden de 7 Aralumg's lier als eene eenheid voorgesteld. Over de woorden met ka, zie bl. \$0. Zuivere abstracta met ka, zooals 't bovengen. en kapulu "wil" komen zeer weinig voor. - i pẹ̆sẹ̆seng go is een voorbeeld van een instrumentaal-passief (bl. 95, 103, 209). - maral eng met volgend w. w. bet. "gaandeweg doen, hoe langer hoe meer in een toestand komen"; het kan dus bij de blz. 207 genoemde hulp w. w. gevoegd worden.

Mẹtatibulu, van den stam bulu, met voorvoegsel ti, zie bl. 135. - nẹ̆barạuntung, w. w. vorm van barạuntung, zie bl. 41. - mẹ̆timbalpong, zie bl. 126. - mạmate is een duratieve vorın, die hier de bet. heeft van "trachten te volbrengen, wat 't gr. w. aanduidt", daar hij staat tegenover een vorm met $\mathrm{maka}$ in de potentieele bet, voorafgegaan door eene ontkenning. piạ vóór 't Praesens versterkt de duratieve bet. daarvan, evenals wị met "zijn" doen. Zie bl. 263. - kirisẹ̆ is 't Mal. kĕris. Door invloed van de $\mathrm{i}$ in de laatste lettergreep, is de ĕ ook tot i geworden, in plaats van a, zie bl. 41 .

Dimaloho, Praet. Perf. van dalpho, geredupliceerde vorm van loho. De voorstelling is, dat de droom door de geesten wordt ingegeven. - mipi "droomen" van den stam ipi, is van dezelfde vorming als de bl. 198 genoemde w. w. - kĕnnang is 't Mal. kĕn a n, bl. 280. In 't Sang. wordt het gebruikt om den Imperatief' te verzachten. Ook kan men er den Adhortatief mee omschrijven: "beproef eens". — bal iawa is hier Sasah. van lung go "droom"; de w. w. vorm mẹ̆baḷiaw a bet. "hardop droomen, slaapwandelen", bl. 152. - pangangĕnna, zie bl. 57. 
Mẹ̆galisa, zie bl. 57. - panutubẹ̆, bl. 62, 63. — daraung, bl. 57. - ĕndạ̣ senggo enz. Deze wijze van spreken is niet alleen in versierden stijl gebruikelijk, maar wordt ook in de dagelijksche taal gebruikt. In dit laatste geval ontbreken natuurlijk de Sasahara-termen. - sẹ̆sa, zie bl. 40. - mañĕnsomahẹ̆, een vorm der N. dialekten, voor Mang. mangĕns o mahẹ̆, van den stam somahẹ (vgl. sĕmmạ, soma, sombang, simbah ẹ̣ en simbang, bl. 29), met de bl. 69, № 7 genoemde reduplicatie, sẹ̆nsomahẹ̆. - mahunsake, meervd. van sumake, zie bl. 215. - k k l़̆ $\mathrm{m}$ on a, zie bl. 141. Hier is 't gebruikt als Sasah. van kakạ. — ahạ is een woord voor "de verre kust, die maar alleen in flauwe omtrekken zichtbaar is." - hamping, zie bl. 61. De parellel-zinnen ziju hier niet geheel gelijk. — Wat met "eilanden tellen" wordt bedoeld, is niet duidelijk. Waarschl. is 't een verbloemde uitdrukking voor "op zee gebleven". Paruw e is Sasah. van nusa. Missehien is 't eene vermomming van het woord dat in 't Mal. pulau luidt, met omzetting van de klinkers u-a, vgl. Mal. enz. tuba met Sang. lawuo. — kante, zie bl. 235, saupang, bl. 57. - epone lohon sasa ụ; de pinangdoos is, evenals bij ons volk de tabaksdoos, de bewarplaats voor allerlei kleine voorwerpen, die men medeneemt. - sasahe, als werktuignaam, met reduplicatie gevormd (bl. 66) van sahe, manahe "met een mes langs een liniaal snijden" (de ouderwetsehe wijze van kleeren te snijden) en sumahe "voorbijgaan".

Mĕndahin epo; deze beteldoos bevatte 't haar van Nabala en door haar op den schoot te houden, kwam dus Mệkonda in gemeenschap met hem. Zie Prof. Wilken's verhandeling "Über das Haaropfer, enz." Rev. Col. Intern. 1887, bl. 421, vlgg.

Tingge is de nautilus, die ook in de Middellandsche Zee voorkomt; de tingge ratu is de zoogen. papieren nautilus, die doorschijnend van schelp is. - i tataghuang, zie bl. 283 .

I sire tahawawine, zie bl. 77 . - mẹtatahino, zie bl. 204. - banala, zie bl. 154. - buwe, zie bl. 61. - punge bevat het pron. suff. 3e pers. enk. Pung is "stam" van daar "oorsprong, plaats van herkomst" en van ingevoerde waren "de plaats van waar zij gekomen zijn." Dit punge is het secundaire gr. w. van pungene. In dit geval is er Nederland mee bedoeld. Bodang ulị, enz., deze woorden van Nabala zijn onduidelijk; zeer waarschịnlijk is tusschen $\mathrm{kai}$ en la ulikang de negatie ta weggevallen. 
Kona, zie bl. 180, Noot 1. - mẹdaḷahaghi, wederkeerige vorm van 't gr. w. haghi "soort", met afwijkende bet. Ontrent den zin dezer woorden raadplege men 't bl. 344 aangeteekende.mẹ̆katạ is hier Sasah. van mẹ̆tabeạ; de stam is 't Mal. kata. Andere voorbeelden van Mal. woorden als Sasah. gebruikt, vindt men bl. 59, 63 en 282. — lahumba; over vorm en bet. van dit woord, vgl. bl. 67 , r. 10 v. o. enz.

Kamageng kai maulị, enz. De bet. van Bĕmbuang's woorden is niet duidelijk. Uit de woorden van Mẹ̆konda blijkt, dat ze in ernst bedoeld zijn.

Pawawa, van den stam bawa, is Sasah. van dingo of doho "een geschenk dat men zendt, en wel door het te doen medenemen, (pakịbawa) door een ander" - pintu is het bek. Mal. woord voor "deur". De Sangireezen duiden daarmee aan een prinsessenverblijf in de lucht, zooals dus alleen in verhalen kan voorkomen.

Mihinu is 't Port. marinho; op Sangir duidde men daarnee aan een politie-oppasser, in dienst van den onderwijzer, om de kinderen naar school te jagen. - mang mahal i-hạpi nakatal lang pinamawa $u \underline{l}$ ị is een veel voorkomende nitdrukking in de Sangireesche verhalen, om den afloop van een gevecht te beschrijven.

Sĕngkapundaḷẹ is hier gebruikt in de eerste en oorspronkelijke beteekenis van dien vorm, en wil dus zeggen "bij deze eene maal dat er eene zeereis gemaakt werd", dus "ditmaal". 
VERHA A L V A N I) E N A A P.

In de volgende verhalen (II, a-f.) speelt de Aap eene hoofdrol. $\mathrm{Hij}$ is in de Sangireesche sprookjes de groote leugenaar (zie het verhaal $\Pi$ e, bl. 376 beneden) en bedrieger, die de andere dieren voor zijn dienst gebruikt, ze op alle manieren beetneemt en er ten slotte bijna altijd goed afkomt.

De teksten $\Pi$ Ia-IIf zijn versehillende redacties van hetzelfde verhaal, de eene meer de andere minder volledig. Geen dezer lezingen heeft alle bijzonderheden vereenigd. Пa is reeds in 1869 door Dr. Riedel uitgegeven in zijne verzameling van Sangireesche verhalen en liederen (zie Sang. Sprkk. blz. 4, No. 19), bl. s, No. IV. Met goedvinden van Dr. R. heb ik de spelling in overeenstemming met die der andere teksten gebracht. Deze lezing heb ik vooraan geplaatst, omdat zij de anleiding tot den twist tusschen Aap en Reiger vermeldt, die de andere redacties niet hebben, n.l. 't gezamenlijk planten van den pisang-boom, waarvan de Aap alleen het genot heeft. Deze geschiedenis komt, met eenige verandering in $\mathrm{N}^{\circ}$. VI terug. Op merkwaardige wijze vinden we hierin de trekken van een verhaal, dat zoowel in Japan, als bij de voormaamste volken van den O.-I. Archipel teruggevonden is. Belangstellenden kan ik verwijzen naar Prof. Kern's studie hierover, in de "Actes du Se Congrès International des Orientalistes, tenu en 1889, à Stockholm et Christiania". Leiden, E. J. Brill, 1890, "The Tale of the Tortoise and the Monkey".

Het visschen met een pan tot boot hebben alle 6 lezingen gemeen. Daarop volgt bij a, b, e en f het geval met den Haai, die den Aap van verdrinken redt, door hem op zijn rug naar land te brengen, en die daarna te dicht aan land wordt gelokt en bij de eb sterft. Bij b, e en f volgt dan het tooneel met den Reus, dat met cenige variaties, hierop neerkomt, dat de Aap zich door den Reus laat helpen in 't stuk snijden van den gestorven Haai, den 
Reus wegzendt om water te halen in een bamboe-koker zonder bodem, in diens afwezigheid het vleesch steelt en zich voor de vervolgingen van den Reus zoo goed weet te vrijwaren, dat de Reus ten slotte sterft.

De Reiger is overal de medgezel van den Aap, behalve in e, waar de Aap alleen gaat visschen. In e en $\mathrm{f}$ wordt de Reiger nog voor zijn verraad (dat volgens a niets dan gerechte wraak is) gestraft door 't uitplukken zijner veeren. In d en e komt na 't zinken van de schuit, een tooneel met een poliep voor. In d wint de Aap, in e de poliep den strijd. Over 't algemeen zijn e en f 't volledigst, behalve dat zij 't geval met de poliep niet hebben en 't planten van den pisang-boom niet vermelden.

In de andere verhalen (III-XI) is de Aap niet zoozeer de hoofdpersoon, al speelt hij een belangrijke rol. Bij 't opsporen der herkomst van al deze verhalen, houde men wel in 't oog dat op' de Sangir-eilanden geen apen voorkomen. De vraag blijft dus, of zij van de Filippijnen of nit de Minahasa zijn meegebracht. Het tooneel tusschen den Aap en den Haai is klaarblijkelijk van Indischen oorsprong, zie o. a. Pâncatantra (ed. Kosegarten) IV; Kathâsarit-sâgara X, 97 vlgg.; Jâtaka No 208 en 342. '

De rol, die de Aap in de Sangireesche volksverhalen speelt, is die van den Kantjil in het Javaansche dieren-epos (vgl. bv. hetgeen de Aap met de slang doet, op bl. 359, met Kantjil II, 6, vlgg. van de herziene uitgave), die van den Pĕlanduk in de Maleische dierenfabel, nl. de zwakke, die door zijne slimheid den sterke overwint, welke laatste dan ook evenveel argeloosheid en onverstand, als kracht en woestheid vertoont.

1 Deze plaatsen dank ik aan Prof. liern. 
II $x$.

BEKE PIA I WAHA.

Tangú Waha r. Wahoa i rĕdua hapi mapia. Kutẹu nẹ̆gaghighilẹ nệbaelẹ̆, nisuangeng u wusạ i rĕdua sĕngkalu. Sen narĕnnạe, wusa ene nẹ̆buạe. Sarang nasasạ, Bahoa e man tamakatêng; mĕngkai tumbạu Waha sẹ̆sane kụkâng; Bahoa e tala. Bahoa e man tạ kĕndị-e, ta nẹ̆beran apa; kai i sie semben nakaěnna, u Waha e kai mělẹ̆longong si sie.

Sarang nararĕnna, Wahoa e wuhụe nakareạ hingid-e. Kn̂ng u Wahoa e: "I kadua mělaudẹ̆!" Kûng u Waha e: "Ore, i kadua melaudę." Arawe Waha e man tanakaĕnna, u Wahoa e kai mamalisẹ, busa kawe kinâng a Waha e sẹsane. Ho, i rĕdna nëlaudẹ. Sakaeng-e kahèmpeng, pundals-e kakuahẹ, bal̨ung-e pulingka sĕmbau. Knng n Waha e: "Den mẹ̆bawa peda, i kadua." Knng u Wahoa e: "Maningken tạ peda; i kadua mamundąe." Ho, i rědua sasaẹ. Sarang nịdating $u$ isin saghẹ e, kûng u Waha e: "I kadua kuhạe sasae." "Tala", knng u Wahoa e "sasaeko lai!" Ho, ¡ rĕdua sasaẹ nẹ̆těngkalaudệ, lẹènâng u Wahoa e u Waha e sen tamirating, kumalang. Ho, i rědua rimalẹtọe sene. Bahoa e nauli su Waha e: "Iạ" angkung-e "kai nahutung" — suapan Bahoa é kai nangakal̦ĕ Baha e. Kûng a Waha e: "Tạ peda; bệkâng u apa?" Knng a Wahoa e: "Ensạe su sakaeng e!" Ho, Waha e mëngkatewe nangĕnsạ. Sĕngkaĕnsạ, sakaeng e nabẹ̆ka. Sarang nabẹka, knng u Wahoa e: "I kau wuhụe nakaĕbạ bawaḷisẹ̆, i kau kimâng busạ sẹ̆sanu!" Ho, Wahoa e mĕngkatewe timĕllạ. Kûng a Waha e: "O, Wahoa! iạ diọko tĕllạ sarang duḷunge!" suapan Bahoa e sen tarimaringihẹe. Ho, Waha e mĕngkatewe sụsangi, puhineng u i sie sen sal̦a mate.

Sarang kerenée, kotẹu piạ tangihiang limẹ̆to. Sarang Tangihiang e nakasilo Waha e, kûng-e: "Heute! wuhụe piạ kinạku!" Kûng u Waha e: "Kinaseng, iạ e, kaiso iạ tawẹ gẹ̆siku, tạ ateku, tạ timaiku," Kûng u Tangihiang e: "Gẹ̆sinu e kai suapa?" Kûng u Waha e: "Kai su ruḷunge. I kau mạeng mapulu, iạ diọko 
ĕntudẹ̆ su ruḷunge, ren mangal̦ạ gẹ̆siku." Ho, Tangihiang e mĕngkatewe tarạ̣ nangěntudẹ. Sarang nirating u ruḷunge, kûng u Waha e: "Iạ den mangal̦a gẹ̆siku e; i kau pahẹ̆dọe sini!" Uté Tangihiang e mĕngkatewe nahẹ̆do sene. Kûng u Tangihiang e, u pakal̦ighạ bue, Waha e mangalạ gẹ̆sine. Kûng u Waha e: "Pahẹ̆dóeko laa." Narą̧eng Tangihiang e kinaakal̦eng u Walıa e, kinatehêng, kụ Tangihiang e nate.

II $a$. VERTALING.

VERHA A V A N DEN A A P.

De Aap en de Reiger waren goede vrienden. En zij kwamen overeen een tuin aan te leggen, in welken zij één pisangboom plantten. Na eenigen tijd kreeg de pisang vruchten. Toen zij rijpp waren, kon de Reiger er maar niet van te proeven krijgen, de Aap at er telkens alleen van, de Reiger niet. De Reiger hield zich stil en zeide niets, maar hij had wel begrepen, dat de Aap hem bedroog.

$\mathrm{Na}$ eenigen tijd vond de Reiger pas eene list. De Reiger zeide: "Wij zullen gaan visschen". De Aap zeide.: "Ja, wij zullen gaan visschen." De Aap begreep echter volstrekt niet, dat de Reiger wraak wilde nemen omdat de pisangs door den Aap alleen waren opgegeten. Zij gingen dan visschen. Hun vaartuig was een sago-pan hun roeiriem een pollepel, hun teerkost een jonge klapa-vrucht. De Aap zeide: "Wij zullen een houwer meenemen". De Reiger zeide: "Laten we er maar geen meenemen; laten we nu maar gaan". Toen gingen zij dan naar 't strand. Toen zij de tanden van 't rif bereikt hadden, zeide de Aap: "Laat ons niet verder in zee gaan". "Neen", zeide de Reiger, "laat ons nog verder gaan". Daarop begaven zij zich in volle zee, totdat de Reiger dacht, dat de Aap het land niet meer zou kunnen bereiken met zwemmen. Daar lieten zij dan hun vaartuig drijven. De Reiger zeide tot den -Aap: "Ik" zeide hij "heb honger", waarmee de Reiger den Aap bedroog. De Aap zeide: "Er is geen houwer, waarmee zullen wij de klapa-noot splijten?" De Reiger zeide: "Werp haar tegen de schuit aan!" Toen wierp hij haar er tegen aan. Met dat hij wierp, 
brak het vaartuig. Toen het gebroken was, zeide de Reiger: "Nu hebt gij pas uw verdiende loon gekregen, dat gij de pisangs alleen hebt opgegeten". En daarop vloog de Reiger weg. De Aap zeide: "Ach, Reiger! vlieg met mij als 't u blieft tot aan wal!" waarnaar de Reiger echter niet luisterde. Toen weende de Aap voortdurend, omdat hij haast stierf.

Toen het er aldus mee gesteld was, kwam daar een haai boven drịven. Toen de Haai den Aap zag, zeide hij : "Zoo, nu heb ik pas eens vleesch!" De Aap zeide: "Ik zou opgegeten worden, maar ik heb geen vleesch, geen lever en geen ingewanden." De Haai zeide: "Waar is uw vleesch?" De Aap zeide: "Aan wal. Wanneer gij wilt, breng mij dan even naar land, dan ga ik mijn vleesch halen." Daarop bracht de Haai hem er heen. Toen zij den wal bereikt hadden, zeide de Aap: "Ik zal mijn vleesch halen, wacht gij hier!" De Haai dan wachtte daar. De Haai zeide, dat de Aap zich moest hasten, met het halen van zijn vleesch. De Aap zeide: "Wacht nog een weinig!" Al gaande weg werd de Haai door den Aap bedrogen, hij werd door de eb overvallen, en de Haai stierf.

$\Pi a$.

\section{AAN'TEEKENINGEN.}

Met mẹ̆baelẹ̆ wordt gewoonlijk bedoeld: een rịjsttuin maken, land ontginnen orn er allereerst, in 't eerste jaar, rijst te planten. - têng is een samengetrokken vorm voor temang, zie blz. 27. - sẹ̆sane. Sẹ̆sa wordt in 't Sang. altijd verbonden met de pron. suff., dus "in mijn, uw, zijn eentje". Het is een geredupliceerde vorm van het eenheids-woord sa. - maka ĕnna; dit is de bet. van makạ, die bl. 114, 2a is besproken. - mĕlẹ̆longong is Teg. Tijd, omdat de handeling een tijd lang voortduurt, daar de pisangtros langzamerhand rïp wordt, van boven af beginnende. Doch de onvolm. verl. tijd wordt in 't Sang. altijd door het praesens voorgesteld, met of zonder na un, al naardat het noodig is. De stam longong bet. "dom", mĕl. bet. dus "voor dom houden", of beter nog "dom maken, beetnemen".

Makareạ, zie bl. 115. - hingidẹ̆ "gedachte, raadslag" is 
hetzelfde woord als 't Mal. ingat, doch dit laatste hebben de Sangireezen onnoodig overgenomen in den vorm ingat ĕ , in de bet. van "aan iets denken". - kahuahẹ̣ is een werktuignaam van den stam kuah ẹ̆ (mang.) "roeren". Het is een soort spatel, die voor pollepel dient en den vorm heeft van onze roeispanen. $\mathrm{pulingka}$ is o in de $\mathrm{N}$. lijke tongvallen in gebruik voor Mang. lew ohẹ̆, waarvoor de N. lijke tongvallen ook lew ọ gebruiken. - den bij den Adhortatief, zie bl. 188. - isin saghe, woordel. "tanden der riffen" zijn waarschijnlijk de uitstekende gedeelten der klippen, die bij afnemend water zich het eerst boven water vertoonen. - Het gebruik van suapa in dit verhaal is verdacht, daar het Sang. dit woord niet in betrekkelijken zin gebruikt. Het is waarschijnlijk een Hollandisme, men zie de vertaling. iạ diọko těllạ sarang duḷunge. - eigenlijk: "vlieg mị eens even (woordel. "een weinig") tot aan wal!" Zie over de beteekenissen en 't gebr. van diọ verder bl. 25s. Een aantal woorden, waaronder dulpuge, komen nooit anders dan met het pron. suff. van den $3^{\text {en }}$ pers. voor. Dit heeft dan in de vertaling ongev. de bet. van ons lidwoord, doch de juiste beteekenis is aldus te verklaren. Men denkt zich bv. het vaste land, naast de zee en met deze beide voor den geest, spreekt men van "den wal er van" of kortweg "de wal". Zulke woorden zijn: b u l̦u de "de berg", bal a ne "het dal, de vlakte", u l u ne "(het bergachtige) binnenland", buane "(de) vrucht", akene "(het) sap", pûngene "de stam onder aan", met een dubbelen bezittelijken uitgang. - p u h i n e $n$, zie bl. 269, 270. — sa la bet. "fout, schuld", doch wordt bij w. w. en bijv. n. w. evenzoo aangewend als in 't Fransch "manquer de". - pakalighạ als bijwoord gebruikt, zie bl. 122 en 256. Het voorafgaande $\mathrm{k} \hat{\mathrm{u}} \mathrm{g}$ krijgt door het gebruik van dezen vorm met paka min of meer de bet. van "bevelen", zie bl. 187. kinatehêng is een passieve vorm met 't voorvoegsel ka, 't invoegsel in en achtervoegsel ĕng, van tehe, stam van matehe "droog, laag staand" van 't water, in toestand van ebbe. 
III.

Iạ mẹ̆bion Baha $r$. Wahoa. I rĕdua nẹ̆gaghighilẹ̆ nělaudẹ̆; tangú sakaeng i rĕdua kahĕmpeng, pundale kakuahẹ̆, senggọ-e kakalabẹ̆, palalaheng-e sasusụ, baļung i rĕdua lewohẹ̆. Sarạeng su laudẹ̆, angkûng i Waha: "Iạ kai narou". Angkûng i Wahoa: "Pĕlẹ̆sụe inumang i kadua ĕndaị ; tanaẹ e lẹ̆sụ u palalaheng". Ené mĕngkatewe nanawụ palalaheng, kutẹu tanakatẹ̆tị, kai napẹ̆di. Angkûng i Wahoa: "Tanáe e bẹ̆kan pundą̣̆ ẹ̆." Ho mĕngkatewe namẹ̆kan pundaḷ̆ e i Waha; napẹ̆di kai tawe nakawẹ̆ka. Angkûng i Wahoa: "Ensạe ẹndaị su wiwih'u sakaeng". Sarang i Waha nangěnsạ, ute kahĕmpeng e nabệka, kụ niwonohẹ̆. Sarang nawonohẹ̆, su tatěllạ i Wahoa; arawe i Waha kukalangke su taghal̨oang. Kutẹ piạe tangihiang himaung, kạberane: "Heutẹ, heutẹ, i Waha takụ e kinaseng!" Ankûng i Waha : "Makoạbe kerea, upung! ten ateku r. pẹ̆pusoku kai rala kạbawiting su pahẹ̆pạ!" Angkûng u Tangihiang: "Taraịewe aḷakeng!" Angkûng u Waha: "ho".

Ené mĕngkatewe taraị, i Waha mạiang su tạ̦ẹ̆tug' u Tangihiang. Ené sarạeng sen su saghẹ, angkûng u Tangihiang: "Tumpạe Waha! pangaḷa pẹ̆puso r. ate e; iạ mahẹ̆dọe sini." Angkûng i Waha: "Kẹ! upung; iạ mą̧ĕmmisẹ̆ bue; taraị kai ren maral̦ung; tarạiko we lai ralạ apeng!" Ené tarạ̣e wue Tangihiang. Sarạeng sen su sẹ̆bu' luạ, angkûng u Tangihang: "Tumpạe, Waha, iạ mahẹ̆dọe si'." Ene Waha e wuhụ́e timumpa, kụ mĕngkatewe nawị su kotọ u pahẹ̆pạ d. kạpanuḷadane Tangihiang: "Ene tamai lụhĕntimbalong ateku r. pẹ̆pusoku, upung!" Kụ itẹ̆tẹ̆bọ ene ten manga waes' u kanumpeheng su raung u pahẹ̆pạ. Angkûng u Tangihiang: "Lighạewe ěnnạe, Baha, madirin iạ katehêng." Angkûng i Waha: "Hẹ̆do, hẹ̆doko upung! ọo kai mangą̣a pai riọ mapia." Ene mĕngkatewe kumẹ̆se rumakị su sĕngkalu; mạeng i Tangihiang mangosạ u pakạlighạ, sasimbang i Waha mangkere, u kai mangạ̦a pai riọ kapiânge r. apidẹ dumakị su sěngkalu; kụ mangkere, mangkere, kontin Baha. Napẹ̆pidẹ̆ ten pahẹ̆pạ, sĕngkal̦idodọ sene sarạewen natehe. Ene sarang natehe-tehe, i Waha wuhứe ĕnnáe dimĕllusẹ̆. 
Bọue" nẹ̆bera i Waha si Tangihiang: "I kau takụ nikaakal̦eng , bọu namatakụ kuminạ si siạ; u tawe bẹ̆ke, ta pinintu, ate $\mathrm{r}$. pẹppuso iwẹ̆biting su manga kotọ u kalu, mĕngkawe su ral̦ung u wadang kai ipạngakaḷẹ si kau e, nipaụ̣i tamai kạbawiting su kotọ u manga pahẹ̣pạ, kụ i kau e takụ kinaseng! "Ene Tangihiang e mẹ̆bĕngkasẹ̆ tumaḷang, dadẹ saghẹ sen mạtatĕndạ namara-mara. Ene tatẹe nakareạ hĕngange kụ mĕngkate mĕnẹ̆nalang su lịehe kadodọ.

Bọue' i Waha taraịe sọ̣ong baḷe, mangaḷa aghidẹ ipanguạ Tangihiang: kutẹu kai nẹ̆sombang u Ansuang i rĕdua tahanạ mĕmpangekẹ; kụ dẹ̆dahẹ̆ e kalun bangọ, irụ-e uḷang, pạhurune kambing pẹ̆sĕmbaṇ. Angkûng i Waha: "Kai soḷong a', upung!" Angkûng u Ansuang: "Kai mangekẹ, Baha". Angkûng i Waha: "Mẹ̆deạ apa ren su wanuane, takaĕnâng mĕnsang piạ arau tala; mapia sasaẹko mẹ̆sasimbalako mangua ten tangihiang dadẹ e , upung!" Ene Ansuang i rĕdua tahanạ nikahěluasengke, pirua, kụ mĕngkatewe sasaẹ dingang i Waha, nangua tangihiang. Anạ-e niapẹ̆suḷe nangaḷa kâng, arawe i Waha nĕlẹ̆sụe wowong, kụ kai niapatẹ̆pasẹ̆, tawe nělĕmben kihịe. Ene sarang anạ u Ansuang nasongo, mĕngkatewe nirolohẹ̆ niapanuhụ akẹ, arawe i rĕdua mělẹ̆laghạe kinạ ẹ.

Mĕngkate marĕngụ dariọ nanuhụ akẹ, tatedịe sumongo, angkûng i Waha: "Mĕnsangko tuhúke, anạ e, upung, iạ mĕhapa manga kâng d kinạ tamai, madirin piạ manga asu mĕndotong." Ene Ausuang taraịe nẹ̆tuhụ; kutẹu sĕngkakělla mapenẹ bue, o wowong kawe niapatẹ̆pasẹ̆, lẹ̆sụ-e. Arawe i Waha su likud' i Ansuang mĕnğkatewe kimâng kimâng d. kiminạ apan gẹ̆sine, wọe lĕmbon kinạ d. kâng mĕngkatewe nịtataho su kumbuahẹ̆, bọe' mawi su kotọ u pahẹ̣pạ, kụ nitĕntang kẹ̆tạewen manga ruhine r. kâng mahạ̣i. Ene su kotọ u pahẹ̆pạ, i sie mang kạkânge kakinạe, kạpẹ̆pahimange Ansuang e.

Nararĕnna kadodọ, bẹ̆dị ĕnsaẹ e. Sarạeng sĕngkakĕlla kinạ d. kâng sen nilěmbat' i Waha, nẹ̆berạe: "Be, mahunẹ i Waha kai nangakal̦ẹ̆ e ĕng! hẹ̆do, i kau, mạeng takụ ikasilo, mambeng ipĕndaha isi, ipanẹ̆bu pangilạ." Bọue' i rĕdua tahanạ nĕmpẹ̆kingoke, nanaļemọ e kâng d. manga ruhi nitěntang i Waha. Sarang nasuen kâng e, tarạ̣e nẹ̆kakawilọ su kotọ u pahẹ̆pạ, kutẹu nakasilọe si Waha. Angkûng u Ansuang: "I kau kai rasị e mahunẹ ěng! bọu nangakaḷẹ e, hẹ̆do, i kau!" Ene Ansuang mĕngkatewe nanuwang pahẹ̆pạ lẹ̆lahowokang i Waha. Sarang masandigĕ mahaka, i Waha 
mĕngkatewe rimaki su sĕngkalu, kụ mangkere mangkere. Sarạewen nasue nahaka, mĕngkatewe nẹ̆sasahusu. I Waha mĕngkatewe timalang timalang, ku nakaĕbạ baes' u katiupang, mĕngkatewe naiang se'.

Nararĕnnạe kadio, o Ansuang èndaị e. Sarang nakasilo si Waha, nệherạe: "Heute, i kan takụe ipěndaha isi, ipanẹ̆bu pangilạ!" Angknngben Baha: "Iạ mëngkawe tẹ̆be sì, upung; měnsang katewe waha waḷine." Angkûng i Ansuang: "Kụ kawe mèlẹ̆hapa a", i kau?" "Kai mĕlẹ̆hapa wansị i Wawụ". "Iạ mĕnsangko mẹtiụ ho!" "Balạe! pëberâng!" "Tala, iạ mẹ̆tịnko!" Angkûng i Waha: "Ho, pëtiṇe!" Sarạeng nệtiụ, ten katiupang mĕngkatewe nangiki, kụ Ansuang marasạ̣e, arawe i Waha mĕngkatewe timal̦ang. Sarang nakaĕba tĕmpu, mĕngkatewe naiang se'. Nararĕnna kadiọ, Ansuang bẹ̆dịewe ěndaị. Sarang nakasilo si Waha, nẹ̆berạe: "I kau wọu nangakalẹ̆ si siạ, takụ ipĕndaha isi, ipanẹ̆bu pangilạ". "Iạ mĕngkawe tẹ̆be si', Upung! mĕnsang katewe waha waļine." "Kawe mělẹ̆hapa a ?" "Mĕlẹ̆hapa papehẹ i Wawụ". "Iạ mamehẹko". "Tamĕgěllị, madirin pẹ̉herâng i Wawụ". "Tala, iạ mamehẹọ". "Pamehẹe!" Ene mĕngkatewe namehẹ; tangu nikikịen tĕmpu e, arawe i Waha semben timal̦ang. Sarang nakahombang papěhaseng, naiangkewe se'. Nararěnna kadiọ Ansuang ĕndaịe wue. Sarang nakasilo Waha maiang su papěhaseng, nẹ̆berạe: "Heute, i kau wọu nangakaḷẹ si siạ, takụ ipĕndaha isi, ipanẹ̆bu pangilạ." "Mĕnsang katewe waha waline, Upung! iạ mĕngkatewe tẹ̆be sı'." "Kawe mẹ̆kẹ̆kapú?" "Kai mĕlẹ̆hapa pĕnanintakeng u kaluwaeng i Wawụ." "Mahi, iạ mĕnintako." "Balạe, madirin pẹ̆berâng i Wawụ!" "Tala, iạ mĕnintạko." Angkûng i Waha: "Mạeng takasẹ̆ding, mahịe pẹ̆tĕngkataho!" Ene nẹ̆těngkatahọe. I Waha wọu nangikị u laḷewang, mĕngkatewe timal̦ang. Ansuang mẹ̆kẹ̆kiạmandagẹ̆ makịluka, i Waha tawe nahimang, tarạ mĕngkai tụtalang. Tangú Ansuang e natĕpụe kụ natẹ. Nahẹ̆pusẹ̆.

\section{IIb. VERTALING.}

Ik wil vertellen van den Aap en den Reiger. Deze beiden spraken af om op zee te gaan visschen; hun vaartuig nu was een sago-pan, de riemen waren pollepels, het zeil een keukenwaaier, de mast een bamboe-priem, hun teerkost een jonge klapa-vrucht. Toen zij op zee waren, zeide de Aap: "Ik ben dorstig." De Reiger 
zeide: "Maak dan een gat in ons drinken daar, maak er een gat in met den mast." Daarop trok de Aap den mast nit, doch deze kon er niet door heen steken en brak. De Reiger zeide: "Ga haar dan splijten met de roeispaan." Toen trachtte de Aap har te splijten met de roeispaan; zij brak, maar kon haar niet splijten. De Reiger zeide: "Werp haar dan neer op den rand der boot." Toen de Aap haar neer wierp, brak de sago-pan en zonk. Met dat zij zonk, vloog de Reiger weg; de Aap echter zwom in het ruime sop. Op eens kwam daar een Haai aan, zeggende: "Ziezoo, ziezoo, nu zal ik den Aap opeten!" De Aap zeide: "Hoe zal dat gaan, voorvader: mijn lever en mijn hart hangen daar aan de rizophoren." De Haai zeide: "Wij zullen ze gaan halen." "Goed" zeide de Aap.

Daarop gingen zij naar het strand, de Aap zittende op den rug van den Haai. Toen zij reeds op de riffen waren, zeide de Haai: "Spring af, Aap! haal het hart en de lever; ik zal maar hier wachten." De Aap zeide: "Maar voorvader! ik zal verdriuken; het is daar nog diep; ga nog wat naar 't strand toe." Daarop ging de Haai nog verder. Toen zij reeds in de branding waren, zeide de Haai: "Spring nu af, Aap, ik zal maar hier wachten." Toen eerst sprong de Aap af en klom terstond in den top van een rizophoor, terwijl hij aan den Haai wees: "Daar hangen mijn lever en mijn hart, voorvader!" Datgene nu, waarop liij wees, waren bijen-nesten en dergelijke aan de bladeren der rizophoren. De Haai zeide: "Kom er nu spoedig af, Aap! opdat ik niet door de eb overvallen worde." De Aap hernam: "Wacht, wacht, voorvader, ik wil gindsche krijgen, die wat beter zijn." En dan nam hij telkens een sprong en wipte over naar een anderen boom, en wanneer de Haai hem aanspoorde om zich te haasten, dan antwoordde de Aap steeds hetzelfde, nl. dat hij ginds betere zou krijgen, en wipte dan meteen over op een anderen boom, en aldoor maar zoo waren de leugens van den Aap. Alle boomen ging hij rond, terwijl hij aldoor op de hurken rondsprong, totdat het eb werd. Eerst toen het zeer laag water was, kwam de Aap naar beneden. Daarna zeide de Aap tot den Haai: "Nu is het mij gelukt $\mathrm{u}$ te bedriegen, die mij bang gemaakt hebt, dat gij mij zoudt opeten; want er is geen verhaal of gelijkenis van, dat levers of harten ooit opgehangen werden san boomtoppen; die zitten altijd binnen in 't lichaam; 't was om u te bedriegen dat ik zeide, dat ze daar aan de toppen der rizophoren waren opgehangen, en 
nu zal ik u eens opeten!" Wat nu den Haai betrof: opspringen en wegvluchten - maar vóór hem strekte zich het rif reeds als eene omheining uit, reeds geheel droog zijnde. Toen was hij ten einde raad, en zwom maar heen en weer in een kleinen plas.

Daarop ging de Aap naar huis om een mes te halen ten einde den Haai daarmeê in stukken te snijden, en daar ontmoette hịj een Reus met zijn kind, die gingen hengelen; en humne hengelroeden waren kokosboomen, humne snoeren gumutu-touw, en tot aas hadden zij heele geiten. De Aap zeide: "Waar gaat ge heen, voorvader?" De Reus antwoordde: "Wij gaan hengelen, Aap." De Aap hernam: "Gaat men iets zoeken op de plaats waar het thuis is, dan weet men niet of het er is of niet; laat ons gaan en elkander helpen dien haai daar stuk te snijden, voorvader!" Toen verheugden de arme Reus en zijn kind zich zeer en gingen met den Aap naar het strand, om den haai te snijden. Het kind werd teruggezonden om eten te halen, maar de Aap stak de knoopen van een waterbamboe door, en doorboorde dien geheel en al, zonder den laatsten knoop over te laten. Toen nu het kind van den Reus terugkeerde, werd het daarop terstond uitgezonden om water te scheppen; zij beiden echter kookten met elkatur de visch.

Toen het kind geruimen tijd aan 't water scheppen was en maar niet terugkwam, zeide de Aap: "Ga het kind eens achterna, voorvader; ik zal al dat eten en die visch wel bewaken, opdat geen hond er zich aan kome vergasten." Toen ging de Reus zijn kind achterna, en zag dat de bamboe niet vol kon worden daar hij geheel en al doorboord was. In de afwerigheid van den Reus echter ging de Aap terstond hevig aan 't eten, de spijzen en al het vleesch van den visch, daarop deed hij het overschot van de visch en de spijzen in een mand en klom vervolgens in den top van een rizophoor; hij liet slechts de graten enz. en weinig spijs achter. En in den top van een rizophoor zat hị maar spijze en visch te eten, al glurende naar den Reus.

$\mathrm{Na}$ verloop van eenigen tijd hoorde hij hem aankomen. Toen hij (de Reus) zag dat de visch en de spijzen door den Aap waren opgemakt, zeide hij: "Wel zoo, de Aap heeft dus bedrogen! Wacht maar, wanneer ik u zie, zal ik mijne tanden met uw bloed verven, mijn gebit in uw bloed doopen!" Daarop gingen hij en zịn kind eten; de restjes opetende van de spijzen en de beenderen, overgelaten door den Aap. Toen zij klaar waren met eten, keken zij op naar de toppen der rizophoren, en daar zagen zij den Aap. 
De Reus zeide: "Zoo! zijt gij daar boven, na mij bedrogen te hebben! - wacht jij maar!" Daarop ging de Reus den rizophoor omhakken, waarop de Aap zat. Toen hij haast omviel, sprong de Aap over op een anderen boom, en zoo ging 't steeds voort. Toen zij alle waren omgehakt, gingen zij elkaâr najagen. De Aap vluchtte maar steeds verder, en een wespennest vindende, zette hij zich aldaar neder.

$\mathrm{Na}$ een poosje kwam de Reus daar aan. Toen hij den Aap zag, zeide hij: "Ziezoo, nu zal ik mijne tanden met uw bloed verven, mijn gebit in uw bloed doopen." De Aap zeide: "Ik ben al van vroeger hier, voorvader! misschien was het wel een andere aap." De Reus zeide: "En wat bewaakt gij daar dan?"

"Ik bewaak de fluit van Mevrouw."

"Laat mij er dan eens op blazen!"

"Laat liggen, ik krijg knorren."

"Neen, laat mij blazen!"

"Welnu, blaas dan maar," zeide de Aap.

Toen hij blies, beten hem de wespen, en de Reus leed veel pijn, maar de Aap vluchtte terstond weg. Toen hij eene slang vond, zette hij zich daar neder. Na een korten tijd hoorde hij den Reus daar weer aankomen. Toen deze den Aap zag, zeide hij: "Gij hebt mij bedrogen! ik zal mijne tanden in uw bloed verven, mijn gebit in uw bloed doopen!"

"Ik was vroeger reeds hier, voorvader! misschien was 't wel een andere aap."

"Wat bewakt gij dan?"

"Ik bewaak den gordel van Mevrouw."

"Laat mij hem eens omdoen!"

"Dat sta ik niet toe, opdat ik geen knorren van Mevrouw krijg."

Neen, laat mij hem omdoen!"

"Doe hem dan om!"

Toen deed hij hem om en werd door de slang gebeten; maar de Aap ging op de vlucht. Toen hij een olie-pers vond, ging hij daar zitten. Na een korten tijd kwam de Reus daar weer aan. Toen hij den Aap op de pers zag zitten, zeide hij: "Ziezoo, gij hebt mij bedrogen, ik zal- mijne tanden met uw bloed verven , mijn gebit er in doopen."

"Misschien was het wel een andere aap, grootvader; ik ben hier altijd reeds geweest."

"Wat zijt dan aan 't doen?"

"Ik bewaak het werktuig waarmee Mevrouw zich slank maakt." 
"Kom, laat mij me eens slank maken!"

"Blijf er af, opdat ik geen knorren van Mevrouw krijg."

"Neen, ik ga mij slank maken!"

De Aap zeide: "Wanneer gij niet te verbieden zijt, kom dan hier en ga er in." Toen ging hij er in staan. Na den hefboom vastgebonden te hebben ging de Aap op de vlucht. De Reus smeekte om losgemaakt te worden, de Aap luisterde niet naar hem; hij liep maar voort. Toen stikte de Reus en stierf. - Einde.

\section{II/. AANTEEKENINGEN.}

Inumang i kadua ěndai, hiermede wordt de jonge kokosnoot bedoeld, die zij als teerkost hadden meegenomen. M a nga w i inumang is "jonge kokosnoten af halen, om het water er uit te drinken". Is de honger overwegend bij den Sangirees, dan spreekt hij van mangawị lewohẹ of m. puḷing ka. Voor het eerste doel springt lij roekeloos met de kalapa om, ten minste indien deze niet op zijn eigen erf staat. Het kan hem dan niet schelen, of zij nog te jong is en dus nog geen vleesch gezet heeft, of wel reeds te oud is, om als lew ohẹ gegeten te worden. - nanaw ụ palalaheng, trok den mast uit, n. l. uit den bamboekoker waarin hij staat. - I Wahoa. Over 't gebruik van het persoonaanwijzend lidwoord bij dierennamen, zie bl. 243. - Sarang nawonohẹ̆, su tatĕllạ i Wahoa. Deze construtie is gebruikelijk om aanteduiden dat twee dingen tegelijk gebeuren. Gewoonlijk gebruikt men voor het eerstgenoemde feit ook de constructie met $\mathrm{su}$ en het subst. met $\mathrm{ka}$ van den geredupliceerden vorm gemaakt (bl. S1), dus su kawawonohẹ - su tatěllạ, en die constructie is de beste van de twee. - taghal oang is eig. Sasahara. Het gr. w. loang vindt men terug in de uitdrukking s u l o a ng-e "in volle zee," en in mal loang "wijd" vgl. Tag. luang, Bis. haloag, Bal. loang, Mak. Bug. rowang, Mal. ruwang en 't Sang. loahẹ̆ "ruimte" en lohang "gat." De beste vertaling van taghaloang is dus "het ruime sop." Over tagha, zie bl. 76, 77. heute, uitroep van leedvermaak. - Over tak u, zie bl. 193. kinaseng is eigl. een local-passief, dat hier in plaats van 't 
eenvoudig passief is gebruikt. Zie bl. 190 en 191. Het gr. w. is in 't Sang. kin a "visch." De ingeslikte sluiter staat hier dus voor s (bl. 34), zooals ook blijkt uit Bent. kiuas. De w. w. vorm kumina is in de oorspronkelijke beteekenis "visch eten" en in de tweede plaats "vleesch eten." Voor mẹ̆duk ụ "groente eten "zegt men ook kumina dukụ. — kerea is verkorting van kerapa "hoe?", uit kere "als, gelijk" en apa "wat", dus "als wat?" Zie bl. 27, 248. - upung is een titel, waarmee in de volksverhalen de dieren elkaar veel aanspreken of door de menschen angesproken worden. Is de Sangirees in een omstandigheid, dat hij voor een krokodil vrees moet hebben, dan spreekt hij hem ook beleefd met Upung aan. Dit doet hij ook, terwijl hij eer bewijst aan 't jong van een krokodil, dat hij gedood heeft, het behandelende, alsof het het lijk ware van een mensch die hem nabestaat, en dat, om de ouders van 't dier met zijne daad te verzoenen. Dat noemen van dieren met den naam van "voorvader" is dus een animistisch gebruik. - pahẹ̆pa is de naam van een strandboom (Rhizophora conjugata) in 't Mol. Mal. lola ro geheeten. Deze boomen groeien aan 't strand, in tijd van eb ziet men de wortels bloot, en dus den stam daarop staande.

Sẹ̆bu' luạ (voor sẹ̆bun luạ (de nasaal wordt vóór de l niet gehoord, vgl. bl. 5l) is de schuimstreep die in eene lange lijn langs het strand aanduidt waar de golven breken. - mangosa, verkorting van mangosagẹ̆, zie bl. 27. Men lette op 't gebruik van 't Fut. in een zin als deze, waar wij den onvolt. verl. tijd bezigen. Zie verder bl. 171. - Sĕngkalu "één boom" is hier "een andere boom" zie bl. 233. - Sĕngkalpidodọ is hier onjuist gezegd, want dit bet. "met dat hij hurkende rondsprong"; de bedoeling is (en hiernaar is ook de vertaling gemaakt), k ụ k lpidodo òf sĕngkaḷidodọ sene, sĕngka l̦idodọ sini, — in beter Sangireesch: sĕngka li idodọ pai, sĕngka ḷidodọ ěndaung, "nu daar, dan hier neergehurkt in een boom zich vertoonende". Dit w. w. wordt gebruikt van dieren, die bij het springen nederhurken, zooals de apen doen. - Natehe-tehe zie onder 2. blz. 71 , over de woordherhaling. - $\mathrm{namatak}$ is een Praeteritaalvorm van de vervoeging met $\mathrm{ma}^{*}$, waarbij als grondvorm is genomen patakụ, van mapa(ka)takụ (zie blz. 203 over paringang, mam.) De Imper. van 't Pass. is patakuteko! - sen matatĕnda. Bij de beschrijving der omstandigheden, heeft de schrijver een zeekust als bij Manganitu voor den geest gehad, waar koraal- 


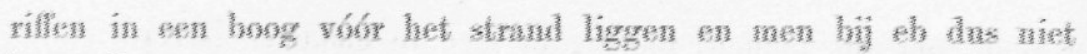

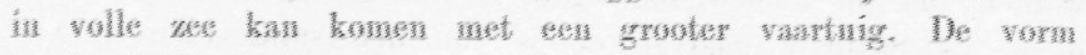

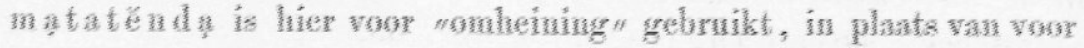
ints dat omheind is.

Ipangna is esn instrumontal mssief, zie bl, 95, 103. - i redua tahana, zie hl, 77 . - mompangeke, nit "t gebrik san "t mwl. blint, dat de heas en zijn Zoon slk van het noodiges visohitug zijn voorien. - kambing pësümban ntelkens een geit", "telkens als or ans noest wonden anngeslagen, was bit sen begle geit," of "ieder sen heele geit, "Voor welke vissehen hit pewzon-visolutuig wel gediend may hebben! - Ka $\mathrm{i}$ solong a'? is des escht Bangiresohe groet, die hungzamerhand door it Skr. Mal. tabea (bl. 185) en 't Mal. siambas, malambae verurougen is. - moga heeft hier weer de bet. van onzen Infintief. - Het tnsschenwerpel pirua (bl. 281) wordt dikwijls gevoegd bij den mam van een persoon van wien men weet dat 't slecht met hem zal alloopen, of war wij mde stakkert" zonden gebruiken. - niknholuaseng is van den stum Inase gevormd met het voorvoegsel hĕ, dat evenals het boven (bl. 354) voorkomende hĕ* in lụh èntimbalong, een meervoudige bet. heeft. Zie nog boven, bl. 341 De passieve voorvoegsels geven aan de uitdrukking de bet. van "door vreugde bevangen over." - tawe nĕlĕmben kihị e. De bamboe-koker, waarin men 't water of zeewater voor dagelijksch gebruik schept, is een bamboe, waarvan alle tusschenschotten doorboord zijn, behalve 't laatste, dat voor bodem dient en dat, evenals de bodem van pannen, potten, vaten en derg. kihị heet, 't welk eigenlijk de zitdeelen aanduidt. - sumongo is hier niet 't juiste woord, daar het "thuiskomen" beteekent. Bedoeld is ma w a li "terugkeeren."

Sĕngkakĕlla, (wowong e) mapenẹ bue - o kawe niapatẹ̣pasẹ̣, lẹ̆su-e. De meest met dezen vorm overeenkomende vertaling zou zijn: "Hij bevond, de bamboe, ja, vol zou ze wel worden, maar de holte (die door het doorsteken van de tusschenschotten nu één, door de geheele bamboe heen, geworden is) had men (of de Aap) dóór laten gaan" — òf: "vol zou ze worden en, men had de holte dóór laten gaan."

I pĕndaha isi, ipanẹ̆bu pangilạ zijn de woorden, die de zoo zeer op menschenvleesch beluste Reuzen der Sangireesche sprookjes spreken, bij 't zien van een mensch of dier. I pèn da ha, Instr. Pass. is gemaakt van den stam daha "bloed", en beteekent: "gebruikt 
worden om (de tanden) bloedig er meê te maken." - ipanẹ̣bu dient als Sasahara daarvan en is van den stam sẹ̆bu, (man) "blusschen." Over pangilạ, zie bl. 56, 65.

Nanuwang pahẹ̣pạ. De Rhizophoren zijn kleiner dan kokospalmen, die de Reus en zijn zoon voor hengelstokken gebruikten; maar het hout is zeer hard. - Baes' u katiu pang. Dit verhaal is het eenige waarin het wespennest voorkomt. In de andere is het, zooals men ziet, de olie-pers die voor de bansị u Waw u fungeert en dit kan, om den vorm, met vrij wat meer succès geschieden. Het brommen van de wespen, 't geluid dat zij maken, is 't eenige dat recht geeft, om 't nest een muziekinstrument te noemen; doch dan heette het nog beter arababu dan bansị, om den vorm en om de muziek. Men zal dus hier wel met eene nieuwigheid te doen hebben.

P ẹ̆b e rân g zou ook kunnen beteekenen : "Gij zult berispt worden," doch uit de andere verhalen en het vervolg blijkt, dat de gegeven vertaling de juiste is. - marasai hier "zeer pijnlijk" en anders "zwaar ziek." Van het Skr. Mal. rasa woord is de zoogen. transitieve vorm tot gr. w. genomen in het Sangireesch. - bẹ̆dị is een woord, dat op allerlei wijzen kan vertaald worden: "ik hoor, ik gevoel, ik bemerk door middel van een der zintuigen." pĕnanintakeng u ka l uwaeng i Waw ụ. Hier ziet men, dat de schrijger de juiste traditie kwijt was, daar hij de gangbare verklaring van de olie-pers al gebruikt heeft bij het wespennest; of hij heeft iets fraaiers, treffenders willen leveren, in ieder geval iets nieuws, door den reus dien dood in de pers te doen ondergaan, in plaats van hem, gelijk in de andere lezingen, te doen verdrinken. - mẹ̆kiạmandagẹ̆ bevat het bestanddeel mẹ̆kiạ. De bet. van mandagẹ̣ is onbekend. 
II $c$.

Tangú piạ i Waha r. i Wahoa. I rĕdua ene kai nẹppaparingang nẹ̆baẹ, kụ simake sakaeng-e kahěmpeng; pundal-e kakuahẹ̆, palalaheng-e sasusụ, daḷimas-e ariru, baḷung-e lewohẹ̆. Tangú sarạeng sen kạpẹ̆baẹe angkûng i Waha: "Iạ kai narou, Wahoa!" Tangú angkûng i Wahoa u: "Lẹ̆sụe lewohẹ̆ ěndaị e." Angkûng i Waha: "Ĕndaị kawe tạ aghidẹ̆, uté!" Tangú angkûng i Wahoa u: "Endaị pělẹ̆sụen palalaheng e." Tangú i Waha e mĕngkate nělẹ̆sụ; kutẹu sarang nělẹ̆sụ, tangú palalaheng e kai napẹ̆di; sarang napẹ̆di, inumang e wodan tanạlẹ̆sụ, angkûng i Wahoa u:

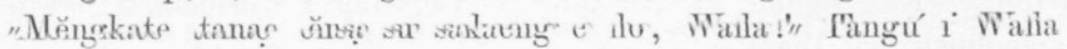
e měngkate tanạ nangĕnsạ. Sarang nangěnsạ, tangu sakaeng i rëdua e nabẹ̆ka, kụ i Wahoa e nakatĕllạ soḷong dụlung-e kụ dimorọ su wowon batu, ku nẹ̆sẹ̆sasisị sẹ̆sane; arawe $\mathrm{i}$ Waha e kụkalang, piruá. Kutẹu sarang nakasilo si Waha ëndạ̣ kạkalange, i Wahoa e kai nẹ̆tendeng kondọ su wowon batu e, mạmanda si Waha e. Tangú sarang i Waha e napĕllọ su rụ̣ung-e, i sie namaringangken Bahoa e angkûng: "I kadua mẹ̆kakutu!" Tangú angkung i Wahoa u: "I kau, kutuang kal̦imona, Waha!" Angkûng i Waha u: "Tala, mapia e i kau 'kutuang kaļimona e." Tangú i Waha e mĕngkate nẹ̆kutu. Sarang nẹ̆kutu, hẹ̆dọewen nangẹ̆do u rukụ i Wahoa e nasuen dệdụl-e. Kutẹu i Wahoa e semben tanakatëllạ kṇ i sie mĕngkate lụlunggi su wowon batu e, batụ sen tạ pauid-e.

Tangú i Waha e měngkate mạiang. Kutẹu i sie nakasilóe piạ apa rụdaḷẹto su raḷung u sasị e; kutẹu kai tangihiang. Tangú Tangihiang e nẹ̆berạe: "Kai apạe kạpia, temang u ate e!" Angkûng i Waha u: "Temang u ate suapa?" Angkûng i Tangihiang u: "Tala! mĕngkate temang u ate mapia", kụ i rĕdua kạpẹ̆bisarane kerene kai wẹ̆ganben dadẹ kai sen kạkohọe, kụ i Tangihiang e kinatehêngke su rạ̣ung u saghẹ e.

Tangú piạe sahiasa wọu ènsaẹ kĕhu e, kutẹu kai i Ansuang. Tangú angkûng i Waha u: "I Upung, i Upung! kai wọu apa!" 
Angkn̂ng i Ansuang u: "Aị tatalewa! mĕngkai pinĕndaha isi, pinanẹ̆bu pangilạ." Angkûng i Waha u: "E, ẹ! abe kerene, Upung! Oọ sasaẹko mangua tangihiang dadẹ e!" Kutẹu i rĕdua e sasaẹ nangua. Tangú kai tạ kâng d. tạ akẹ. Tangú i Ansuang nanuhụe akẹ, kụ nĕlẹ̆sụ bowong e i Waha, kụ niapatẹ̆pasẹ sarang bawa pondoḷ-e. Tangú angkûng i Ansuang u: "Endaung kai tamapenẹ, Baha!" Angkûng i Waha u: "Ene katewe wọu kaḷaļongong-u, waḷinẹbe pandeku tamakapenẹ e; pakalighạ bue mamuhụ akẹ ẹ, iạ e sasaẹ kaḷimona." 'Tangú sarạeng i Waha e tamakakẹ̆dang mahẹ̆do si Ansuang e, tangú e sie mĕngkatewe nawị su kotọ u kalu mararange e, namunin kinạ e.

Kutẹu sarang i Ansuang e kai tanakaĕbạ si Waha e, i sie mĕngkatewe nanahusu; matangga su manga kalu mararangẹ e, mapapẹ̆di; arawe i Waha e sen tẹ̆be mạiang su piạ lakong u katoang e. Kutẹu saráeng i sie mạiang, tangú i sie nakasilọe piạ tau èndaị mẹ̆gongge; arakutẹu kai i Ansuang e. Tangú i Waha e nakiwaļóe: "Kai soḷong apa, Upung?" Angkûng i Ansuang u: "Kai mạnahusu si Waha." Tangú angkûng i Waha u: "Piạ tau susarJ̣pa tarạ̣ kere'." Angkûngben Ansuang e u: "I kau wue, Kạ Baha! kai mẹ̆kẹ̆kapú?" Angkûng i Waha u: "Lạ kai mạapa papehe i Wawṇku." Tangú angkûng i Ausuang u:" Iạ mẹ̆papeheko ringang, Kạ Baha!" Angkûng i Waha u: "Iạ "pệberanģeng i Wawụku." "Tala," angkung i Ansuang "iạ mẹpapehekowe ringang! "

Kutẹ i Waha e nẹggĕllịe si Ansuang e, tangú e sie mëngkatewe naiang su lokong e, ute tĕmpu ene namẹgasẹ si Ansuang e. Kamageng i Ansuang tumalang, těmpu e maĕmma, arawe i Waha e sen timalang, bou nangakalẹ̆ si Ansuang e. Bọue' i sit nakaěbạ mamamĕhasẹ̆ l̦ana, tangú i Waha e nẹberáe: "Pamehoko, i kamene! iạko maměhasẹ̆." Tangú saráeng i sie mệkẹ̆kudidi dạewangeng e, tangú piạewe tau ĕnsae mĕgongge, kutẹu kai i Ansuangke wue. Piạ tĕmbọ-e kinasilọe, tangú i Waha e nakiwalọe: "Upung! Kai soḷong apa, Upung?" Angkûng i Ansuang u: "Mạnahusu si Waha." Tangú angkûng i Waha n: "Piạ tau sasaẹ kere', sụsaḷupa." Arawe i Ansuang e nakiwalọe wue si Waha e: "I kau wue, Ka Baha, kai mẹ̌kẹ̆kapú?"

Angkûng i Waha u: "Iạ kai mĕlẹ̆lukadẹ̆ bansị i Wawụku."

Angkûng i Ansuang u: "Iạ mẹ̆bansịkowe ringang."

Angkûng i Waha u: "Iạ kai 'pẹ̆berangeng i Wawụku." "Tala", angkông i Ansuang "iạ e mẹ̆bansịkowe ringang." Tangú i Waha mĕngkatewe namala; kutẹu sarạeng i sie mẹ̆kẹ̆- 
kudidị, tangú i sie nahepesẹ̆; arawe i Waha e semben nakatą̣ang kạpia, tangú i sie rimal̦eng. Nakĕbạ dano ghẹ̆gerẹ, i sie naiang sene. Sarang i sie mạiang, tangú nakasilọewe piạ taumata ĕndaị mẹ̆gongge; arakutẹu i Ansuangkewe kappia. Tangú i Waha e nakiwaḷ̣e: "Upung! kai soḷong apa, Upung?" Angkûng i Ansuang u: "Kai mạnahusu si Waha." Angkûng i Waha u: "O, kai piạ tau sụsalupa tarạ kere'." "O, i kau wue, Kạ Baha, kai mẹ̆kẹ̆kapura sini e?"

Angkûng i Waha u: "Kai mạhapa pahighin Bawụku."

Tangú angkûng i Ansuang u: "Iạ mĕndenọko wue, Kạ Baha!"

Angkûng i Waha u: "Iạ kai pẹ̆berangeng i Wawụku."

Bọue' i Ansuang e nẹ̆beríe, angkûng: "Kai wọu apa, raralengang-e?"

Tangú i Waha e nẹ̆deạe lentêng, nitalembarẹ̆ kaḷimona, masé nikandang su rano e, tangú wọu ene i Ansuang e tamaje limente. Sarang kạlentene, kutẹu lentêng e kai napẹ̆di. Sarang napẹ̆di, i Ansuang e nanawo su rą̧ung u rano e, tangú i sie nate. Sarang nate, $i$ sie nikinạ $u$ wuala su ralung u rano e.

\section{Nahẹ̣pusẹ̆.}

\section{IIc. VERTALING.}

Er was eens een Aap en een Reiger. Zij hadden elkander uitgenoodigd om te gaan vissehen (met angelsnoeren) en gingen in een vaartuig, hetwelk een sago-pan was; de roeiriemen waren pollepels, de mast een keuken-bamboe-priem, het hoosvat was een scheplepel, de teerkost een jonge klapa-vrucht. Toen zij nu reeds aan 't vissehen waren, zeide de Aap: "Ik heb dorst Reiger!" De Reiger antwoordde: "Maak een gat in die kokosnoot". De Aap zeide: "En er is hier geen scherp werktuig!" Toen zeide de Reiger: "Maak er dan een gat in met den mast!" Toen ging de Aap er. een gat in maken, en toen hij boorde, brak de mast; en toen de mast gebroken was, en er nog geen gat in hun drinken was, zeide de Reiger: "Werp het dan maar tegen de prauw neer". Toen hij het deed, brak hunne prauw en de Reiger ontkwam vliegende, naar land, en zette zich op een steen en ging zichzelven in zijn eentje pluimstruiken, doch de Aap zwom, de stakkerd! Toen de 
Reiger den Aap daar aan zag komen zwemmen, ging hij met 't hoofd in de hand op den steen naar den Aap zitten staren. Toen de Aap aan land was gekomen, noodigde hij den Reiger uit, zeggende: "Laat ons elkander luizen!" De Reiger zeide: "Gij zult eerst geluisd worden, Aap." "Neen", zeide de Aap, "laat gij "t eerst geluisd worden!" Toen ging de Aap aan 't luizen en toen hij het deed, hield hij eerst op, toen de veeren van den Reiger alle uitgetrokken waren. Daar kon nu de Reiger niet meer vliegen, en rolde maar heen-en-weer op den steen, omdat hij geen vlerken meer had.

De Aap nu zat daar maar. Daar zag hij op éens iets in de zee drijven en het bleek een menschenhaai te zijn. En de Haai zeide: "De smaak van lever, wat is die toch goed!" De Aap zeide: "De smaak van welke lever bedoelt ge?" "Ach neen," zeide de Haai, "ik meen maar, dat de smaak van lever goed is" - en aldus met elkander aan 't spreken zijnde, wisten zij niet, dat het reeds an 't ebben was, en de Haai werd binnen de riffen door de eb verrast.

Toen was daar een gedruisch van den kant van 't bosch, en het was de Reus. De Aap zeide: "Voorvader, Voorvader, van waar komt ge?" De Reus zeide: "Maak geen praatjes, ik zal mijn tanden in uw bloed doopen en ze er in blusschen." "Nu, nu, niet zóó, Voorvader! ga mee naar 't strand, dien haai daar snijden!" Toen begaven zij zich naar 't strand en gingen aan 't snijden. Maar er was geen spijs en geen water. Toen ging de Reus water scheppen, maar die de waterbamboe doorboorde was de Aap en hij stak die, geheel en al door, tot het beneden-eind. En de Reus zeide: "Hij wordt niet vol, Aap!" "Dat komt alleen van uwe domheid", zeide de Aap, "aan mijne knapheid ligt het niet, dat hij niet vol wil worden; haast $\mathrm{u}$ wat met water seheppen; ik ga vooruit naar het strand." En toen de Aap het niet kon uithouden op den Reus te wachten, klom hij in de toppen der hooge boomen en . verborg de visch.

Toen nu de Reus den Aap niet kon vinden, zat hij hein achterna, en als hij stootte tegen de hooge boomen, dan braken zij aan stukken; de Aap echter zat al lang bij een gekronkelde slang. Fin terwijl hij daar zat, ontwaarde hij dat daar iemand kwam aanwaggelen, en zie het was de Reus. De Aap vroeg: "Waar gaat gij heen, Voorvader?" "Ik zit den Aap achterna", zeide de Reus. Toen zeide de Aap: "Er is iemand hijgende dien kant op (naar 


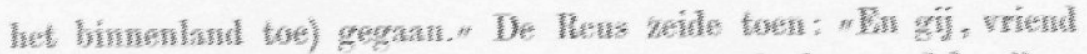

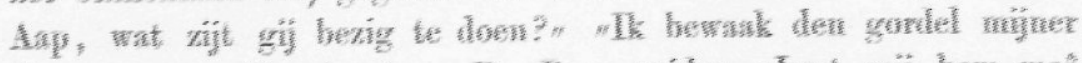

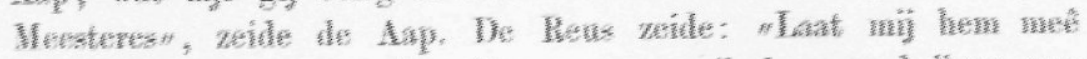

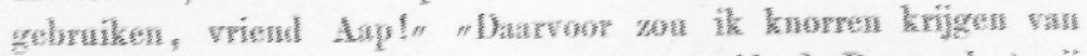

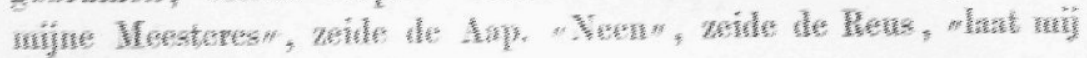
hem ook mar cens ond

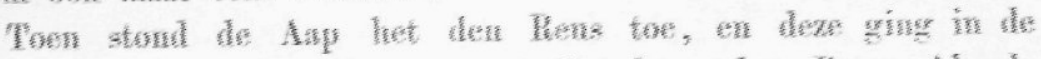
kronksling gitten, en tom wromg lie slang den Neus. Ils de Hens gy de vlueht wille gan, rakte de slang zeh nit; max

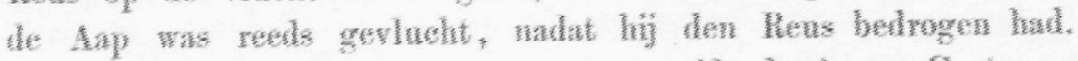

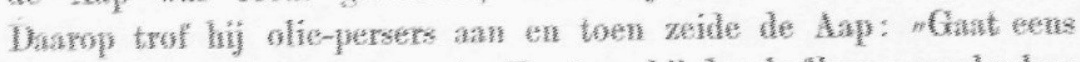
op zij! laat mij eens persen!" Lu toen hij den hefboom zoo kraken ded, kwam dar weer iemand angewaggeld, en het was de lens weer. Toen zijn hoofl te zien was gekomen, vroeg de Aap: "Voorvader, war gat ge heen, Voorvader?" De Reas zede: "lk zit den Aay achterna." - Toen zxide de Anp: "br ging daar iemant ฉú6 heen, hijgende." De leus echter vroeg weer an den Aap: "En gij, vriend Aap, wat doet gij?"

"Ik bewaak de fluit mijner Meesteres", zeide de Aap.

De Reus zeide: "Laat mịj ook eens meê fluiten!"

"Ik krijg er knorren voor van mijne Mevrouw ", zeide de Aap.

"Neen", zeide de Reus, "laat mij ook maar eens fluiten."

Toen stond de Aap het toe, en toen hij den hefboom hanteerde, knelde hij zich; doch de Aap was al weder ontvlucht en had zich op weg begeven. Een groot meer gevonden hebbende, zette hij zich daarbij neer. Terwijl hij daar zat, zag hij weer dat er iemand kwam aanwaggelen, en zie, het was weer de Reus. De Aap vroeg nu: "Voorvader, waar gaat ge heen, Voorvader?" "Ik jaag den Aap na", zeide Reus. De Aap zeide: "Er is iemand hijgende daar naar boven gegaan." "En gij, vriend Aap, wat doet gij hier?"

"Ik bewaak den put mijner Meesteres", zeide de Aap.

"Laat mij eens baden, vriend Aap!" zeide de Reus.

De Aap zeide: "Ik krijg er knorren voor van mijne Meesteres."

Daarop zeide de Reus: "Van welken kant komt men er in?"

Toen zocht de Aap eene brug, maakte daar eerst kerven in, leide die vervolgens over het meer, en daarop ging de Reus er over. Terwijl hij er over ging, daar brak de brug. Toen zij brak, viel de Reus in het meer en stierf. Toen hij gestorven was, werd hij opgegeten door de krokodillen in het meer.

Einde. 
$\Pi c$.

\section{AAN'TEEKENINGEN.}

Mẹpaparingang is van den stam dingang, zie bl. 203. Het is een wederkeerige vorm, met het voorvoegsel pa gemaakt; de bet. is "elkander opwekken tot het gezamenlijk doen van iets, bọete (komaan) zeggen". - mẹ̆baẹ is " uit de prauw vissehen met een hengelhaak (bawa e) ", 't geen bij donkere nachten geschiedt. Men vischt dan met een lang en zorgvuldig gedraaid touw (talin bawaẹ) op groote diepte. Het touw is gewonden op een klos (saḷĕngka). Syn. met mẹ̆baẹ is mĕnoru. In volle zee visschen heet mĕlaudẹ̆. — sasusụ (werktuignaam van susụ, man. "steken, prikken") is een lange priem van bamboe, in het huishouden gebruikt als een één-tandige vork, waarmee men bv. beproeft of het pisang- en batata-kooksel al gaar is, of waarmede men uitpikt iets dat in de pan ligt te bakken. - in umang "drank, drinken", is hier weder de kokosnoot, die als teerkost was meegenomen. - tan a ẹ wordt ook verlofgevend gebruikt, bv. tanaẹ pẹ̆koạ "doe het maar", mĕngkate tanaẹ "ga je gang maar"; hier wijst het de richting naar beneden aan. - mẹ̆sasis ị "zich pluimstrijken, met den bek de veeren in orde brengen" is een wederkeerige vorm van den stam sis i (man.) "luizen tusschen de vingertoppen vangen." De bet. is dus reflexief geworden, doordat het alleen van vogels wordt gebruikt en deze dieren niet, zoosls de apen, elkander luizen, maar zichzelf helpen. Daarom brengt dit den Aap op het denkbeeld van mẹ̆kakutu, dat naar vorm en bet. wederkeerig is. - dẹ̆duḷ-e, zie bl. 217.

Sahiasa is de naam van een onbestemd gedruisch, dat hier de nadering van iets groots aankondigt. - o o is een aanwijzende partikel en komt veel voor met de woordjes pai, ĕndaung, dade, enz. Alleen voorkomende beteekent het "hier" ("als 't u belieft, daar hebt ge ' $t$ !"). Doch hier heeft het niet de juiste plaats in den zin. - manuhụ (suhụ) ake is "waterscheppen, door het vat tegen den stroom in te bewegen"; het doet denken aan suhudẹ̆ "duwen". - - mararangẹ ; over den meervoudsvorm der bijv. n. w. zie bl. 68,225 . - mapapẹ̆di is een frequenta5e Volgr. VIII. 
tieve vorm "in kleine stukken breken", zie bl. 197. - su piạ lokong u katoang, bet. "bij de kronkeling van een reuzenslang" Lokong is een enkelvoudige winding (bv. een hoepel), lakung een meervoudige (bv. een spiraal, opgerold touw), zie bl. 28. Over su piạ, zie bl. 278. - Ka, een titel waarmee alleen de Aap in de sprookjes wordt genoemd. Zonder twijfel is dit woord identisch met het oude M. P. woord voor "oudere broeder", dat bv. in 't Jav. raka luidt, van den stam ka '. In 't Sang. heeft 't gewoonlijk den vorm a kang, zie bl. 35 , noot 1 en bl. 244. pẹ̆berîngeng heeft het achtervoegsel ĕng (stam bera), maar daar het voorvoegsel $\mathrm{i}$ is weggelaten, heeft ang zijne eigenlijke kracht verloren en wordt als teeken van 't passief beschouwd (bl. 190), zoodat men, om er een locaal-passief van te maken, er nog eens -eng achtergevoegd heeft.

Mẹ̆gĕllị in den zin van "toestaan", is een Malayisme. Ook mangonggo vindt men soms in die bet. Het juiste woord is bala (mam.). - mẹ̆kẹ̆kudidị is een grappig woord, op goed geluk af gevormd, om het zacht knarsend geluid na te doen, dat de Aap met den hef boom der olie-pers maakt, bij 't hanteeren. mẹgongge is de Teg. Tijd van den stam ongge en is met klankverandering gevormd van ing ge, om eene forschere beweging aan te duiden, zie bl. 27, 198.

Nitalembarẹ̆ is vertaald in overeenstemming met nikal lentabẹ van de andere redacties, een frequentatieve vorm van kentabẹ̆ "kerf", dus: "werd op verschillende plaatsen gekorven". Tembarẹ̆ is overigens aan Mej. Steller niet bekend. - Bij de antwoorden van den Aap sasae (taraị) kere' denke men zich, dat hij met den vinger wijst in de aangeduide richting; dit blijkt uit de bijvoeging van kere'.

Daralengang "de weg dien men, waarlangs men gaat" naast dalpeng, dat eenvoudig "weg" beteekent.

1 Vgl. Kern «Klankverwisseling in de M. P. talen, B. T. L. V. 1887, bl. 334. 
Kutẹu i Wahoa kai namaringang i Waha nẹ̆baẹ. Tangú i Waha napulu wue, kụ sakaeng i rĕdua e kahĕmpeng, pundaḷ-e kakuahẹ̆, senggọ-e kakalabẹ̆, palalaheng sasusụ, balang-e ariru, kai tawe aghid' i rĕdua. Sarang i Waha napulu mẹ̆baẹ, angkûng i Wahoa u: "I kau Waha, pẹ̆deạko pahurun kadua." Angkûng i Waha u : "Pahuru apa, mapia?" Angkûng i Wahoa: "Pahuru komang, tawe lighạ mą̧uku." Tangú i Waha e sasaẹe nẹ̣deạ komang, arawe i Wahoa nẹ̆deạewe pakakas'u sakaeng, bọue' nanadia wawaẹ, bọe' sasaẹ nanondon sakaeng i rĕdua. Tangú i Waha narĕntạe, woue' nẹberáe si Wahoa, angkûng: "Sasaee, i kadua ěndaị sen piạ pahuru." Katen kapebaee, i Waha kawe narou, kaiso pisa lalang i rölas

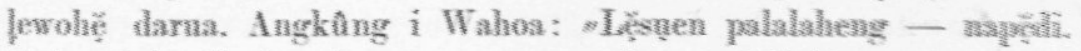

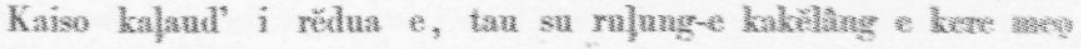
kasariane. Angking i Waha u: Fulaj kai napidi. Say mangsha

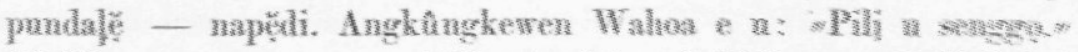
Nipiliewen sengge - naghöle. Angkung i Waha u: mali is hai

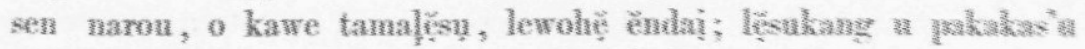
sakaeng, o rndai kai sen nasme nagholo. Augkme i Ushos nz "Bnsae sn sakaeng e," Tangú i Ka Baha müngkateme matsomend su sakaeng $e$, knten sakaeng kai nabeka, u paming kai saksacag kahěmpeng, ku kai kinoa bọ lẹtho èntama makẹti. Tangî sarang manga pakakas' n sakaeng kai nasue nagholo, d. sakaeng kai nabẹka, tangú i Wahoa e nakatella, arawe i Waha e kai kimslangSarang napëllo su saghe, kuten i sie kai rimarisị sa wowron bata.

Tangu su watu ene kai pia baes'n kuhita. Lué samg kuhita e kai suměbang mẹ̆des kâng-e, tangú kai kinasilon Baha e, ku nỉpakele, knten wisi-e èndạ pinamakelĕ e kai nilawung u lauen knhita e. Boue' i Waha e sau namakel'n wisi-e sĕmbẹka, kuten kai say nlawung $n$ hamen kuhita e, tangú kahita e kai tanae mavaleas.

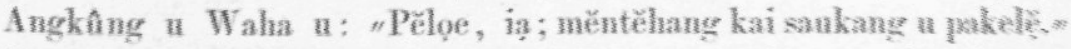
Tangu i Waha e san namakelẹ, kuhita san nëlawng, boue man tanae kabolenge. Tangú i rèdua man kapèbawolenge. Tang̊̃ i Waha 
saụewe namakel'u sĕmbẹ̆ka. Kutẹu kuhita e man kạpamolenge tanaẹ. Arawe wisị i Waha e ute sen nasue pinamakelẹ kuhita e, kụ sen tạ kuat-e i Waha mamoḷeng u wadang-e, tangú i Waha e tanaẹ e naurung su sasị, kụ mậĕmmise. I sie mĕngkate mạngiki mạngiki hamen kuhita pinĕlawung si sie e. Kụ i rĕdua man mẹ̆kẹ̆kakiki su lphang u watu, waes'u kuhita e, tangú hamen kuhita e nadehọ nasue nawawẹssụ, kěkikiang u Waha e. Kụ sarang kạkawẹ̆sụe hamen kuhita e, i Waha mang kạkinạe, tangú kuhita e nadehọ nate.

Tangú i Waha nakakalangkewe kạpia soḷong duḷunge r. kuhita e niwawạen tataghuang, kụ nitongkạ kinạ-e. Arawe kasarian kuhita ene, uté těmbọ-e kere wangọ gaghuwạ sĕmbaụ; kutẹu kinapaten Baha sumbaḷi u i Waha sen mạlěmmisẹ̆; kụ kai tanẹ̆koạ akal̦-e taghaḷẹ nangiki nangiki u kuhita e, ute angkêng i Waha e nate. Arawe i Wahoa ute piạbe panid-e kụ nakatěllạ bue.

\section{II $\pi$. VERTALING.}

De Reiger noodigde eens den Aap uit om te gaan visschen. En de Aap gaf daaraan gehoor en hun beider vaartuig was een sagopan, de roeiriem was een pollepel, het zeil een keuken-waaier, de mast een bamboe-priem, een andere roeispaan was een scheplepel, maar zij hadden geen scherp werktuig. Toen de Aap genegen was om uit visschen te gaan, zeide de Reiger: "Ga gij, Aap, eens aas voor ons zoeken!" De Aap zeide: "Wat voor aas is goed?" De Reiger zeide: "Komang-krabben; dat gaat niet spoedig van den haak af." Toen ging de Aap naar de kust, krabben zoeken, maar de Reiger zocht gereedschap voor de prauw, maakte daarna het vischtuig gereed, en duwde daarop humne prauw in zee. Daarop kwam de Aap thuis en zeide tot den Reiger: "Laat ons nu naar 't strand gaan, er is al aas." Terwijl zij nu aan het visschen waren, kreeg de Aap dorst; doch zij hadden als teerkost twee jonge klapa's meê. De reiger zeide: "Steek ze door met den mast" - deze brak. Zóó ver nu waren ze in zee, dat de menschen op den wal voor het gezicht zoo groot waren als katten. De Aap zeide: "Hij is gebroken!" $\mathrm{Nu}$ nam hij de roeispaan - zij brak. Weder zeide de Reiger: "Houw ze met het zeil open!" Hij hieuw 
weer met het zeil — het scheurde. De Aap zeide: "Ik gevoel mị dorstig, en nu kan ik die klapa niet doorgeboord krijgen: er een gat in maken met de gereedschappen der prauw, - en alles is vernield!" De Reiger zeide: "Werp ze op de prauw neer!" toen wierp vriend Aap ze op de prauw neer en daar brak de prauw, aangezien die prauw een sago-pan was, en gemaakt was van harde klei-aarde. En toen het gereedschap der prauw geheel en al was te loor gegaan en de prauw gebroken was, ontkwam de Reiger door te vliegen, maar de Aap zwom. Toen hij aan de riffen gekomen was, ging hị op een steen staan.

In dien steen nu was het hol eener poliep. En toen de poliep naar buiten wilde komen om voedsel te zoeken, zag de Aap haar en gaf hij haar een trap, en toen werd zijn been waarmede hij den trap had gegeven, omstrikt door de vangarmen der poliep. Daarna gaf de Aap weer met een ander been een trap, en toen werd dat been weder omwonden door de vangarmen der poliep, en de poliep trok hem naar beneden. De Aap zeide: "Laat mij los, of ik schop straks weer." De Aap nu schopte weer, de poliep omstrikte hem weder en trok hem telkens verder naar beneden. Toen trokken zij elkander wederkeerig. En weder schopte de Aap met één zijner pooten. De poliep echter bleef maar naar beneden trekken. Doch de Aap had reeds met al zijne pooten de poliep geschopt en hij had geen kracht meer om zijn lichaam terug te trekken, en toen raakte de Aap onder water en verdronk haast al. Hij beet maar aldoor de vangarmen der poliep, waarmede deze hem omstrengeld had. En zij beiden beten elkander, in het gat van den steen, het hol der poliep, en de vangarmen der poliep gingen ten laatste geheel en al stuk, door het bijten van den Aap. En als de vangarmen der poliep stuk gingen, at de Aap ze op, zoodat de poliep ten slotte stierf.

Toen kon de Aap weder naar land zwemmen en hij bracht de poliep mee en braadde haar (op kolen) voor zijn vleeschmaal. Wat de grootte van die poliep betreft, haar kop was als een groote kokosnoot en de Aap heeft haar (overmocht en) gedood, hoewel de Aap al bijna verdronk en indien hij niet de list gebruikt had van de poliep voortdurend te bijten, dan zou de Aap gestorven zijn. De Reiger echter had vleugels en kon vliegen. 


\section{II d. AANTEEK ENINGEN.}

Een kakalabẹ̆ is een waaier, waarmede het vuur in de keuken wordt aangewakkerd, gewoonlijk — en hier — van de bast van den echten sagoboom, maar ook wel van stijve bun ụ, d. w. z. het omhulsel van den kokosboom bij de kroon. komang is een kleine soort van landkrab, met scharen, die een zwart of grijs huisje met zich omvoert, evenals een slak. tawe lighạ malpku "dat gaat niet zoo spoedig van den haak af", wanneer de visschen bijten, het is dus voordeelig voor de vischvangst. - pakakasẹ̆, naar de uitspraak pĕkakas uit 't Mal. overgenomen, heeft in 't Sang. het equivalent kakoạ, in gevallen, waar men een bepaling er bij kan geven, bijv. kakoạ u sakaeng, u wal̨e, u tukang kalu, of waar een bepaling onirioodig is, bịv. in tawe makakoạ iạ, u tawe kakoạ-e "ik kan het niet maken, want ik heb er geen gereedschappen voor." paniring is van den stam siring (man.), hangt samen met sihing (man.) "gelijken op" en zegt zooveel als "(want) bedenk (dat)." - kinoạ bọu ḷẹ̆bo ěntana makẹ̆tị is een Hollandisme. Goed Sangireesch is: kn kawe lẹ̆bon ĕntana makẹ̆tị kinoạ (pinẹ̆koạ) kahĕmpeng e.

Dehọ (mĕ nd.) is "een sarong ombinden", eigenlijk "vastmaken". marehọ bijv. n. w. is "sterk", van een touw gezegd, zoo als maẹ̆dang "uithoudend" van een stof. Als w. w. beteekent marehọ ook "ergens achterblijven" (een voorwerp) door aan iets te blijven hangen. Nadehọ bet. dus eig. "(ten laatste) bleef het" "het bleef er bij, dat"; het heeft in 't taalgebruik de bet. van "ten laatste, eindelijk" en is dus een hulpwerkwoord geworden.

M ẹtongkạ (N. tongv. manongkạ) is "op de kolen bakken". — kinạ is "visch" en "vleeschspijze", tegenover kâng, waaronder gewoonlijk sago, pisang of batata verstaan wordt, die de hoofdspijzen der Sangireezen nitmaken. Rijst is eene lekkernij. Kuminạ is dus "visch, vleesch eten", kumâng wordt van 't eten der andere spijzen gezegd. 
IIte.

Tangú piạ i Waha nẹbaẹ sẹ́sane, sakaeng-e kahëmpeng. Eú́, kạẹbae e, kụ kinạ e napenẹe, taugú kai niwonohẹ, и paairing kai sakaeng kahĕmpeng! Tangủ niwonohẹ,, kṇ kinawonohang e kai su saghe. Tangú i Waha mèngkatewe kimalang kn dimarisị su himang, a mạhẹdọe sasi 'apakoho. Kutẹ kai nangaḷing su watn sémbau, tangú kai limandohẹ bọn himang $\mathrm{e}, \mathrm{k}$ ṇ makatahida kuhita, kere wango sëmbạ̣, kasarime. Nalindan bisịe sëmbẹka o, kntẹ kai nilawung u hamen kuhita, wisị-e sëmbẹka nakatahida e. Ingkûng n Waha e u: "Pèlọe iạ, kuhita! mëntëhang kai takụ tĕmpaleng, pakelang a sĕmbệka e èng!" Kai tala, kuhita e man tamaměllọ. $\mathrm{O}$ i Waha ĕndạ̣ mèhěngkasẹ̆, kai tawe mahèngkasẹ, n kuhita man tamamëllọ; i rĕdua man mëbẹ̆bawoḷeng.

I Waha ĕndaị mamol̨eng, i kuhita tanúe mamoḷeng soḷong baes-e su lohang u watu e. Tangú i Waha mĕngkate namakel' a laed-e sěmbệka, kutẹu kai sạ̣ nilawung n kuhita; èndai mĕlệěngkasẹ kai tawe mapëllọ. $O$ i Waha e mang èndạ̣ mạmoḷeng $\mathrm{n}$ wisị-e, kai mĕngkai makẹtị, tangú kate wisị u monane duanbẹka ipẹ̆pĕpapaed-e. Tangú i Waha saụ nệbera: "Pèlọe kuhita! mèntěhang i kau kai takụ kikiang." Kai kuhita e man tamamëllo u wisị-e ruambẹka nạun pinamakelẹ e.

Bọe' nẹ̆saụ namakel' u wisị u monane sĕmbẹ̆ka. Saụewe nihapus'u kuhita, tangú kate sĕmbệka wisị-e ipẹ̆pẹppapaed-e; sen tĕllunbệka nilawung, bisị i Waha, kntẹu katëlụe sulene namakelẹ, i rĕdua man mẹpẹ̌papaedẹ, o i Waha e timěngo e, mënsang kai akaḷeng kereapa, tadeạn i tataghuang ipèllọ a kuhita e; kai kuhita e mang kạpamolenge tanae sol̨ong liang $\mathrm{u}$ himang $\mathrm{e}$.

Tangú i rĕdua mèbệbawoḷeng doken den kạkohọe, kai hẹ̆do nate Waha e, n kai semben sạ̣ kạlanabe. Tangú i Waha semben tanakarea hĕngang-e waline, kụ mĕngkatewe sạ̣ namakel' a sĕmbẹka e, nte saụewe nilawung n kuhita e. Tangú sarang nilawung kệbi bisị-e, ute Waha e mëngkate mạngiki kuhita e r. mạngiki hamene nělawung si sie e; n sarang badang u Waha kai mëngkatewe nasne 
nilawung a kuhita e. Ené i rĕdua mĕdẹ̆darariha su rą̣ung u sasị, kai Waha e tawe nakauntung kuhita e. Kụ nadehọ nate, i Waha, apa keren kakontine! Arawe kinạ u Waha e nạun nasue nailang, sakaeng-e ute niwonohẹ̆ su sasị e.

\section{IIe. VERTALING.}

Er was eens een Aap, die in zijn eentje ging visschen. 'Zijne boot was een sago-pan. Terwijl hij aan 't visschen was en zij vol werd van de visschen, zonk zij, want bedenk, de boot was een sago-pan! Zij zonk, en wel op de riffen. Toen ging de Aap maar zwemmen, en ging staan op eene rots in zee, om de eb af te wachten. En toen is hij ineens van steen gaan verwisselen, is van de rots afgegleden en trapte op een poliep, zoo groot als een kokosnoot. Hij trapte haar met een zijner pooten, en die poot waarmee hij trapte, werd omstrengeld door de vangarmen der poliep. De Aap zeide: "Laat mij los, Poliep! straks zal ik u een trap geven, u schoppen met mijn anderen poot!" Maar neen, de Poliep liet hem niet los. De Aap trachtte zich los te rukken, maar hij kon niet los komen, want de Poliep wilde maar niet los laten; zoo trokken zij elkander over-en-weer. De Aap trok naar boven, de Poliep naar beneden, naar zijn hol in een gat van den steen. Toen trapte de Aap met zijn anderen poot, en die werd weder omvat door de Poliep; hij trachtte zich voortdurend los te rukken, maar kwam niet los. De Aap rukte maar met zijne pooten naar boven, doch zij bleven vastgehouden en nu hield hij zich nog maar met zijne beide voorpooten vast. Toen hernam de Aap: "Laat nu los, Poliep, straks zal ik u bijten!" Doch de Poliep wilde de beide pooten waarmede hij getrapt had, maar niet loslaten.

Daarop trapte hij weder met zijn eenen voorpoot. Wederom werd hij gebonden door de Poliep, en nu had hij nog maar één zijner pooten om zich vast te houden; drie pooten van den Aap waren reeds omvat. En toen, voor de derde maal getrapt hebbende, en terwijl zij elkaar zoo vasthielden, staarde de Aap in ééns nadenkend 
voor zich uit, (overleggende) hoe hịj de Poliep zon bedriegen, opdat deze hem zou loslaten, maar de Poliep bleef hem mar naar beneden trekken, naar het hol van de rots.

Zij beiden nu waren bezig elkander over en weer te trekken, van dat het nog ebbende was, maar de Aap stierf eerst toen het weder vloed werd. Toen vond de Aap geen andere uitkomst meer, en trapte weder met dien eenen poot, en toen werd die weder door de Poliep omvat. En toen al zijne pooten omvat waren, beet de Aap de Poliep, en beet hij hare vangarmen, die hem omstrikt hielden, voortdurend, want tot zelfs het lichaam van den Aap was geheel omwonden door (de vangarmen van) de Poliep. Toen worstelden zij beiden in zee, maar de Aap kon de Poliep niet overwinnen. En ten laatste stierf de Aap, die groote leugenaar! Maar de visschen van den Aap waren geheel verloren gegaan en zijne prauw was gezonken in zee.

\section{ILe. AANTEEKENINGEN.}

Bisi u monane is eigenl. onjuist; in zuiver Sang. moet bij de aanvoeging van een pron. suff. aan eene samenstelling welks leden door $\mathrm{u}$ of $\mathrm{n}$ zijn verbonden, het hoofdwoord tweemaal staan, de eerste maal met het pron. suff. Zie bl. 240. Bij eene prauw, waar men van een werkelijke monane en petone spreken kan, zou het juist zijn om bijv. te spreken van het dwarshout van monane; dan is monane niet met een ander zelfst. $n$. w. verbonden, maar is een bepaling van het voorgaande substantief. - M ĕdẹ̆darariha is eigenlijk "elkander afranselende" of "afstraffende." - A pa keren kakontine bet. woordelijk: "het ding, welks leugenachtigheid zoo groot is!" (apa, kerene, kakontine!). Apa is zeer verachtelijk, en wordt, jegens een mensch gebezigd, hoogst kwalijk genomen, niet minder dan binatang. Den zin der woorden geeft de vertaling boven weer. Men kon ook vertalen: "Zoo'n groote leugenaar!" 
IIf.

Bio piạ lai Waha nangakalẹe Ansuang. 'Tangú humotong e i Waha e kai sasaẹ nệbaẹ, kutẹu ringang u Waha ene kai i Wahoa e. Sarang nẹ̣baẹ, tangú sakaeng e kai kahěmpeng. Kutẹu i Waha kai narou. Ho piạbe lai baļung i rĕdua lewohẹ̆. Sarang kai narou, angkûng u Waha u: "Iạ bẹ̣dị kai narou, anu!" Angkûng u Wahoa u: "Ĕndaị lẹ̆sụ u pundaḷẹ̆". Kutẹu kai napẹ̆di pundaḷẹ. Saụ angkûng u Wahoa u: "Kĕnnangko lẹ̣sụ u palalaheng". Sạ̣ napẹ̆di. Angkûng u Waha u: "Endaị kai tamalẹ̆sụ e, ute kai koateng kereapa, anu?" Tangú i Wahoa nẹ̆bera u: "Mĕngkate ĕnsạ su sakaeng e". Ho, Waha nangènsạe wue, kutẹu kai nabẹ̆ka sakaeng i rĕdua. Sarang nabẹka, angknng u Wahoa u: "Enide anu! iạ tumĕllạ. Arawe, Waha e mĕngkate mẹ̆kẹ̆kalampang, kụkui si Wahoa makibẹ̆bẹ kadiongeng; kai Wahoa e tawe nahimang, mĕngkai timĕllạ d. nẹ̆bera u : "Nẹgahumpase, iạ mangambang; baḷinewe saļaku ene, kawe salanu, batụ kawe i kau nangĕnsạ u lewohẹ̆ su sakaeng i kadua".

Bọue' i Waha mĕngkate lai kimalang su sasi, nẹ̆timonạewe watu nirorokang u Wahoa. Tangú Wahoa e sĕngkakělla e mẹ̆sẹ̆sasisị su wowon batu e, tangú nahaungke i Waha, r. simengkangke su wowon batu ene, r. nẹ̆beráe i Waha si Wahoa u: "Mahi, ikadua mẹ̆kakutu, Wahoa". Angkûng i Wahoa u: "Iạ mẹ̆kutu si kau kal̨amona, anu!" Sarang i rĕdua mĕngkai mẹ̆dẹ̆darendehẹ̆, tangú Wahoa e tanakatahang dimendehẹ̆, kụ i sie nakutụe kaḷamona si Wahı. Kutẹu sarang i Waha nakapẹekutụe, tangú hẹ̆doewe nangẹ̆do n patikụ duk!̣ u panid'i Wahoa, r. rukụ u awạ-e nasuen dẹ̆dụe. Tangú i Wahoa e sen tanakatëllạ, kụ mĕngkate rụdarisị su wowon batu ene.

Bọue' Waha e mĕngkate sạ̣ kimalang, nangaḷing su watu waḷine, kutẹu sarang i sie mĕngkate rụdarisị su wowon batu ene, i sie kai mĕbẹ̆bera u: "Eịku, kai apa kapia, temang u ate". I sie ĕndị n mángawe tĕllu sụ̣e mĕbẹ̆bera kerene, kate piạ apa nẹ̆bera u: " Eị tĕngadẹ̆ èng! apạe mapia, temang u ate, arau?" Kaiso i sie rụdarisị ene kai su himang u saghẹ, bọue' kai lai sen kạkohọe, 
sasị e, hakịewen batu sen lụholong, kụ piạewen nirarisikang-e. Tangú i Waha nẹ̆kakawilọe r. nẹ̆bera u: "Ore, anu! iạ doken kanini mĕngkai maanu laín temang u ate kawe kalènggihe". Kutẹ i sie nakasilọe, piạ dụdarĕmmạ bawạ bena su aḷung u himang dẹ̆darisikang-e e. Sĕngkakělla e kai tangihiang. Kutẹu i rěduan Tangihiang ene mĕngkate mạhumbisara. Angkûng u Tangihiang e u: "Kai temang u ate suapa, Kạ Baha, 'kẹ̆kawohang-u?" Sinimbang i Kạ Baha: "Iạ mĕngkate mạbohang, u kai makạtahĕndung". Tangú Waha e nakiwal̨ọe kạpia si Tangihiang, angkûng: "I kau wue, Upung, kai rụduḷon temang u ate suapa?"Sinimbang i Tangihiang u: "Tala, Kạ Baha, iạ maḷain makạtahĕndung kere i kau". Kaiso i rĕdua mạhumbisara kerene, kai sasị e semben kạkohọe, hakị namara ĕnne rĕdarĕmmaheng u Tangihiang e. Tangú Tangihiang e narą̧eng kinaaką̧eng i Waha, èndạ̣ bọu mahumbisara e.

Sarang kinamarâng Tangihiang e, tangú i Waha měngkate mệtẹ̀timbang, mĕnsang ute Tangihiang ene koatengken sie kerea', kate sĕngkianu piạ saghiasa ĕnsaẹ; kutẹu kai Ansuang. I Waha, sarang nakasilo Ansuang e, tangú nẹ̆bera u: "Upung, Upung! kai wọu apa?" Angkûng u Ausuang e u: "Aị tataļaṇ̣, ạ̣ tatalewa, mĕntèhang $i$ kau ren buhụ́e ipěndaha isi, ipanẹ̆bu pangilạ". Angknnng u Waha e u: "E! ẹ! Upung! abe kerene, sasaẹko i kadua mangua komboḷeng dadẹ e, Upung; den ipendaha isi, ipanẹ̆bu pangilạ i kadua". Ansuang e nakiwal̨o, mĕnsang Tạngihiang suapa. Angkunng i Waha u: "E radẹ se" ". Bọue' i rĕdua ene mĕngkate sasaẹ nangua tangihiang ene.

Nasuen uane, kutẹu kai tạ kîng i rĕdua, tangú i Kạ Baha nẹ̆bera si Ansuang e u: "I kau pahẹ̆doko sini, Upung! iạ den sumagha kâng i kadua". Tangú marĕngụ u apa, weran bio, ènsaẹ e nawaḷi, i Kạ Baha, ringangu wusạ duan kalu, wusạ boḷan-kĕhu. Bọue' nịtatûng. Sarang nasasạ, kutẹu kai lai tạ akẹ inumang i rĕdua, ené i Waha e nẹ̆berạe si Ansuang: "Iạko mĕlagha kinạ i kadua e, Upung! i kau panuhụko akẹ: mĕntěhang kumâng boue' tạ inumang-e!" Angkûng u Ansuang u: "Endaị kai tạ bowong-e Kạ Baha!” Tangú i Waha nẹ̆deạe wue wowong, kutẹu i sie nĕlẹ̆s!̣ bowong e kai niapatẹ̆pasẹ̆ su kihị-e, wọe' nighĕllị si Ansuang. Tangú Ansuang e taraị nanuhụ akẹ.

Su likuden Ansuang nanuhụ akẹ e, kinạ nilëllụ d. nitongkụ e nasuée nasasạ, tangihiangkewe sĕmbua ene. Bọne' i Waha e mèngkate nawị $\mathrm{u}$ kinạ e su kotọ u kalu sĕngkalu, patehangkewe Ansuang e tamakareạ. Kaiso i sie mĕgẹ̆ganaseng mạmunin kinạ e, kaiso 
Ansuang e man bẹ̆dan tạdise wọu nanuhụ akẹ. Sarang nasuen bunine kinạ d. kâng ene kěbị, tangú i Kạ Baha e tarạ̣e nẹ̆tuhụ si Ansuang. Sĕngkarumating-e nẹ̆berạe su Ansuang e, i Kạ Baha : "Kâng d. kinạ dadẹ sen hakị nasue nasasạ, o kawe taligha sumongo". Angkúng u Ansuang e u: "Akụ tawe lighạ mapenẹ doken kanini!" Tangú i Waha e nẹgĕllịen bowong-e si Ansuang e, pinakipanuhụke akẹ. I sie éndạ nẹ̣tuhụ e, kaiso kẹ̆bị kinạ e sen nasuen bunine, r. i sie nẹ̆bawawe bowong-e, u ene mang mạngakaḷẹ su Ansuang e. Tangú wuhụ́e napenẹ, bowong niwawan Baha e, arawe wowong niwawan Ansuang e sen nịbawala, u tawe ligha napene. Saráeng nasasaẹe soḷong apang e, Ansuang e, tangú i Waha e sen timalạng, arawe Ansuang e sarang nakasilo kinạ d kâng kai sen nasue tạdịe, tangú wowong akẹ mạpapasâng su wĕmbang-e mĕngkatewe nihipe, wọue' i sie nẹ̆tuhụ si Waha. Ansuang ene makatangga manga kalu ghaguwạ e, hakị mạpapẹ̆di.

Arawe Waha e, sarang dụdaḷeng dụdạleng, kutẹu kai nakaĕbạ mamaměhasẹ̆ lana, tangú i sie naghĕlle naměhasẹ̆, arawe taghuang e uté niapasohọ soḷong baḷene. I sie nẹ̆bera u: "Rakọko soḷong bale malighạ, iako mamĕhasẹ lana e." Ho, nakoạbe kerene. Bone’i sie mĕngkate rimarisị su l̦ papĕhaseng e, o kate piạ tau ěndaị mĕgongge, lupa, r nẹ̆bera tau ene si Kạ Baha, angkûng: "I kau e ĕng, Baha! nangakaḷẹ̆ siạ; kinạ d. kâng nasue niwuuninu e, ěng?" Angkûng u Waha u : "Eịku, Upung! iạ tala wue. Doken mąlukadẹ̆ iạ měngkai sini. Harusẹ̆be piạ tau tụtaḷang taraị kere', lupa, takụ pakịbaḷong kai semben tanakasimbang, ute mahunẹ kai nạun nangakalẹ si kau e, ěng, Upung? Dakọko tarạ̣ tuhuke; wuhu-wuhu sasahe." Angkûng u Ansuang e u: "O i kauwe, kai mẹ̆kẹ̆koạ'a?"

"Kai mĕlẹ̆hapa wansị i Wawụku."

Tangú Ansuang e kai nangaho, u i sieko mẹ̆bansị, kaí i Waha e tawe mẹ̆gĕllị. Sarang tanakarendehẹ̆ si Ansuang, tangú i sie namaláe r. nệbera u: "I kan, Upung! darisị su taḷoarane, kụ́ iạ mangangobị-e. Sarang nararisị, tangú mĕngkate nilupitẹ̆ Ansuang e. Man kạpẹ̆kiạratage u: "abe raḷihạ!" kai i Waha e semben tawe nạhimang, mĕngkate nihakidẹ, papěhaseng e; wọne’i sie timaḷang kạpia kụ nakahombang liakung u tẹ̆mpu. Arawe, teng Ansuang uté man mẹ̆kẹ̆kaḷmpiring, kụ mạpotọ kal̨uwaeng-e. Tangú papĕhaseng ene naraleng naghoghahẹ̆ pinẹ̆kal̦umbiageng u Ansuang. Bọue' Waha e nẹ̆tĕngkataho su ḷakung u tĕmpu ene. Sengkianụ́ewe piạ tau ĕndaị mẹ̆gongge, kutẹu katewe i Ansuang, d. kạberane 
u: "I kau e, ěng, Baha, mahunẹu i kau man mapạkasilakạ u iạ e, eng!" Angkûng u Waha u: "Be! i kau, Upung, tilang bue arau kawe pulu; iạ taumatawe tarimẹ̆daḷeng suapa, rokeng kanini, wọue' i kau mĕhodatẹ̆ kerene siạ. Kẹ̆tạben iạ nakasilo tau tụtaļang tarạ kere'; takụ pakịbaļông, kai tawe nakasimbang, u kai lupa." Angkûng u Ansuang e u: "I kau kawe mẹ̆kẹ̆kapú?" Sinimbang u Waha u: "Iạ kai mĕlẹ̆hapa papehẹ i Wawụku." Kutẹu Ansuang kai naghĕlle mẹ̆papehẹ dingang, kaí i Waha tawe mangonggọ. Sarang i sie tanakarendehẹ si Ansuang, tangú i sie měngkate nangonggọ. Sarang i Waha nangaḷing bọue', i Ansuang nạiang su lịkong u tĕmpu e, tangú tĕmpu ene mĕngkate nělawung kaḷwaeng u Ansuang. Tĕmpu ene, kasariane kere kal̦un tiladẹ kawuhuang. Bọue' i Waha saụwe timaḷang tarạ̣, kụ nakasilo mĕndararang. Bọue' i sie nĕndarangke wue, arawe apan mẹ̆dĕndarang kal̦amona e uté niapakapuḷẹen Baha e. Sĕngkakëlla piạewe tau ĕndạ̣ mẹgongge, kutẹu kai semben i Ansuang d. kạberane u: "Enide! i kau e, ĕng, Baha! i kau kai apạe kapiane, ĕng, pane! mĕngkate kẹtạ mạngakaḷ̆ siạ." Angkûng i Waha u: "Be! Upung, kai wọu nakiwingihẹ̆ su anun sai; kawe wukang, ĕndaị kai mạngẹ̆nsil' u papate. Iạ e samatang nakasilo tau nasahe, kụ l̦upa tarạ̣ sen saḷa tamakal̦aļempang." Angkûng i Ansuang u : "I kau kai měkẹ̆kapura sene?" Angkûng i Waha u: "Kai mẹ̆dĕndarang."

"Kụ kawe apa nakahamụ pĕnnad-u?" Sinimbang u Waha u: "Kai nẹ̆tongkạ u uase, niapakahamụ, bọue' nirẹ̆kạ su pĕnnadẹ̆ku."

Tangú Ansuang nẹ̆berạe u: "Siạ koạko lai kerene". Tangú i Waha e nẹ̆berạe u: "I kau makakẹ̆dang bue', pĕndệkateng e?" Nẹ̆bera Ansuang e u: "Makakẹ̆dang bue". Tangú i Waha e měngkate nẹ̆tongkạ u uase arẹ̆gan 'sẹ̆sal̦eng darua. Sarang nahımụ, tangú i Waha nẹ̆berạe, angkûng: "Mapia, i kau kai 'hapusang, tadeạu tawe kumanoạ". Tangú Ansuang ene nihapusẹ̣ su limane r. su wisị-e r. niapakatanạ marĕmmasẹ̆, dụdaḷoka. Sarang nahamụ-hamụ kẹ̆bị uase ene, mĕngkatewe nitatẹ̆kạ su sĕndihang u Ansuang e; wọue' i sie timal̦ang saụ. Kutẹu Ansuang e nẹ̆bansage, r. nẹ̆berạe: "Enide Waha! i kau kai nangakalẹ̆, hunẹ, ĕng!" Ené i sie nẹ̆kalumpiringke, tangú uḷang lahapusẹ̆ si sie e nạbẹ̆sụe, wọue' i sie tarạ̣ nẹ̆tuhụ si Waha. Arawe uase nạun nitẹ̆kạ e uté man sural̨ung u wadang u Ansuang e. Kaiso tarạ mẹ̆tẹ̆tuhụ si Waha e sen kạkindoree, u mamben 'patêng i Waha ene.

Kutẹ i Waha e kai nạun sen nakaěbạ pahighi, loang-e manga pitun dẹ̆pa. Kutẹu i sie mang kụkaiang su wiwih'u pahighi e, o 
sĕngkianụewe ĕndaị, Ansuang e, kụ mĕngkatewe narasai sen kĕlânge, r. kạberane u: "Enide! Baha ĕng? matẹe iạ bẹ̆dị. Tawẹ daḷeng-e waļine: i kau man sen mạmate siạ, ene. Kaļamona i kau e nangakaḷẹ siạ, bọue' samurine i kau mạmatẹe siạ. Hẹ̆doko, i kau! abe taḷang! iạ ini demben mangaho waḷisẹ̆ku. I kau man takụ patêng kahĕngang". Baha e, sarang kai nakaringihẹ̆ beran Ansuang e, kai sen ene kasẹ̆gad-e, man kai sạ̣a liminingodẹ̆ d. nẹ̆bera u: "Kate, kai, Upung! i kau kai mẹ̆bẹ̆bera siạ kerene unu? Saḷaku kai a', Upung? Arau i Upung kai ěndạ̣ dimagang sarang ini, watụ kai mạmate siạ e? a, roken maļukadẹ iạ mĕngkai sini, tawe rimẹ̆daleng suapa". Baha e uté kai mẹ̆nẹ̆nalang u konti. Boue' Waha e nẹ̆berạe sạ̣ angkûng: "Kanini piạ tau taraị kere', lupa, kụ sen tanakasimbang pakịbaḷ̂ng". Tangú Ansuang e nakiwaļo, měnsang i sie kai mẹ̆kẹ̆kapura sene. Angkûng u Waha e: "Kai mẹ̣ẹhapa pahighin Bawụku". Angkûng u Ansuang e: "Kai mapulu mĕndenọ su pahigi ene." Kai Waha e man tamamala, n madirin i sie nade 'pẹ̆berâng i Wawụ-e. Sarang i Waha tanakarendehẹ su Ansuang e, tangú i Waha mĕngkate namala pinakipĕndenoi su Ansung s. Sarueng Ansung e tanae timumpa, kuteu uase su wadumg-ts simahokas. Sarang simahoka, tangú i Ansuang naraleng mate, sumu u kontin Baha ene, r. 'pangangakal' i tataghuang su Waha ene.

Nahẹpusè:.

\section{IIf. VERTALING.}

Een verhaal nog van den Aap, die een Reus bedroog. - Eerst ging de Aap uit visschen, en de metgezel van dien Aap was de Reiger. Toen zij gingen visschen, was de boot een sago-pan. Daar werd de Aap dorstig. Doch zij hadden ook een jonge klapa-noot tot teerkost meê. Toen hij nu dorst had, zeide de Aap: "Ik gevoel mij dorstig, vriend!" De Reiger zeide: "Maak er dan een gat in met de roeispaan." Maar zie, de roeispaan brak. De Reiger hernam: "Probeer hem eens door te krijgen met den mast." Deze brak ook weer. Toen zeide de Aap: "Nu zij niet door wil, wat moet er nu 
an gedaan worden, vriend?" Toen zeide de Reiger: "Werp haar dan neer op de schnit!" De Aap wierp haar toen neer, en daar brak hun vaartuig. Toen het brak, zeide de Reiger: "Au, vriend! ik ga vliegen!" De Aap echter sloeg mar met armen en beenen, den Reiger roepende om hem ten minste te willen ophouden; maar de Reiger luisterde er niet naar, en vloog maar heen, zeggende: "Ik bedank er voor om te helpen; 't is niet mijne schuld, maar de uwe, omdat gị het zijt, die de klapa op onze prauw hebt geworpen."

Toen ging de Aap ook maar zwemmen in de zee, koers houdende naar een steen, waarop de Reiger was gaan zitten. Hij zag den Reiger zich pluimstrijken op den steen; toen naderde de Aap en klom op dien steen en toen zeide de Aap tot den Reiger: "Kom, laat ons elkâtr luizen, Reiger!" De Reiger zeide: "Ik zal u eerst luizen." "Kom!" zeide de Aap "laat ik u 't eerst luizen, vriend!" Toen zij beiden maar met elkaûr aan het redetwisten waren, kon de Reiger het in 't redeneeren niet volhouden en werd hij cerst door den Aap geluisd. En toen de Aap dan in de gelegenheid was, hem te luizen, hield hij eerst op toen alle veeren uit de vlerken van den Reiger en de veeren van zijn lichaam uitgetrokken waren. Toen kon de Reiger niet meer vliegen, en stond daar maar op dien steen.

Daarna zwom de Aap weder naar een anderen steen, en terwijl hij daar maar zoo op dien steen stond, zeide hij: "Ach, hoe lekker is toch de smaak van lever!" Ongeveer drie maal had hij aldus gesproken, toen er opeens iets zeide: "Hè ja! 't is iets lekkers, de smaak van lever, nietwaar?" Hij nu stond daar op de klip van het rif, en de zee was reeds aan 't ebben, zoodat de steen reeds boven water uitstak, en hij iets had om er op te staan. En de Aap keek ijverig rond en zeide: "Ja, vriend, ik sprak den heelen tijd ook al daarover, dat de smaak van lever toch zoo lekker was." En toen zag hij dat daar iets plat lag op den bodem der zee onder den steen waarop hij stond. Hij zag dat het een mensehenhaai was. En hị en de Haai vingen een gesprek aan. De Haai zeide: "De smaak van welke lever is het, vriend Aap, waarover gij riept?" De Aap antwoordde: "Ik riep het maar, omdat ik 't mij herinnerde." Daarop vroeg de Aap weder aan den Haai: "En gij, Voorvader, naar den smaak van welke lever watertandt gij?" De Haai antwoordde: "Ach, ik herinner 't mij ook maar alleen, evenals gij, vriend Aap!" Maar terwijl zij aldus aan 't spreken waren, 
was het reeds eb geworden, zoodat het zand waarop de Haai lag, droog was geworden. En de Haai was ten laatste bedrogen door den Aap, nadat zij zoo met elkander gesproken hadden

Toen de Haai door de droogte was verrast, overwoog de Aap langen tijd, wat hij met den Haai zou doen, toen er plotseling een gedruisch aankwam, en zie, het was een Reus. Toen de Aap den Reus zag, zeide hij: "Voorvader, Voorvader, vanwaar komt gij?" De Reus zeide: "Bazel niet zoo, verkoop geen gekkepraat; straks zal ik mijne tanden pas in uw bloed doopen, en er mijn gebit in blusschen". De Aap zeide: "Nu, nu, Voorvader, niet zóó; laat ons naar het strand gaan, dien haai daar snijden, Voorvader, wij zullen onze tanden eens in 't bloed er van doopen; ons gebit er eens in blusschen". De Reus vroeg, welke Haai of het was. De Aap zeide: "Een Haai daar voor aan 't strand." Daarop gingen zij naar het strand, dien Haai snijden.

Toen het snijden was afgeloopen, hadden zij geen spijzen, en vriend Aap zeide tot den Reus: "Wacht gij hier, Voorvader! ik ga naar den tuin, eten voor ons halen." En, wat zou het wel lang duren in 't verhaal van een sprookje - daar keerde vriend Aap terug, met twee pisangboomen, en met de soort boḷan-kĕhu. Daarop werden zij gekookt. Toen zij gaar waren, hadden zij ook al geen drinkwater, en toen zeide de Aap tot den Reus: "Laat mij nu onze visch stoven, Voorvader; ga gij eens water scheppen, wij gaan straks eten, en er is geen drinken!" De Reus zeide: "Er is geen water-bamboe, vriend Aap!" Toen ging de Aap maar weer op de zoek uit naar een water-bamboe, en wat deed hij - toen hij dien doorboorde, stak hij ook den bodem door en gaf hem daarna den Reus. Daarop ging de Reus water scheppen.

Terwijl de Reus weg was om water te scheppen, werd de visch in de bamboe-kokers en op het kolen-vuur gaar, die geheele haai, weet ge? Daarop klom de Aap met de visch in den top van een boom, waar hij dacht dat de Reus hem niet zou kunnen vinden. Doch terwijl hij aldus gedruisch makte bij het verbergen van de visch, was de Reus nog steeds niet terug van het water halen. Toen al de visch en de spijs was verborgen, ging de Aap heen, den Reus achter na. Met dat hij bij hem aankwam, zeide de Aap tot den Reus: "Al de spijs en de visch is er al gaar door geworden, (door het verloopen van dien langen tijd) en nog komt gij niet spoedig terug!" De Reus zeide: "Hij wil ook niet spoedig vol

、 worden, van straks al!" Toen gaf de Aap zijn bamboe-koker aan 
den Reus, om hem daarin water te laten scheppen. Doch hem zoo achterna komende, had hị al de visch reeds verborgen, en hij bracht een bamboe-koker mee, want hij was steeds den Reus bedriegende. En toen eerst werd de bamboe-koker, die door den Aap was meegebracht, vol, maar de bamboe die door den Reus was meegebracht, was reeds opgegeven, omdat hij niet spoedig vol werd. Toen de Reus naar het strand ging, vluchtte de Aap reeds. De Reus echter, toen hij zag dat al de visch en de spijs er niet meer was, wierp den bamboe-koker, dien hij over den schouder droeg, weg, en ging daarop den Aap na. Als die Reus tegen de groote boomen stiet, dan braken zij in stukken.

De Aap echter trof, toen hij steeds zoo voortging, olie-persers aan, en hij vroeg om te persen en liet den eigenaar naar huis gaan. "Ga voor een korten tijd naar huis! ik zal de olie eens persen", zeide hij. En zoo geschiedde het. Daarna ging hij op den hefboom staan, en terwijl de pers maar zoo kraakte, kwam daar iemand aanwaggelen, hijgende, en die zeide tot Vriend Aap: "Gij, niet waar Aap, zijt het die mij bedrogen hebt; al de visch en de spijze hebt gij verborgen, niet waar?" De Aap zeide: "Neen toch, Voorvader, ik heb het niet gedaan. Van den vroegen morgen af was ik steeds hier. Natuurlijk was het dus, dat er iemand zoo heen (dáár naar boven) vluchtte, buiten adem; ik ondervroeg hem, maar hij kon al niet meer antwoord geven. Zoo! hij had u dus bedrogen, Voorvader? Ga hem achterna! hij is pas voorbijgegaan". De Reus zeide: "Lin gij, wat doet gij?"

"Ik bewaak de fluit mijner Meesteres."

Toen wilde de Reus het hem uit de hand rukken, want hij zou eerst fluiten; doch de Aap wilde het niet toestaan. Toen hij tegen den Reus niet op kon, stond hij het dan toe en zeide: "Gij, Voorvader, ga in het midden staan, en ik zal de bespeler zijn". Toen hij er in stond, ging hij hem knellen. Wel jammerde de Reus, dat hij niet te hard moest doen, maar de Aap luisterde er niet naar; hij bond de pers vast, en ging weder op den loop en trof een gekronkelde slang aan. De Reus echter wrong zich in bochten en zijn middel brak al haast door. Ten laatste was die pers vernield door het wringen van den Reus. De Aap zette zich vervolgens neder in de kronkeling der slang. Daar kwam plotseling weer iemand aanwaggelen, en zie, het was weer de Reus en die zeide: "Gij Aap, gij tracht mij dus steeds in 't ongeluk te storten, niet waar?" De Aap zeide: "Wel Voorvader, 5e Volgr. VIII. 
zijt gij nu bij uw verstand of zij gij gek? ik ben iemand die nergens heengegaan is, sedert straks, en nu zoudt gij mij zoo belasteren. I $\mathrm{k}$ heb alleen iemand dátárheen naar boven zien vluchten; ik ondervroeg hem, maar hij kon niet antwoorden, want hij was buiten adem." De Reus zeide: "Wat zijt gij dan bezig te doen?" De Aap antwoordde: "Ik bewak den gordel mijner Meesteres." Toen is de Reus hem gaan vragen om zich ook eens er mee te mogen omgorden; doch de Aap stond het niet toe. Toen hij 't niet tegen den Reus kon volhouden, liet hij het maar toe. Nadat de Aap van zijue plaats was gegaan, ging de Reus in de kronkeling der slang zitten, en toen omving die slang het middel van den Reus. Die slang nu had de grootte van een pinang-stam, die nog jong is. Daarop vluchtte de Aap weder verder weg naar boven, en zag lieden, die zich bij een vuur warmden. Daarna ging hij zich warmen, maar zij die zich daar te voren warmden, zond de Aap naar huis. Daar zag hij, dat er weer iemand kwam aanwaggelen, en het was alweer de Reus en die zeide: "Au, gij Aap! wat een beste zijt gij toch, niet waar kameraad! gij doet niets dan mij voortdurend bedriegen!" De Aap zeide: "Wel Voorvader, bij wien hebt gij u laten inschenken? ge moet wel dronken zijn, dat ge mij beticht van doodslag. Ik heb alleen maar iemand zien voorbijgaan, en hij was buiten adem; hij kon bijna niet meer voortstappen, daar naar boven gaande." De Reus zeide: "Wat doet gij daar?" De Aap zeide: "Ik warm mij."

"En wat heeft uwe billen rood gemaakt?"

"Ik heb ijzer in 't vuur gelegd en gloeiend laten worden en heb het daarna tegen mijne billen aangeplakt," antwoordde de Aap.

Toen zeide de Reus: "Maak de mijne ook zoo!" De Aap zeide: "Kunt ge 't wel uithouden, als het op u geplakt wordt? "Ik kan 't wel uithouden", zeide de Reus. Toen gloeide de Aap een stuk ijzer, waaruit men twee houwers kon smeden. Toen het rood was zeide de Aap: "'t Zou goed zijn dat gij werdt vastgebonden, opdat gij geen beweging maakt". Daarop werd de Reus aan handen en beenen gebonden en moest rustig op den grond blijven liggen. Toen dat ijzer geheel en al rood gloeiend geworden was, stak hï het in de zijde van den Reus; daarna ging hij weder op de vlucht. Toen schreeuwde de Reus en zeide: "Au, Aap! gij hebt mij dus bedrogen niet waar?" Toen wrong hij zich heen en weer, en het gumutu-touw, waarmee hij gebonden was, brak, en daarop ging hij den Aap achterna. Maar het ijzer dat ingestoken was, zat nog 
in het lichaam van den Reus. Doch den Aap achterna zittende, dreigde hij al, dat hij dien Aap zeker dooden zou.

De Aap nu had al een put aangetroffen, met eene wijdte van ongeveer 7 vadem. En toen, terwijl hij daar voortdurend zat op den rand van den put, kwam daar plotseling de Reus weer aan en 't was hem aan te zien, dat hij veel pijn leed, en hij zeide: "Au Aap, he? ik gevoel me alsof ik ging sterven. Het is bepaald niet anders: gij woudt mij den dood aandoen! Eerst hebt gij mij bedrogen, en daarna zocht gij mij te dooden. Wacht gij eens! vlucht niet! ik zal nu mijne wraak eens nemen. Ik zal u zeker dooden." De Aap nu, toen hij hoorde, dat de woorden van den Reus bepaald reeds zoo stellig waren, keek eenigszins verbluft en zeide: "Hoe nu, Voorvader, waarom spreekt ge zóó tot mij? Wat heb ik misdaan, Voorvader? Of is Voorvader tot hier gekomen omdat hij mij wilde dooden? En toch zit ik van den morgen af reeds hier en ben nergens heengegaan." Maar de dap speelde met leugens. Daarop hernam de Aap: "Straks is iemand zóó heengegaan, hijgende, en hij kon al niet meer antwoorden, toen hij ondervraagd werd." Toen vroeg de Reus, wat hij daar deed. De Aap zeide: "Ik bewaak den put mijner Meesteres." Toen wilde de Reus een bad nemen in dien put, doch de Aap wilde het volstrekt niet toestaan, om niet, zooals hij zeide, knorren van zijne Gebiedster te krijgen. Toen de Aap niet tegen den Reus kon opspreken, stond hij den Reus toe er in te gaan baden. Zoodra de Reus er in gesprongen was, siste het ijzer dat hij in zijn lichaam had steken. Toen het ging sissen, stierf de Reus ten laatste nog, tengevolge van de leugens vau dien Aap, en zijn eigen bedriegerijen jegens dien Aap.

Eind e.

IIf. AAN'TEEKENINGEN.

A n u is een woord, waarbij menschen die gemeenzaam met elkander omgaan, zonder een inniger vriendschap te sluiten, elkaar roepen; 't is zooveel als "kameraad." Door iemand met wien men gelijk 
staat voor een derden zijn an u te noemen, bewijst men hem een beleefdheid, en eene zekere mate van vriendschap. Men zal het echter niet licht van de aanzienlijksten hooren; die geven elkaar den hun toekomenden titel. An u kan ook tot een sasĕnggahị gemaakt worden, maar is dan niet eigenaardig. - Voor m ẹ̆ka la mpang zegt men ook mẹ̆kalampuang. Het is het geijkte woord voor een kind, dat met armen en beenen zwaaiende, naar zijne moeder toe wil (mẹ̆lalo si ninang-e). - nẹ̆gahumpusẹ alleen of met volgend Fut. bet. "Ik bedank er voor om te...." De afleiding en de bet. van den stam zijn onbekend.

Mẹtimona, van den stam mona "voorsteven", is blijkbaar met een voorvoegsel ti gevormd, welks genasaleerde vorm bl. 135 besproken is. - makatahang is van 't Mal. tahan gevormd, dat in den vorm mẹ̆tatahang "lijden, ondergaan" en "uithouden" het burgerrecht heeft verkregen in 't Sang., hoewel dit met kẹ̆dang dezelfde gedaohte kan uitdrukken.

Mángawe "ongeveer" is samengesteld uit manga (in den onbepaalden zin; zie bl. 218) en wue. Het nadrukteeken op de

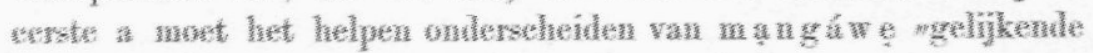

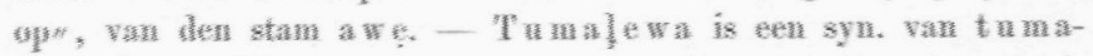
lann (waarschỉnlik van tanu, gernakt tot talanu) mar is groffer, en een jongenswoorl. Over den vetatieven vorm marin deze woorden hier voorkomen zie bl. 182.

$\mathrm{K}$ emboleng of komboleng is eig. een ander dier dan de tangihiang of mmensehenhari", het is n.l. de haa die gegeten worlt, en dien de Sangireezen, als zij hem gevangen hebben, achter hume pranw aan voorttrekken (mamoleng), daar hume pranw soms kleiner is dan het dier of de dieren die ze gevangen hebben, naar welke- wijze van naar wal meenemen de viseh waarsehijnlijk genoemd is.

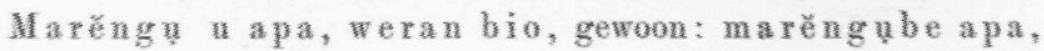
weran bio: "wat zouden ze wel lang duren, de woorden van een sprookje," m. a. w. "in een sprookje heeft men het maar voor het zeggen". - Welke pisang bolan kĕhn (grijze van het boseh) heet, kan ik niet zeggen; bolan sas i is ook eene boomsoort.

Sn likud' $u$ of su likuden machter den rag van", is een gewone nitdrukking voor "tijdens de afwezigheid van" - nilëllu bet. "in een lëllu (bamboekoker van sleehts één lid) gedaan." Zulk een bamboe, met vleesch, rijst, of een hutspot van spijzen gevuld, wordt schuin staande over 't vuur gehouden, totdat 
men haar er af pellen kan; dan blijft er een soort van worst over.

Mangobị is "tokkelen, met de vingers bespelen" en kan dus van eene fluit niet goed gezegd worden. - kalun tiladẹ kawuhuang. De stam van den pinang is in zijne jeugd het dikst. De vertaling van kawuhuang is op goed geluk; het komt van den stam buhu.

Arẹ̆gan 'sẹ̆saḷeng darua "waaruit er twee kunnen gesmeed worden", nl. peda's, houwers of hakmessen, het meest gewone smidswerk, dat op Sangir gemaakt wordt. - Beter dan dẹ̆kạ (měnd.) "plakken, kleven" zou hier tëmpelẹ̆ "tegen aan drukken" zijn. - ling odẹ "verbluft rondkijken", is waarsch. een bijvorm van ligo "met opgespalkte oogen rondkijken." 
III.

BAWIO, PIA I WAHA, I MATJAN, I MEO D. I KAMBING.

Tẹ̆tạ-e: piạ i Waha, kụ piạ ěllang-e i Matjan, i Meọ d. i. Kambing. Tangú piạ bal̦en sire su rẹ̆duh' u apeng. I Waha e tangú kai piạ dalombone. I sire tahĕllang kai sasíe nẹ̣paparingang nĕlombo. Tangú ḷĕmben bọu kininaseng i sire kai tinapa. Sĕngkariọĕlone nẹ̆saụ nĕlombo, r. nahumbisarạe, mĕnsang i sai mĕhapa wale e. Angkûng u Meọ e u: "Iạko mĕhapa wą̣e." Kaí, su hondạ u wậe kai piạ batang masaria. Kûng u Waha e u: "I kau Meọ! kĕnnangko pĕhipen batang e su panindụ." Tangú i Meọ e mĕngkate nangaliụ batang kṇ mểngkate jẹ̆sĕmpare. Tangú Waha e nẹ̆beráe si Meọ e u: "I kau pěhapạe waḷe e, Meọ!" Tangú i sire waline sasáẹe nĕmpĕlombo.

Su likuden sire nĕlombo e, tangú kate sĕngkianu piạ apa ghụgalẹgehẹ̆, ĕnsaẹ bọu kĕhu; matangga su kalu, mapapẹ̆di, mitangga su watu, maralọ́e. Kutẹu kai Ansuang. Sĕngkarĕnta mĕngkate nẹ̆gĕllị u tabeạ si Meọ; bọue' Ansuang e mĕngkate himaung paha e, kụ kiminạ. Ute ho, Meo e mĕhipe tamakahipe, mĕngkatewe * nangahụ Ansuang e; kụ 'kahukangkewe rasị bọu palang-e hẹ̆do iẹ̆do u wawạ bisị; gẹ̆si mĕngkate pẹ̆sĕnsaing. Kûng u Ansuang e u: "Mĕngkai kahụ, Meo! i kadua hẹ̆do mělal̦ia u iạ masuen kinạe." Sarang i sie nangẹ̆do kiminạ e, Ansuang e mĕngkatewe namele su Meọ; Meọ e sasaẹ nawintuing soḷong laudẹ̆. Tangú Meọ e mĕngkatewe ĕndạ̣ kimalang soḷong duḷunge; kụ nipelen Ansuang doken malukadẹ̆, Meọ e hẹ̆do narĕnta u semben bawĕllo. Sarang narĕnta su rulunge, mĕngkatewe tarạ̣ kạpia soḷong baḷe.

Meọ e napĕllọ su wạ̦e, ute mĕlạ̣ombo e narĕnta. "Piạ apa, Tuang, pahan kitẹ tahamawu kanini kai nisongông u Ansuang, tangú iạ kai nịpapele soḷong laudẹ̆, kụ iạ ĕndaung kai lai wuhu sasongo, ěndạ̣ saụ kimalang bọu l̦audẹ̆." Tangú angkûng u Kambing e: "Iạko riọello mĕhapa wą̣e." Tangú sạ̣e su sĕngkariọĕlone, angkûng u Waha, nẹ̆bera si Kambing e: "I kau kĕnnangko panapuạ batang bawa e." Tangú Kambing e mĕngkatewe nanunge watang ene, kụ 
sinalone tamai-ramahi. Bọue' i sire wą̣ine nanĕntangken Kambing e, niapĕhapa wal̨e, wọue' i sire sasaẹ saụ nĕlombo.

Suļikudewen sire nęl̨ombo e, sĕngkakělla Ausuang e semben sạ̣ simongo, sĕngkatotọ man su pahan kinạ e, kụ kiminạ. Tangú i Kambing e mĕngkate nanunge Ansuang e kụ kẹ̆tạewen gẹ̆sin Ansuang pẹ̆sĕmbaing. Angkûnge u Ansuange u: "Mĕngkai sunge Kambing! iạ hẹ̆do mamalisẹ̆ u wọu kuminạ." Nasuen kinạe, Ansuang e mĕngkatewe namele Kambing e, kụ nawintuing kạpia soḷong l̨audẹ̆. Tangú sĕngkakĕlla i Kambing ěndaị e wue tụtapu wọu laudẹ̆, nạun, kụ hẹ̆dọewe nasongo u nẹ̆sion sire nĕmpělombo e. Tangú i Kambing e nẹ̆berạe wue si sire nĕmpělombo e, u: "Piạbelai apa, Tuang! kinạ su paha e : i Ansuang sạ̣ dimĕnta kanini, kụ sĕngkahumpa sen su paha." Angkûng u Masang u: "Hẹ̆doko wue! riọello iạko mĕhapa wạ̦e e."

Ho, sěngkariọelone, tangú i Matjang nĕhapa wal̨e e, kụ sul̨ikud u němpělombo e, sěngkakĕlla Ansuang e semben sạ̣ dimënta. Sĕngkahumpạ mal̦ain su paha. Tangú i Matjang mĕngkate nanapuạ Ansuang e kụ ilẹ̣hipe; sarạeng sen mạsapuạ, angkûng u Ansuang e u: "Hẹ̆doko, iạ den mamamẹ̆da." Bọuene, mĕngkate lai nihipe, i Matjang, nakoạ ļai kere i Meọ d. i. Kambing.

Tangú angkung i Waha u: "I kamene sasaẹ pĕlombo; iạ e mĕhapa wal̨e e." Tangú i Waha e mĕngkate nangambung u kalu l̨awo l̨awo, piněndarangeng-e. Tangú Ansuang e saụewe éne, tangú i sie nẹ̆berạe: "Be! pĕnnad' i Waha kai mahamụ; kai kinoa kerea?" Angkûng i Waha u kai nitĕmpelang u uase mahamụ. Ansuang e něberạe: "Siạ koạko lại kere? "Angkn̂ng i Waha u: "Iạ botongewe makakoạ.." Tangú Waha e mĕngkate nẹ̆tongkạ u sẹ̆sal̨eng sĕmbua, su pananẹ̆saļeng, niapakahamụ. Tangú Waha e nẹ̆berạe su Ansuang e: "Kai hẹ̆do 'hepesang su papěhaseng kal̦amona, mapia 'pěndẹ̆kateng e." Ute Ansuang e mĕngkate nẹ̆tĕngkataho su papěhaseng, bọue' i Waha mĕngkate namasị u sẹ̆sal̦eng si Ansuang e, woue' i sie timą̧ang kụ naiang su wiwih' u pahighi. Tangú angkûng i Ansuang u: "Be! i kau e Waha! bọu nangakaḷ̆ sạa, èng! kụ iạ e wẹ̆dị matẹe." Angkûng i Waha u: "O, harusẹ̆! bẹ̆dị piạ tau timal̦ang tarạ̣ kere, 'pakịbalôngku, kai tawe simimbang." Angkûng i Ansuang u: "I kau kai mělẹ̆hapa apa?"

"Mëlẹ̆hapa pahighin Bawụku."

Angkûng u Ansuang e u: "Iạ mĕndenọko."

I Waha nẹ̆bera u: "Iạ tamẹ̆gèllị, u kai 'pẹ̆berâng i Wawụku." Tala, i Ansuang e tawe nahimang, mëngkate timumpa nĕndenọ, 
kutẹu uase su rạung $\mathrm{u}$ wadang u Ansuang e simẹ̆bụe; kutẹu natẹ́e, i Ansuang, kụ i sie kinaaką̣engken Baha, wọu nangĕnsue kinạ i sire tinapa.

Nahẹ̆pusẹ̆.

\section{VERTALING.}

Verhaal van den Aap, den Tijger, de Kat en de Geit.

De Aap had tot slaven den Tijger, de Kat en de Geit. Hun huis stond dicht bij de kust. De Aap nu had een werpnet, en hij en zijne slaven wekten elkaar op om te zamen te gaan visschen. Het overschot nu van hun vischmaaîtijd werd gerookt. Den volgenden dag gingen zij weder visschen en spraken er over, wie het huis zou bewaken. De Kat zeide: "Laat mij het huis bewaken." Onder den drup nu van liet huis lag een groote omgevallen boomstam. De Aap zeide: "Probeer gij eens, Kat, om den boomstam op het erf te gooien." Toen krabde de Kat aan den stam en haalde er heele stukken uit. Toen zeide de Aap tot de Kat: "Bewaak gij het huis maar, Kat!" De anderen nu gingen naar het strand om te visschen.

Toen de visschers vertrokken waren, was er plotseling iets dat klotste, en het kwam nit het woud; wanneer het tegen een boom stiet, dan brak die in stukken, en kwam het tegen een steen aan, dan vloog die er uit. En het was een Reus. Bij zijne komst groette hij de Kat; daarop naderde de Reus de rook-vliering en at van de visch. De Kat nu trachtte hem weg te werpen, maar daar hij hem niet kon wegwerpen, krabde hij daarop den Reus en krabde hem boven van de dij en hield pas op beneden aan de kuit, het vleesch ging er in heele stukken af. De Reus zeide: "Krab maar toe, Kat, wij zullen pas met elkaar worstelen, als ik klaar ben met eten." Toen hij had opgehouden met eten, gaf de Reus de Kat een slag met de hand; de Kat werd zeewaarts opgeworpen; daarop zwom de Kat maar weer naar land, en door den Reus weggeslingerd zijnde des morgens, kwam zij pas terug toen het 
meds avond was gewowlen. Toen sỉ op het strand was gekman, ging zij weler op naar het hais.

Toen de Kat thuis gekomen was, kwamen de vissehers an. " $\mathrm{Fr}$ is iets gebeurl, Heer, nwe nu onze rook-vliering is zon even door een Reas bezooht; die heef mÿ in de zec geworpen en ik ben nn ook maar pas weer thuis gekomen, nit zee weer hiowwen gezwomman zinnde, * Toen seide de Geit: "Lat mij morgon op het huis passen." En den volgenden dag weder seide de Aup tot als

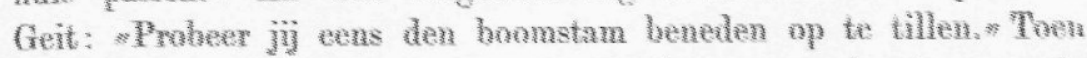
nam de Geit dien boomstam op de horens en danste er mede heen-en-weer. Daarop lieten de anderen de Geit achter om het huis te bewaken, en daalden af naar het strand om weer te vissehen.

Nadat zij aan het vissehen gegaan waren, kwam plotscling de Reus weder an 't huis en meteen was hij op de rookvliering der vissehen en at ze op. Toen stiet de Geit den Reus, on sleehts het vleeseh van den Reus stiet hij er bij stukken af. Toen zeide de Rens: "Stoot maar, Geit, ik zal 't $n$ betaald zetten nadat ik gegeten heb." Toen hij klaar was met eten, gaf de Reus de Geit een slag, en deze werd in een boog in zee geslingerd. En daarop kwam de Geit aanplassen en kwam pas thuis, tegelijk met degenen, die uit visschen waren geweest. De Geit zeide tot degenen die gevischt hadden: "Wat is er over Heer, van de visch op de rookvliering; de Reus is straks weder gekomen en meteen was hij ook op de rookvliering." Toen zeide de Tijger: "Wacht maar, laat mij morgen het huis eens bewaken."

Den volgenden dag nu bewaakte de Tijger het huis, en nadat de visschers weggegaan waren, kwam de Reus plotseling weder en was in een wip weder op de rookvliering. Toen trachtte de Tijger den Reus op te tillen en weg te gooien. Toen hij al opgenomen werd zeide de Reus: "Wacht, totdat ik gegeten heb," en daarna wierp hij ook den Tijger weg, en het ging hem ook evenals de Kat en de Geit.

Toen zeide de Aap: "Gaat gij af naar 't strand om te visschen, ik zal het huis bewaken." Daarop hoopte de Aap veel hout op en warmde er zich aan. En daar was de Reus weder en zeide: "Wel wat zijn die apen-billen rood, hoe is dat gedaan?" De Aap zeide: "Er is een rood ijzer tegen aan gehouden." De Reus zeide: "Doe het mij ook eens." Toen zeide de Aap: "Ik kan het wel doen." Daarop maakte de Aap een stuk ijzer heet op de kolen in de smidse, en liet het rood worden. En de Aap zeide tot den Reus: 
"Gij zult eerst geklemd worden in de pers, dan wordt het goed geplakt." Daarop ging de Reus in de pers en toen plakte de Aap het smeedijzer op den Reus en vluchtte weg en zette zich op den rand van een put. Daarop zeide de Reus: "He, jị Aap, je hebt mij bedrogen, he? Ik heb een gevoel, dat ik sterf." De Aap zeide: "O, dat komt uit, ik bemerkte dat iemand dáár naar boven vluchtte; ik heb hem gevraagd, maar hij antwoordde niet." De Reus zeide: "Wat bewaakt gij daar?"

"Ik bewaak den put mijner Meesteres".

"Laat mij een bad nemen", zeide de Reus.

"Dat sta ik niet toe", zeide de Aap "want dan word ik beknord, door mijne Meesteres."

Maar neen, de Reus gehoorzaamde niet en sprong naar beneden om te baden, en het ijzer in het lichaam van den Reus schuimde en de Reus stierf en zoo werd hij, die hunne gerookte visschen had opgemaakt, bedrogen door den Aap.

Einde.

\section{AAN'TEEK ENINGEN.}

Dit verhaal heeft het laatste gedeelte met II (en vooral met de lezing f) gemeen. Daarom heb ik 't hier laten volgen.

Tẹ̆tạ-e is waarschijnlijk navolging van 't Mal. sabĕrmula aan 't begin van verhalen. Het wordt op deze wijze zelden gebruikt, wel vindt men gewoonlijk aan het slot der verhalen nahẹ̆pusẹ̆ "t is geeindigd". - Matjan is de uit het Jav. in 't Moluksch Maleisch overgenomen vorm; naar de Sangireesche uitspraak wordt het masang, 't welk wij ook boven (bl. 391) vinden. su honda beteekent: in de goot die door het water dat van 't dak druipt, op het erf gevormd wordt - kĕnnangko pĕhipen ; de Aap onderwerpt zijne slaven eerst aan een krachtproef, om te zien, of zij 't huis kunnen verdedigen - pẹ̆sempare; de stam pare (mam.) bet. "hout hakken", kalu sĕmpare "een stuk gehakt hout", pẹ̆sĕmpare "telkens een stuk, zoo groot als er 
met een hak afvliegt, bị heele stukken", n.l. nangah ụ "krabde hij er af."

Matangga su kalu, enz. behoort tot de vaste dingen, die van de Reuzen verteld worden, ook in de verhalen II komt het voor. Het verschil tusschen matangga en mitangga is zeer gering, 't eerste is "stooten tegen" (intr. passief), 't tweede "komen te stooten tegen, in onzachte aanraking komen met" (accidenteel). De boomen zou de Reus kunnen vermijden, dus daartegen stoot hij met meer opzet dan tegen de steenen, die in den grond liggen. - paha is de naam van eene horde, die gewoonlijk aan eenige touwen boven de stookplaats hangt en waarop alles gelegd wordt, dat men wil rooken. 't Is zeker een der oudste stukken huisraad der M. P. volken, want het woord komt in bijna alle talen voor. Zie Brandes, Proefschrift bl. 46, 47. - mĕhipe is een voorbeeld van de conatieve bet. van 't Futurum. Dat een duratieve vorm zulk eene bet. heeft, is op zich zelf natuurlijk; zie ook Kern, Kawi-studien, bl. 36, 37 en vgl. hierboven, bl. 345. — s a in g, de stam der uitdrukking pẹ̆sĕnsaing, moet wel "afgescheurde reep, gedeelte" beteekenen. Het komt overigens niet voor, wel saị (zie S. Spr. bl. 35), in de uitdrukkingen saị pakẹ̆sa, saị karuane, saị katĕlune, benoemingen van den $17^{\text {den }}, 18^{\text {den }}$ en $19^{\text {den }}$ dag der maan-maand. Vgl. ook sahing en sahe.

Sasongo "tijd, wijze van thuiskomen" (zie bl. 68), hier te vertalen met "thuiskomst". — salo (sum.) bet. "een krijgsdans uitvoeren" (tjakalele); "dansen" (mĕnari) is salai (mẹ̆s.) mamamẹ̆da is den stam pẹ̆da, en heeft niets met meda "tafel" te maken. De stam kan samenhangen met pẹ̣di; zie boven bl. 325, r. 14. Het is een Sasahara-woord, dat in scherts gebruikt wordt.

Sẹ̆saḷeng sĕmbua "een stuk ijzer, waaruit één peda kan gesmeed worden." Zie hierboveu, bl. 389. - Over 't gebruik van harus ẹ̆, zie bl. 187 . 
IV.

De beide volgende verhalen (IVa en IVb) zijn feitelijk dezelfde, behalve dat de tweede persoon bij a de Reiger, bij b de Setan is. Daardoor is de afloop dan ook eenigszins verschillend, maar de gelijkheid is toch te groot, om ze niet onder één nummer te brengen.

IVa.

\section{BIO, PIA I WAIIA REDUAN BAHOA.}

Humotong piạ i Waha, rĕduan Bahoa mẹ̆tẹ̆tataedẹ tawe mẹ̆tikị, kutẹu kạkaḷoarane hẹ̆bi, tangú i Wahoa kai mạponggen tikị. Kái i rĕdua mĕbẹ̆bataru kerene, kai i rèdua man mẹ̆tẹ̆tĕngo. Tangú angkûng i Waha u: "E! ẹ! i kau Wahoa, kai sen mẹ̆tẹ̆tikị!" Kutẹu pelẹesan Bahoa e u: "Tala Waha! iạ tawe mẹ̆tatikị; iạ e kai mẹ̆pẹ̆patadụ kinạ ĕndạ̣ su lantehẹ̆ku, u mẹ̆deạu kai takụ kinaseng; bẹ̆dị kai sen napolong tą̣oarane." I rĕdua man lụ̣ahowọ su wowon batang su moade. Tangú tikị i Wahoa nasaḷiwuhẹ̆ kạpia, watụ kawe niwokâng i Waha.

Kutẹu, sěngkĕlěndịewen i Waha pai semben mẹ̆pẹ̆paimbon tikị. Angkûng i Wahoa e u: "k! ẹ! i kau, Waha, kawe sen mẹ̆tẹ̆tikị!" Angkûng i Waha u: "Iạ tawe mẹ̆tatikị; iạ kai kụkiling u ḷuạ ĕndạ̣ tawe tau mananuhudẹe, o kawe ḷ̣̣lunggi." Tangú i rĕdua saụ narĕmmasẹ̆, mạhungkaiang su wowon batang. Kutẹu sĕngkakĕlla pai i Wahoa semben mẹ̆pẹ̆patadụ. Kinasilon Baha: "E! ẹ! i kau Wahoa, kai sen mẹ̆tẹ̆tikị!" Sinimbangkewen Bahoa e u: "Tala, Waha, iạ kai kụkiling, u pĕnnad' i Waha tawe tau nanguno su same, o kawe mahamụ." Nẹ̆sạ̣ narĕmmasẹ̆ i rĕdua. Kutẹu sĕngkakĕlla pai i Waha semben mẹ̆pẹ̆paimbo. Kinasilon Bahoa e: "Kate, 
kate kai, Waha! i kau kai sen katikịe?" Angkûngkewen Baha: "Tala Wahoa; iạ kai kụkiling u l̦ehẹ i Wahoa: tawẹ tau namoḷeng, o kamageng manemọ kinạ kawe mạĕndadẹ̆·manandu." Saụ narĕmmasẹ̆ i rĕdua. Kaiso hẹ̆bi e karạ̦ung e, aramanung semben pukuḷẹ ẹ̣ạ. Sěngkakěllan Baha pai i Wahoa semben mẹ̆pẹ̆patadụ u tikị, dokẹewen bawĕllo i rĕdua mang mạhiang tanĕmpẹ̆tikị sarang kadodọ.

Kutẹu angkûng i Waha: "Kate, kate, Wahoa! i kau semben mẹ̆tikịe, ute i kau sen ěllangku." Sinimbang u Wahoa: "E Baha! kapapiako wue araụ! iạ tawe nẹ̆tikị, u iạ e kai mẹ̆pẹ̆patadụ e u kai mạdą̣ingun kĕmpughang, tawẹ tau nanina, o kawe mitung." Tangú, ěllo e sen mạtualagẹ̆, sen namukuḷẹ̆ ĕnnung u mal̦ukadẹ̆.

Ene, saụ narĕmmasẹ̆ kere, i rĕdua tangú sĕngkakĕllan Bahoa pai i Waha semben sạ̣ mẹ̆pẹ̆paimbo. Kinasilon Bahoa: "Heute, ĕng, Baha! i kau kanini sen mạnĕllid'u iạ 'anuang ĕllang-u, watụ iạ kai mạdạ̧ingun kĕmpughang, tawẹ tau nanina, o kawe mitung, ute i kau kawe ěllangku." Angkûng i Waha e u: "Kate kai! i kau kai sen mĕbẹ̆bera kerene si siạ e! lahạu iạ kawe nẹ̆tikị! Iạ kawe kụkiling u larang, tawẹ tau nangěhabẹ̆, mase kai mahoro, kụ mẹ̆nsang kai sanggidang bọu kaihi, arau wọu koaneng." Tangú i rĕdua mĕngkate mĕdẹ̆darendehẹ̆. Angkûng i Waha, i Wahoa kai anuang ěllang-e. Angkûngkewen Bahoa i Waha kai ěllang-e. Tangú sarang i rĕdua mĕngkate mĕdẹ̆darendehẹ̆, kụ i Wahoa tate makarendehẹ̆ si Waha, tangú i Wahoa mĕngkate sĕngkianu timěllạ, batụ sen ěllo. Uté sagurang i Waha mĕngkate kụkakĕlla su langị maļoang, mĕnsang Bahoa e kai saụ dumorọ suapa. Kai Wahoa e semben tawe rimorọ, kaiso sasaẹ timĕllạ soḷong pûng u lạngị.

\section{IVa. VERTALING.}

\section{Verhal van den Aap en den Reiger.}

Er was eens een Aap en een Reiger, die het tegen elkaar uithielden om niet te slapen. Te middernacht begon de Reiger te knikkebollen van slaap. Aldus weddende, zaten zij tegenover elkaar. Toen zeide de Aap: "Zoo Reiger, slaap je al? maar de slimme 
Reiger antwoordde: "Neen Aap, ik slaap niet, ik knikte tegen dien visch, daar vóór mij, want ik wilde hem opeten, het was mij alsof ik hem al middendoor gebroken had." 'Lij beiden zaten gehurkt op een omgevallen boomstam, op een zandbank. En de slaap van den Reiger was overgegaan, omdat hij door den Aap was toegeroepen.

En plotseling knikkebolde de Aap weer van den slaap. Toen zeide de Reiger: "Zoo, zoo Aap, gij slaapt al!" De Aap zeide: "Ik slaap niet, ik schudde er mijn hoofd over, dat deze golven door geen mensch worden voortgestuwd, en toch voortwentelen."

Toen werden zij beiden weder stil en zaten op den omgevallen boomstam. En zie, daar knikkebolde de Reiger alweer. Toen de Aap dat zag zeide hij: "Zoo zoo, Reiger, gij slaapt reeds!" De Reiger antwoordde: "Neen Aap, ik heb er mijn hoofd over geschud, dat de billen van den Aap door geen mensch zijn ingedoopt in same, en toch rood zijn!" En wederom werden zij stil. Plotseling knikkebolde weder de Aap. Toen de Reiger dat zag, zeide hij : "Wel zoo Aap, slaapt ge al?" De Aap zeide: "Neen, Reiger, ik schudde mijn hoofd over den hals van den Reiger, niemand heeft hem uitgerekt, en toch als gij visschen pikt, kan hij zoo lang uitgerekt worden." En weder waren zij beide stil. Het was in 't holst van den nacht, misschien was het reeds 4 uur, toen plotseling de Aap zag dat de Reiger weder knikkebolde van den slaap, want van des avonds af zaten zij bij elkaar, en sliepen in het minst niet.

Toen zeide de Aap: "Ziet ge wel, Reiger, gij gaat alweer slapen, dus zịt gij mijn slaaf." De Reiger antwoordde: "Hoe, Aap, wacht er eens, ik heb niet geslapen, maar ik schudde mijn hoofd, want ik verwonderde mij over de Gumutu, niemand heeft ze zwart geverfd en toch is ze zwart!" Toen was het klaarlichte dag geworden het sloeg reeds 6 uur in den morgen.

Ein terwijl zij aldus weder stil waren, zag de Reiger weder den Aap knikkebollen en zeide: "Zie zoo, Aap, gij hebt zoo straks al de hand op mij gelegd, om mij tot uw slaaf te makeu, omdat ik mij verwonderde over de Gumutu, die door niemand is zwart geverfd en toch zoo zwart is, maar gij zijt mijn slaaf." De Aap zeide: "Wacht eens even, spreekt gij reeds zóó tot mij, alsof ik geslapen had! Ik schudde mijn hoofd over den priem, dien geen mensch heeft gescherpt en die toch scherp is, en dacht er over hoe men hem naderen moet, van links of van rechts.

En zoo spraken zij elkander tegen. De Aap zeide, dat de Reiger 
zijn slaaf was geworden, maar de Reiger zeide, dat de Aap zijn slaaf was. En toen zij beide zoo redetwistten, kon de Reiger het niet volhouden om tegen den Aap te redetwisten, en toen vloog de Reiger plotseling op, omdat hét reeds dag was. Die goede ziel van een Aap keek in de lucht, verlangend te weten waar of de Reiger zou gaan nederzitten. Doch de Reiger ging niet zitten, maar vloog op naar den horizont.

\section{IV $a$. AANTEEKENINGEN.}

Van humotong geldt 't zelfde, als boven (bl. 394) van tẹ̣tạ-e gezegd is. - dĕdua is een geredupliceerde vorm van $\mathrm{dua}$, die als tweevoud van i sie gebruikt wordt, zie bl. 236. Men gebruikt dezen vorm gewoonlijk als verbindend voegwoord, van twee personen sprekende, die zich in elkaars gezelschap bevinden; de verbindende n koint dan na dĕdua, bv. i Andreas dĕduan Jakobus "A. en J." Komt er nog iemand bij, dan voegt men diens naam gewoonlijk aan met 't drievoud i sire těllu, gevolgd door de n en den naam, bv. i Andreas dĕduan Jakobus, i sire tĕllun Petrus "A. J. en P." woordelijk: "zij drie, door P." Dit gebruik om bij een klein aantal personen het getal er bij aan te geven, door 't gebruik van 't twee- en drievoud der pers. voornaanwoorden, wordt soms nog uitgebreid tot het voegen van de telwoorden, tot 10 toe, bij het meervoud. Zie bl. 239. - De grondvorm van mẹ̆tataedẹ̆, taedẹ̆, bet. "strak, gerekt", bv. tumingang mataedẹ̆ "strak kijken". Vandaar de bet. van mẹ̆tataedẹ̆ "om het langst", bv. mẹ̆t. murung "om het langst duiken, het duiken tegen elkaar rekken." - pelẹesa bet. "handigheid, slimheid", er staat dus: "en de slimheid van den Reiger antwoordde," of: "en verbeeld U de slimheid van den Reiger." In 't Jav. is deze constructie een vaste syntactische regel.

$\mathrm{Same}$ is de verfstof, die van den bast der rhizophoren (lolaro) wordt gemaakt en die ook als looiwater wordt gebruikt. - Naast ĕndadẹ̆, maĕndadẹ̆ "lang vitgerekt worden", komt voor in de zelfde bet. bĕndadẹ̆, mawĕndadẹ̆. - kĕmpughang zijn de vezels van den aren-boom, waaruit gumutu-touw gedraaid wordt. 
Hier makt de Reiger een toespeling op de haren van den Aap. - anuang is een passieve vorm van manganu, in plaats van i anu, van den stam anu. Over dit woord, zie bl. 252. Men kan het w. w. manganu voor ieder ander gebruiken, daar het beteekent: "dinges doen", hier "maken tot", zooals uit 't verband blijkt. Maanu heeft den zin van "bedoelen". - larang is juist zulk eene aardigheid als $\mathrm{kĕmpughang} \mathrm{boven.} \mathrm{Hier}$ wordt er schertsend de bek van den Reiger mee bedoeld. - s a g u ra ng van den stam gurang "oud" met het voorvoegsel sa (bl. 135), wordt vriendelijk of medelijdend gebruikt, in den zin van ons: "die goede ziel, die arme stakkerd", ook wel in zijne eigenlijke bet. van "oudje". - pûng bet. "stam", zooals ook in de verwante M. P. talen, en overdrachtelijk "begin". 'Zie ook 't boven, op bl. 346 gezegde. Met pûng u langị of pûng u laudẹ wordt bedoeld de gezichteinder, waar zee en hemel elkaar schijnbaar raken en die dus zoowel "begin van de zee", als "begin van den hemel" kan genoemd worden. 
IVb.

\section{BIO, PIA I WAHA R. I SETANG.}

Humotong piạ i Waha r. Setang nĕmpẹ̆darendehẹ̆ kụ tawe nĕmpẹ̆tikị arẹ̆gan sĕhẹ̆bi. Tangú i rĕdua mĕngkate mạhungkaiang dokẹewen pukuḷẹ ĕnnung bawěllo sarang pukuḷ̣̆ mapuḷo hẹ̆bi. Kụ i rĕdua ene mĕmpạhiang su kĕhu.. Tangú orase mapuḷo, kate sĕngkakěllan Setang e, i Waha kai kụkakurung, u kai sen meẹ̆tẹtikị. Tangú i Waha e nịtatělliden Setang e su poḷoh'-e, r. i Setang nẹ̆bera u: "Ellangku, i kau, watụ i kau kai sen mẹ̆tẹ̆tikị!" Tangú i Waha e nẹ̆berạe u: "Kẹ! hẹ̆doko, Setang! kapiako manĕllid' u iạ; d. iạ tawe mẹ̆tatikị, iạ kụkakurung kere ini, kai kụkakurung mạngĕnna: "Kĕmpughang tawẹ tau nanina o kawe maitung." Tangú Setang e saụewe simohọ naiang.

Sarạeng mĕngkate mạiang, ĕndịu kai sen pukuḷ̣̆ mapuḷo-ẹ̆sa, Waha e mĕngkate sĕngkianu sạ̣ kimakurung, u nẹ̆tikị e wue. Tangú Setang e saụewe timĕmbo si Waha, r. nẹ̆bera u: "E! ěllang-ku, i kau, Waha! kuhạe i kau mẹ̆konti, u sen mẹ̆tẹ̆tikị!" Tangú i Waha saụewe nẹ̆bera u: "Kẹ! Setang! kapiako i kau manĕllid' u iạ, u iạ baḷinewe kụkakurung mẹ̆tẹtikị, iạ kai kụkakurung mạngěnna $\mathrm{u}$ : tain kambing tawẹ tau nĕndụ̣ o kawe mą̣imbolong." Tangú Setang e nahimangke wue, r. nẹ̆bera u: "Ore ĕng! těngadẹ lai." Bọue' Setang e simohọe wue, kụ naiangke. Kutẹu i rědua e mĕngkate mạiang, ěndịu pukuḷewe mapuḷodua, Waha e saṇewe kụkakurung. Tangú Setang e saụewe timĕmbo, r. nẹ̆berạe u: "Ellangku, i kau; u i kau sen mẹ̆tẹ̆tikị. Kutẹu Waha e saḷạewe limendạ matane, ěndaị nẹ̆pẹ̆tị bọu kụkakurung, d. nẹ̆bera u: "Kẹe, Setang! kapiako manĕllid' u iạ; bal̦inewe kụkakurung mẹ̆tẹ̆tikị, dokeng kanini kai kụkakurung mạngěnna." Bọue' Setang simohọewe naiang $d$. nakiwal̨o $\mathrm{u}$ : "Apạete wue, pangangènanu?" Angkûng u Waha, u: "Luạ tawẹ tau mĕlą̧unggi, o kawe lụ̣unggị." Tangú Setang e saụewe simohọ naiang su 'kẹ̆kaianeng-e. Marĕngụ, ěndịu kai sen masanggidẹ̣ mamukuḷ̣̆ sĕmbaụ, o i 5e Volgr. Vill. 
Waha e mĕngkate mẹ̆ginggen tikị e. Tangú i Setang e saụewe timĕmbo r. naněllidẹ̆ poḷoh' i Waha r. nẹ̆bera u: "Eute, i kau mamben sen ěllangku, Waha! sen tamakapẹ̆děndilẹ̆." Tangú i Waha e saụewe limigọ, u himẹ̆kosẹ̆, d. nẹ̆bera u: "Kapapiako, Setang!" Tangú Setang e simohọewe naiang d. nẹ̆bera u; "Apạe wue, Waha! 'pangangĕnanu?" Sinimbang i Waha u: "Akụ, makạingge siạ doken kanini e u, mĕngkai mẹ̆gingge mạngĕnna, mĕnsang haungang bọu kaihi, arau haungang bọu koaneng." Tangú Setang e nakiwalọe wue, ute Waha e simimbangke: "Akụ," angkûng-e, "larang tawẹ tau nangěhabẹ̆, o kawe mahoro." Simohọ kạpia Setang e r. nẹ̆bera n: "Eị! tĕngadẹ̆ lai, o!" I rĕdua mĕngkate mạiang; tangú Waha e semben napia, ihạ-e, arawe Setang e sen lotahẹ̆ masaria ene, u Setang e tawe nẹ̆tẹ̆tikị, doken bawĕllo. Baha e semben tawẹ pĕndang-e mẹ̆tikị u sen nạun bọu mạngapidẹ̆ mĕtẹ̆tikị tĕntaļang i rĕdua ěndạ̣ mạhiang. Tangú i rĕdua mĕngkate marĕngụ mạiang, kutẹu sarạeng pukuḷẹ lima man bẹ̆dang mạiang, o Setang e kinahuntikilangke; tangú Setang e tinĕmbôngken Baha r. nitěllid-e su ĕntana, apid'u niasa su ĕntana, r. nẹ̆bera u : "Ellangku i kau!" Tangú Setang e tawe nakareạ hingid-e apa, kụ kai kinauntungang i Waha. Tangú Setang e nariadi ěllang i Waha, sarạewen ini ; kái uade Setang e mamben su aḷung i Kạ Baha, mĕngkai nawoidạ, i rĕdua wọu nĕmpẹ̆darendehẹ̆ arẹ̆gan sĕhẹ̆bi tawẹu nĕmpẹ̆tikị.

Nahẹ̆pusẹ̆.

IVb. VERTALING.

\section{De Aap en de Setan.}

Er waren eens een Aap en een Setan, die het tegen elkaar uithielden om niet te slapen gedurende een nacht. En zij beiden zaten van 6 uur af in den avond tot 10 uur in den nacht en zij zaten in het woud. En om 10 uur zag de Setan dat de Aap gebukt zat, want hij sliep reeds. En de Setan legde zijne hand op den nek van den Aap en de Setan sprak: "Gij zijt mijn slaaf, omdat gij reeds slaapt." Maar de Aap zeide: "Ho, wacht eens even met de 
hand op mij te leggen; en ik sliep ook niet; aldus voorover zittende, zit ik in overpeinzing hierover: "de gumutu heeft niemand zwart geverfd en is toch zwart!" Toen ging de Setan weder achteruit en zette zich neer.

Terwijl zij voortdurend zaten, het was misschien ongeveer $11 \mathrm{uur}$, boog zich de Aap plotseling weder, want hij sliep weer in. Toen viel de Setan weder op den Aap aan en zeide: "Gij zijt mijn slaaf, Aap, houd op met liegen, want gij slaapt reeds." Toen hernam de Aap: "Hei Setan, wacht eens even met de hand op mij te leggen, want ik heb mij niet gebogen om te slapen, terwijl ik gebogen zat dacht ik: "geitenkeutels heeft geen mensch gedraaid en toch zijn ze rond!" De Setan geloofde het weer en zeide: "Ja, dat is waar ook!" Daarna ging de Setan weer achteruit en zette zich neer. En zoo zaten zij weder tot ongeveer $12 \mathrm{uur}$, toen de Aap wederom gebogen zat. De Setan vloog weder op hem aan en zeide: "Mijn slaaf zijt gij, want gij slaapt reeds." En de oogen van den Aap, glansden om zoo te zeggen, toen hij zich wit zijn gebogen houding oprichtte en hij zeide: "Ho, Setan, wacht eens even met de hand op mij te leggen; ik heb mij al dien tijd niet gebogen om te slapen, maar ik zat gebogen in overpeinzing." Toen trad de Setan terug, ging zitten en vroeg: "Wat was dan weer uwe gedachte?" De Aap zeide: "De golven rolt niemand voort en toch wentelen ze!" Toen ging de Setan weer terug en zette zich op zijn zetel neder.

$\mathrm{Na}$ geruimen tijd, ongeveer bij één uur, waggelde de Aap van slaap; toen vloog de Setan weder op hem aan en greep den Aap bij den nek en zeide: "Zie zoo, nu zijt gij bepaald reeds mijn slaaf, Aap, gij kunt het niet meer ontkennen." Toen keek de Aap) wederom met groote oogen rond, want hij schrok, en hij zeide: "Wacht eens even Setan!" En de Setan trok zich terug, ging zitten en zeide: "Wat was dat Aap, waar gij aan dacht?" De Aap antwoordde: "Dat ik van straks af het bovenlijf heen en weer schudde, was omdat ik schuddende dacht of ik zou moeten naderen van de linkerzijde of wel van de rechterzijde." En de Setan vroeg nog verder en de Aap antwoordde: "Omdat de dorens door niemand gepunt zijn en toch scherp zijn!" Wederom ging de Setan achteruit en zeide: "Ja, dat is waar ook!" Zij zatén voortdurend en de Aap was reeds weer opgefrischt, maar de Setan was reeds zeer slaperig, want hij had niet geslapen van des avonds af. De Aap had geen gevoel van slaap meer, want hij had al tussehen de bedrijven door geslapen, terwijl zij daar zoo bij elkander zaten. Langen tijd nu 
zaten zij daar, en toen zij om 5 uur er nog steeds zaten, viel de Setan in slaap. Toen vloog de Aap op hem aan en drukte hem met de hand ter aarde, hem tevens over den grond wrijvende en zeide: "Gij zijt mijn slaaf." De Setan nu kon geen bedenksel vinden en werd door den Aap overwonnen. Zoo werd dan de Setan de slaaf van den Aap, tot op dezen dag, en men zegt dat de Setan wel zeer onder den Aap zat: hij was tot zijn schade bedrogen, nadat zij het gedurende één nacht met niet slapen tegen elkaar hadden willen uithouden.

IV . AANTEEKENINGEN.

Mĕnsang 'haungang bọu kaihi, enz. Hier is de verhaler een weinig in de war en hij tracht dit eenige regels verder te herstellen. Voor de juiste lezing zie men boven, bl. 397. - manngapidẹ̆ "in 't voorbijgaan doen, en passant meenemen." M angapidẹ mẹ̆tikị "tusschen 't andere werk door slapen, onder de bedrijven een dutje doen." - kinahuntikilang is van 't infix in ontdaan, een n. w. lijke vorm van mahuntikị "slaperig", dus kin a h. "ingeslapen" is letterlijk "door slaperigheid overvallen". Vgl. bl. 129. - Van mawoidạ is de beteekenis: "door bedrog schade lijden, bedrogen uitkomen." 
BIO PIA I WAHA R. WUALA.

I Waha sasaẹ nangĕmpuhe. Kutẹu kûng u Wuala e: "Mapia sasaẹ i kadua!، Kûng u Waha e: "Mẹ̆deạ kinạ i kadua kima." "Ho!" kûng u Wuala e "sasaẹe wue!"

Sarang i rĕdua su saghẹ, kutẹu i rĕdua nakaĕbạe kima. Kûng u Wuala e: "Koatengke kereapa ene, kai nahepes' u watu?" Kûng u Waha e: "Kokọkon ḷimanu." Ené Waha e sen kạkontine su Wuala e. Ho, Wuala e mĕngkatewe nangokọ. Sarang nangokọ, su pělahepes' u kima e. Kûng u Wuala e: "I kau kai nangakaḷ̣ si siạ! Pahẹ̆do! i kau takụ kinaseng." "Ore", kûng u Waha e: "i kau sen mĕlewa", kụ Baha e mĕngkatewe timą̧ang, nariadi liman Buala e, tą̣imẹ̆done e, nasue napentehẹ̆. Ho, Wuala e mĕngkatewe lighạ nanahusu Waha e, suapan Baha e sen nakatalang marau. - Buala e sen tanakaĕbạ Baha e.

Sarang nararĕnạe kadodọ, kutẹu Waha e kai saụ nangĕmpuhe, rimarisị su hamụ u pahẹ̆pạ. Sarang kinasilon Buala e, Wuala e mĕngkatewe timĕmbo, nikikine su laed-e. Kareạu kapelẹesan Baha e i sie nẹ̆bera: "Be, Wuala! i kau wą̣inewe timěmbo siạ, kai timĕmbo wakọ." Uté Wuala e namĕllọe. Ené Waha e mĕngkatewe kimẹ̆se su kotọ u pahẹ̆pạ. Kûng u Waha e: "Buala e kinakontiangke wue!" Ho, tarạ̣ dimakị su sĕngkalu, natẹ̆pas' u wą̣ene. Sarang kerenẹ́e, i sie mĕngkatewe nataraị soḷong sasuang-e, nangaḷa busạ sĕngkalu, wọu ene $\mathrm{i}$ sie mĕngkatewe sasaẹ nẹ̆bạ̣i soḷong balene. Kai naung u Waha e man tawe matarimạ, batụ u mạtakụ u Wuala e. Bọu matakụ saụbe matarimạ, batụ makạtahëndung balene. Ho, i sie mĕngkatewe nasasaẹ. Kûng u Waha e: "Bą̧eku e sụsimbahẹ̆, mạeng iạ mẹ̆gĕllị u tabeạ. Mạeng tasumimbang, kai Wuala ene." Ho, Waha e mĕngkatewe nẹ̆gĕllị u tabeạ, kûng-e: "Tabeạ, bal̦e!" Sĕngkělĕndịu simimbang. Kûng u Waha e: "Tawe pulu, wą̣e sumimbang; ene kai Wuala e, sen nĕhapa wal̨eku. Ho!" kûng u Waha e "koạe wą̣enu! Iạ mangą̣ing su wą̣ine." Sěngapau dĕngụ-e Wuala e sen tanakaĕbạ Baha e. 


\section{VERTALING.}

\section{De Aap en de Krokodil.}

De Aap ging eens schelpdieren zoeken. Toen zeide de Krokodil: "Laat ons te samen gaan." De Aap zeide: "Wij zullen eene reuzenschelp voor voedsel zoeken." "Goed" zeide de Krokodil "laat ons dan naar 't strand gaan."

Toen zij op de riffen waren, vonden zij eene reuzenschelp. De Krokodil zeide: "Hoe zullen wij doen, het dier is tusschen de steenen geklemd!" De Aap zeide: "Pak het met uwe handen aan!" Hier bedroog de Aap den Krokodil. De Krokodil pakte het daarop met zijne handen aan. Zoodra hij dit gedaan had, werd hij door de reuzenschelp gekneld. De Krokodil zeide: "Gij hebt mị bedrogen! wacht! ik zal u opeten." "Ja", zeide de Aap, "gij gaat mij al likken", en de Aap vluchtte daarop heen, waardoor de hand van den Krokodil, al zijne vingers, werden afgekneld. Daarop zette de Krokodil vlug den Aap na, maar de Aap was reeds ver weg gevlucht. De Krokodil kon den Aap niet meer vinden.

$\mathrm{Na}$ verloop van eenigen tijd ging de Aap weder visschen, en ging op de wortels der rhizophoren staan. Toen de Krokodil dit zag, viel hij hem terstond aan en beet hem in zijn poot. Dank zij de slimheid van den Aap, zeide deze: "Nu, Krokodil, gij valt mij niet aan, gij valt een rhizophoorwortel aan." Toen liet de Krokodil los en de Aap sprong daarop in den top van een rhizophoor. De Aap zeide: "De Krokodil is weer door een leugen beet genomen." Daarop sprong hij van den eenen boom op den anderen en ging recht op zijn huis aan. Hierop ging hij naar zijn tuin en haalde de vrucht van een pisangboom, daarna ging hij naar zijn huis terug. Doch het hart van den Aap was maar niet gerust, omdat hij bang was voor den Krokodil. Na bevreesd geweest te zijn, werd hij weder rustig, als hij zich zijn huis herinnerde. $\mathrm{Nu}$, hij ging er maar heen. De Aap zeide: "Mijn huis antwoordt, wanneer ik het groet. Wanneer het niet antwoordt, is het de Krokodil." Daarop groette de Aap en zeide: "Dag huis!" Plotseling kwam er antwoord. De Aap zeide: "t Is niet zoo gek (zoo iets geks gebeurt er niet), dat een huis antwoordt; dat is de Krokodil, die is mijn huis reeds komen bewaken. Welnu", zeide de Aap" maak het tot uw huis, ik zal verhuizen naar een ander."

Eenigen tijd lang kon de Krokodil den Aap niet meer vinden. 


\section{AANTEEKENINGEN.}

Dit verhaal is voor 't eerst uitgegeven door Dr. Riedel en te vinden op bl. 10 van de boven (bl. 322) aangehaalde verzameling. - De bet. van ĕmpuhe is "schelpdieren en kleine visschen vangen, met een stokje en een kleine fuik (sak uh ̣̣) op de koraalriffen (saghẹ), vandaar wordt 't ook mangĕnsaghẹ genoemd. Dit geschiedt in de plassen, die bij eb in de riffen achterblijven. - De kima is de bekende reuzenschelp, (tridacna gigas), waarvan de grootste soort op Sangir als varkenstrog wordt gebruikt. - Over de uitdrukking sarang — su, zie boven bl. 360 . suapa, zie boven bl. 353. — sĕngapa "een wat, een iets, een weinig." Sĕngapan dĕng ụe is hier "langen tijd." 
Kutẹu kûng u Wuala e: "Mahi, i kitẹ mẹ̆sasuḷung u kakẹ̆paḷ" u taune!" Kûng u Waha e u: "Ho! riọello i kitẹ mẹ̆sombang su apeng." Manụ e wuhụ́e sĕngkakukụ, Baha e simĕbangke su apeng, mĕngkatewe nĕlita apeng e wọu pondoḷe sĕmpotọ sarang pondoḷe sĕmpotọ, bọue' naiang tạ kĕndị-e. Mạ̦ukade o, rimĕntạe wuala e, mĕngkatewe nahẹ̆ping, laudẹ̆ e. Kûng u Wuala e: "Kate! suapa, ringang-u e?" Kûng u Waha e u: "Kai sen tanakakẹ̆dang nahẹ̆do; kĕláewe laed-e; tamai apeng napenẹ u ěnnạ u laedẹ̆!" Kûng u Wuala e: "Kai suapa, wą̣enu e?" Kûng u Waha e: "Wawạapeng sĕmbaụ e."

Sĕngkariọĕlone Waha e nangĕmpuhe. Dụdal̦engke su moadẹ̆ e, sĕngkĕlĕndịe nitĕmbông u Wuala. Kûng u Waha e: "O, nẹ̆saḷa! i kau tawe nanẹmbo wisịku, kawe timĕmbo pahẹ̆pạ." Namĕllọe wue, Wuala e. Baha e mĕngkatewe timal̦ang, d. nẹ̆bera: "Suapawu'? kinaakaḷẹ̆! i Wuala e." Kutẹu u Waha e nakoạ soḷong lantang. Nawaḷie wawěllo. Kutẹu sarạeng masanggiden bal̨e, Waha e mĕngkatewe kimui; kutẹ tawẹu simimbahẹ̆. Baha e nẹ̆koạewe kontine: "Bal̨eku e sidutu sụsimbahẹ̆ bue; arawe íni uté kawe tasimimbahẹ̆: piạ Buala ĕndịu." Ho, nẹ̆saụewe kimui, tangú simimbahẹ̆. Kûng u Waha e: "Tạ bẹ̆ke pinintu, wale mẹ̆bẹ̆bera; Wualạe wúe, ene!"

Baha e mĕngkatewe timaļang su liang. Kutẹu kai nẹ̆sombang u Setang. Kûng u Setang e u: "Mahi, i kadua mẹ̆bataru!" Kûng u Waha e u: "Ho! mẹ̆bataru kerea?" Kûng u Setang e: "Mẹ̆bataru i kadua tamẹ̆tikị, těllu hẹ̆bi. Isain mẹ̆tikị , maĕllang." Kûng u Waha e: "Ho!" Tangú i rĕdua nẹ̆batarụ́e. Kutẹu masanggidẹ̆ kaělônge, napẹ̆pạe, Waha e. Kûng u Setang e: "I kau ĕllangku !" Kûng u Waha e: "Kapia! Iạ kai nawatang u kai mạngĕnna." Kûng u Setang e: "Kai mạngěnna kerea'?" "Kai mạngĕnna u : Kumpughang e apawe tạ tau nanina, o kawe mitung." Kûng u Setang e: "Tĕngadẹ̆, ĕng!" 
Su karua hẹ̆bine Waha e kinahuntikilangke wúe. Kûng u Setang e: "Ene, i kau ěllangku!" Kûng u Waha e : "Iạ baḷinewe mẹ̆tẹ̆tikị; iạ kai mạngěnna." Kûng u Setang e: "Kai mạngěnna a'?" "Iạ kai mẹ̆tẹ̆timbang, u larang u humbia e tawẹ tau nangĕhabẹ̆, o kawe mahoro." Kûng u Setang e: "Tĕngadẹ̆ lai!" Su katěllu hẹ̆bine Setang e nawatangke. Kûng u Waha e: "I kau ěllangku!"Setang e nakawerawen a'! - I sie nakoạ ěllang u Waha e.

Nahẹ̆pusẹ̆.

\section{VERTALING.}

\section{De Aap en de Krokodil.}

De Krokodil zeide eens: "Kom, lat ons de hoeveelheid onzer onderdanen met elkaar vergelijken." De Aap zeide: "Goed, morgen vroeg zullen wij eene ontmoeting hebben op het strand." Bij het eerste hanengekraai ging de Aap naar het strand en betrad het strand van het eene eind tot het andere; daarop ging hij stil zitten. Des morgens vroeg kwamen de Krokodillen; de zee was er door afgesloten. De Krokodil zeide: "Wel, waar zijn uwe gezellen?" De Aap zeide: "Die konden het wachten niet meer volhouden; zie maar hier hunne pooten, het strand hier is vol van humne voetsporen!" De Krokodil zeide: "Waar is uw huis?" De Aap zeide: "Daar ginds, op het andere strand."

Des anderen daags ging de Aap schelpdieren visschen. Op de landtong loopende, werd hij plotseling aangevallen door den Krokodil. De Aap zeide: "Wel, gij zijt mis!" gij valt mijn been niet aan, gij valt een rhizophoor aan." Toen liet de Krokodil los. De Aap ging terstond op de vlucht en zeide: "Wat zou het wel? de Krokodil is beetgenomen." De Aap begaf zich daarop naar den tuin. Hij kwam terug toen 't avond was. En toen hij zijn huis naderde, riep de Aap, doch niemand antwoordde. Daarop verzon de Aap een leugen: "Mijn huis antwoordt altijd, maar nu antwoordt het niet; waarschijnlijk is er een Krokodil." En daarop riep weer en er kwam antwoord. De Aap zeide: "Er is geen verhaal 
of gelijkenis van, dat een huis spreekt; 't is zeker weer de Krokodil!"

De Aap vluchtte daarop naar een hol en ontmoette een Setan. De Setan zeide: "Kom, laat ons wedden!" De Aap zeide: "Goed, hoe zullen wij wedden?" De Setan zeide: "Wij zullen wedden om drie nachten lang niet te slapen. Wie slaapt wordt slaaf." "Goed" zeide de Aap. Daarop gingen zij beiden wedden. En, toen het bijna dag was, viel de Aap er bij neer.

De Setan zeide: "Gij zijt mïn slaaf!" De Aap zeide: "Wacht eens, ik viel om van het nadenken." De Setan zeide: "Waarover dacht gij dan na?" "Ik dacht: de gumutu is iets dat niemand zwart geverfd heeft, en toch is zij zwart!" "Het is waar ook", zeide de Setan.

Den tweeden nacht werd de Aap weder door slaap overvallen. De Setan zeide: "Nu zijt gij mijn slaaf!" "Ik slaap niet", zeide de Aap, "ik denk na." "Waarover denkt ge na?" zeide de Setan. "Ik peins er over, dat niemand de dorens van den sago-palm heeft gescherpt, en toch zijn ze scherp." "Dat is waar ook," zeide de Setan. Den derden nacht viel de Setan er bij neer. De Aap zeide: "Gij zijt mijn slaaf!" Wat kon de Setan daartegen zeggen!" Hij werd de slaaf van den Aap.

Einde.

\section{AAN'TEEKENINGEN.}

Dit verhaal is eene kleine verzameling van streken door den Aap uitgehaald, waarvan er twee in de vorige verhalen (IV en V) voorkomen. Ik heb het daarom hier laten volgen.

I kitẹ mẹ̆sasuḷung, enz., woordelijk: "Wüj zullen ons met elkaar vergelijken in menigte des volks." - man ụ sĕngkakuk ụ is eene aanduiding van den tijd van ongeveer 3 uur 's nachts. mĕlita is zeker een bijvorm van mĕlinda "treden", terwịl lita bepaald voor "leem treden" wordt gebruikt. - laudẹ̆ e nahẹ̆ping is een gewone uitdrukking om eene groote menigte schepen, visschen en derg. aan te duiden. De bedoeling is: niemand 
kan er meer tusschen door varen, zoo vol is de zee er van. sĕmba ụ e, voor de vertaling, zie Sang. Spr. bl. 233.

Lantang is een tuin dien men in 't binnenland heeft en dus niet bij 't huis, dat bij de kust staat. Vandaar dat de Aap eerst 'savonds thuis komt. - simbahẹ̣ is "antwoorden op geroep", simbang op eene vraag. Zie bl. 29.

Mẹ̆bataru heeft tot stam het Mal. bĕrtaroh "inzetten, wedden", naar de Moluksche uitspraak. - mawatang is worden als een batang (omgevallen boomstam). - larang u humbia tegenover kumpughang, zie boven, bl. 400 . 


\section{VII.}

\section{BIOPI A I WAHA REDUAN UBA.}

Tangú kai piạ i Waha rĕduan Ubạ; kụ i rĕdua e mẹ̆tẹ̆tataniwe wal̦ene. Kutẹu sĕnsuḷe i rĕdua e kai nẹ̆sombang. Ené kai lai piạ dehan busạ. Tangú sarẹ̆tạu i Waha e nakasilóe rehan busạ ene, ute i Waha e ghimighile si Ubạ, bawerane: "Mahi, anu! i kadua ren mẹ̆suang u rehan busạ i kaduda." I Ubạ simimbang u: "Endạ̣ man sĕngkalu uté, anúp" Angkûng i Waha u : "Ĕbụe anu!" Tangú i Ubạ e mĕngkatewe namangkan kakudạ. Angkûng i Waha u: "Si siạ, anú, kotọ-e atụ ĕndaị e sen piạ daung-e, kụ kate manguntang kadidị, sen mẹ̆bua." Ho angkûng i Ubạ e "Anụ́e si kau; si siạ e wawạe pungene, manịen marĕngụ mẹ̆bua. Ené i Waha e mĕngkate nikahĕluaseng, baṭ̣ u si sie ĕndạ̣ sen piạ daung-e kụ i sie nẹ̆beráe: "Si siạ e isuang su sělêng, ipakisilo su sumasěllo e." Angkûng i Ubạ u: "Si siạ e isuang su rĕllahẹ̆ku, mẹ̆deạ u iạ mạtatanạbe makạsilo apan kaḷaĕllo."

Kutẹu i Ubạ e sĕngkakarumaheng-e natamạ̣e mẹ̆tẹ̆tiwo si Waha e, apidẹ̆be kụkakĕlla busạ i Waha e. Tangú i Ubạ e nẹ̆sĕmmạen Baha e su rarąlengang e sen mẹ̆tiwo wusạ-e. Angkûng i Ubạ u: "I kadudako anu! mẹ̆tiwo wusạ-u e." Kutẹu wusạ i Waha e, kai nahẹggu, sĕngkakělla. I Waha e nẹ̆beráe u : "Irọe anu, Ubạ! busạku ĕndạ̣ kai nirotiang $\mathrm{u}$ sumasĕlle, watụ u kai rimuḷon apa raung-e keren kahẹ̆bunge." Marĕngụ-dĕngụ mĕngkai 'pẹ̆pahẹ̆dông, uté si Ubạ e nẹ̆buạe." Kutẹu i Waha e sĕngkaḷĕndịewen nasongo suanun Ubạ d. nẹ̆berạe: "Iạ e, si kau ĕndạ̣ semben ikapĕndotong." Kutẹu i Waha e napuḷẹe soḷong bal̦ene, arawe su sĕngkarịĕlone i Ubạ e sen mĕnẹ̆naung mangaḷa buan busạ-e, kutẹu i Waha e sen makạĕnna u i Ubạ sen mĕndotong, ute roken mal̨ukadẹ̆ i Waha e sen dimĕnta, kutẹu man nẹ̆sĕmmạ u Ubạ mangạ̣ạ busạ-e. I Waha e nẹ̆berạe: "I kadudako, anu!" Mẹ̆dẹ̆darendehe u i rĕdua. Angkûng i Ubạ u: "Iạ kawe, mawị e, batụu kawe sasuangku. Tanakarendehẹ̆ si Waha e, i Waha e nawịe su kotọ-e, hẹ̆do rimĕllusẹ̆ u nasuen kânge, wusạ e; uté kinaakaḷengke, i Ubạ.

Nahẹ̆pusẹ̆. 


\section{VERTALING.}

\section{Verhaal van de Twee Apen.}

Er waren eens twee Apen en die beiden bewoonden ieder hun huis. Eens op een keer ontmoetten zij elkaar. En daar was ook eeı pisang-stek. En met dat de eene Aap dat pisang-stek gezien had, sprak hij af met den anderen Aap, aldus: "Komaan, vriend, laat ons elk een pisang-stek poten." De andere Aap antwoordde: En daar is er maar één, vriend!" De eene Aap zeide: "Trek het maar uit, vriend!" De andere Aap groef het toen met een wiedmes uit. De eene Aap zeide: "Voor mij is de top, omdat daar al bladeren aan zijn, en het na slechts weinig wachtens al vruchten geven zal. "Goed", zeide de andere Aap "neem dat voor u, voor mij zij dan maar het benedeneind van den stam, al duurt het dan ook lang eer hij vruchten krijgt." De eene Aap was daarop in zijn schik, omdat het zijne al bladeren had en hij zeide: "Mijn stuk zal ik planten aan den weg, om het te laten zien de voorbijgangers." De andere Aap zeide: "Het mijne zal ik planten op mịn erf, opdat ik het steeds iederen dag kan zien."

Twee dagen daarna ging de andere Aap een bezoek brengen aan den eenen Aap, tevens willende diens pisang bezien. En de andere Aap ontmoette op den weg den eenen Aap, die reeds op weg was om naar zijn pisang te gaan zien. De andere Aap zeide: "Vriend, laat ons beiden naar uwen pisang gaan kijken." En ziet, de pisang van den eenen Aap was verdord.

De eene Aap zeide: "Ach, vriend Aap, mijn pisang is betooverd door de voorbijgangers, omdat zij begeerig waren naar iets waarvan de bladeren zoo dicht waren." Na een geruimen tijd wachtens, kreeg het gedeelte van den anderen Aap vruchten. En daar kwam de eene Aap op eens weer aan huis bij den anderen Aap en zeide: "Ach, van de uwe kunt gij reeds genieten." Toen ging de eene Aap naar zijn huis terug, maar den volgenden morgen, toen de andere Aap van plan was de vruchten van zijn pisang af te halen, toen begreep de eene Aap, dat de andere Aap er van zou genieten, en vroeg in den morgen kwam de eene Aap reeds aan, en kwam den anderen Aap tegen, die zijne pisangs ging plukken. De eene Aap zeide: 
"Laat ons beiden 't doen, vriend!" $\mathrm{Nu}$ gingen zij twisten. De andere Aap zeide: "Ik ben het, die er in zal klimmen, omdat 't mijne planting is." Hij kon het niet winnen van den eenen Aap; deze klom in den top en kwam er pas af, toen hij alle pisangs had opgegeten, zoodat de andere Aap bedrogen was.

Ei in d e.

\section{AANTEEKENINGEN.}

De baha is de ongestaarte aap van Celebes, de $u b a$ is de langgestaarte aap. Beide woorden zijn waarschijnlijk van éénen stam:

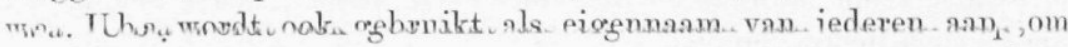
hem er bij te roepen en te noemen, zooals bokẹ voor varkens, mingko voor katten, enz. Dit verhaal herinnert weder aan het onderwerp der boven (bl. 34s) angehaalde verhandeling van Prof. Kern: The Tale of the Tortoise and the Monkey. Toch is het mij niet gelukt het verhaal, zooals het daar is gegeven, volledig in 't Sangireesch terug te vinden. Vgl. ook "the Rat and the Rail" in Codrington's Melanesians, $\mathrm{N}^{\circ}$ 3. - deha of an a u wus? worden de loten genoemd, die naast den pisang-boom uitspruiten en de soort voortplanten. - sarẹ̆tạ is het Skr. Mal. sĕrta. kaduda is juist zulk een verfraaide vorm van kad ua, als badu en buda, zie bl. 234. - manguntang "wachten" is meer Tabukansch; het Mang. zegt mahẹ̆do. — si siạ e, si kau e zijn de uitdrukkingen voor "de, het mijne, uwe" enz.

Nahẹ̆gu. De eene Aap had niets dan het bovenste stuk met den bladkroon, van het pisang-spruitje, en dit kon natuurlijk geen wortel schieten. - rimuḷo, Praet. Perf. van du li o "speeksel", waarvan dumul o "watertanden, begeerig zijn naar". Deze begeerte zou de voorbijgangers er toe gebracht hebben, tooverspreuken of booze blikken tegen het begeerde voorwerp te richten, waardoor het verderven moest. - su an u, zie bl. 278 . 
VIII,

\section{BION DATU R. WOKT I SIRE TELLU TALAHUSE D.} WAHA R. SOAHA.

Tangú piạ Datu r. Woki piạ ahus' i rĕdua esẹ. Tangú angkûng u Woki e: "I kitẹ-ěllu ren tarạ mĕndenọ." Ho, nataraịe. Sarạeng sen su ake, tangú rariọ e nipĕllọe su wowon batu. Sarạeng i rëdua sen mẹ̆dĕndeno, kutẹu kai piạ Baha nanga|ạ dariọ e, kâ̂ Ratu r. Woki e wẹga wue. Tangú rariọ e nipatéen Baha e, wọue' nikinạ-e.

Sarạeng sen bọn nĕndenọ, tangú nakasilọe rariọ e sen tadịc, tarạ̣e rimalingara soḷong kotọ u kalu, kutẹu nakasilóe u rariọ e kai 'kẹ̆kinaseng u Waha e. Tangú nasusáe, i rĕdua. Tangú i rĕdua mĕngkate sụsangị. Kutẹu kai piạ Soaha. Kûng u Soaha u: "I rua kai sụsangị u apa?" Kûng u Ratu e: "Kai sụsangị u anạku, kai nikinạ u Waha, kụ iạ man tamakahĕngang, mĕnsang takụ baļisang kerea'." Kn̂ng u Soaha e: "Lạko mangakạ̦ẹ̆; i kau abe kasusa." "Kụ kai akal̦ẹ̆ kerea'?" Kûng u Soaha e: "Datu e pẹ̆konti pẹ̆tumpate." Tangú angkûng u Woki e: "Kai mẹ̆koạ kerea'?" Kûng u Soaha e, u Ratu e pẹ̆pakeang, mase raļoka, arawe Woki e sang̣i pakaihạ.

Sarạeng sụsangị, kutẹu Waha e rimĕntáe r. nakiwalọe: "I kau kai sụsangị u a', Wawụ?" Kûng u Woki e u: "Kawingku kai nate. Kamagengu wotonge, pauḷiko su Ratun kamene e!" Ho, Waha Ratu e mĕngkate nakikomol’'u kaļawọu waha e. Kûng u waha e u: "Kai nẹ̆tĕmpugẹ̆ kereapa, Tuang?" Kûng u Ratu e: "I kitẹ kai sasaẹ soḷong soa e, mĕlẹ̆bing u Ratu e." Kutẹu piạ baha sĕmbaụ dalakị nẹ̆bera: "E, kapia = kai mangakaḷ̣̆!" Kûng u Ratun baha e: "Pateko, apa ĕndaị daļakị e!" Mĕngkatewe timalang, pirua!

Ho, nasasaẹe, i sire kẹ̆bị. Arawe Soaha e nĕhẹ̆pingke waḷe e, apan lohang-e, r. nẹ̆bera su Ratu ĕndaị dụdaļoka e: "Mageng iạ sen nẹ̆kumbaedẹ̆, ute pakariahíe, Tuang! u sen natĕmpugẹ̆, kụ pakalighạ mẹ̆bangung." Ho, nasuẹe narangeng, Boki e mĕngkate 
ghimunggui, wawerane: "Iạ kai itĕntang si sai!" Kûng u Ratun baha e: "Itẹ̆tĕntang si siạ, Bawụ!" O, sarạeng patikụ baha e nasuẹe narangeng, kutẹu Waha rạ̦aki e tawe rimangeng, kaiso mĕngkai mẹ̆bẹ̆bera: "I kamene kai 'lẹ̆akal̨eng!" Kai Ratun baha e tawe nahimang. Kûng u Soaha e u: "Tukadẹ̆ e pakasueko hẹ̆ping, lukadẹ̆! madirin piạu makasilo si kitẹ." Ho, nasuẹen hẹ̣pinge, patikụ lohang-e. Kûng u Soaha e: "I kitẹ den mĕnalang mẹ̆kumbaedẹ̆!" Kûng u Ratun baha e: "Ho!" Kûng u Soaha e u: "Iạ kai tingihẹ̆ku kadodọ; mapia iạ mawị su paha." Ho, nawịe. Baha e wẹ̆gawen i sie kai sen mangakaḷẹ. Tangú Soaha e nangumbaede, wawerane: "Pakarariahịe, Tuang! sen nasue nahẹ̣ping! Pẹ̆bangungke, sĕmbẹ̆ka peda, sĕmbẹ̆ka pal̨o-palso, Tuang!" Ho, Ratu e mĕngkatewe nẹ̆bangung, bọue' namẹ̆basẹ̆, kụ tawẹ lĕmbene sarang sĕmbaụ, man nasue nate, waha e; lĕmbene man tuḷ̣ewen sĕmbaụ tarimangeng e. Sarạeng nasuen potọe apan su wal̨e e, uté i sie nẹ̆berạe: "Ene! iạ sen mạanu, u kai mạngakaḷ̣̆ ; kaihó tawe nahimang, kụ́!"

VIII. VERTALING.

Verhaal van den Koning, de Koningin, hun kind, den Aap en de Hagedis.

Er waren eens een Koning en eene Koningin, die een zoon hadden. Eens zeide de Koningin: "Laat ons met ons drieën gaan baden." Toen gingen zij heen. Terwijl zij in 't water waren, zetten zij het kind op een steen. Toen zij beiden aan 't baden waren, haalde ineens een Aap het kind weg, doch de Koning en de Koningin wisten het niet. De Aap nu doodde het kind en at het daarna op.

Nadat zij gebaad hadden, zagen zij, dat het kind er niet meer was; zij keken naar den top van een boom, en daar zagen zij, dat het kind door den Aap werd opgegeten. Toen waren zij beide bedroefd. En zij beiden weenden zeer. Toen was daar eene Hagedis. De Hagedis zeide: "Waarom weent gij beiden?" De Koning zeide: 
"Wij weenen om mijn kind, 't is opgegeten door een Aap, en ik begrijp niet hoe ik daarover wraak zal nemen." De Hagedis zeide: "Laat mij eene list verzinnen, wees gij niet bedroefd." "En wat voor eene list?" De Hagedis zeide: "Laat de Koning zich houden, alsof hij zich zelven gedood heeft." De Koningin zeide: "Hoe zal hij dat doen?" De Hagedis zeide, dat de Koning zich moest aankleeden, en daarna gaan liggen, en dat de Koningin hevig moest weenen.

Terwijl zij weende, kwam ineens de Aap daar aan en vroeg: "Waarover weent gij, Mevrouw?" De Vorstin zeide: "Mijn gemaal is overleden. Wanneer gij kunt, zoo boodschap het uwen Koning." Daarop liet de Apenkoning alle Apen komen. De Apen zeiden: "Waarom hebt gij ons verzameld, Heer?" De Vorst zeide: "Wij zullen naar beneden gaan, naar de stad, den·Koning begraven." Toen was daar een ellendig er uitziende Aap, die zeide: "Past maar op, 't kon zijn, dat zij u beet nemen." De Koning der Apen zeide: "Doodt dien ellendigen." Toen vluchtte het arme dier.

Daarop gingen zij allen naar beneden. De Hagedis echter had alle openingen van het huis gesloten en zeide tot den Koning, die daar lag: "Wanneer ik ga zingen, zoo maak u gereed, Heer, want dan zijn ze al verzameld, en sta dan spoedig op." Toen zij allen naar boven waren gegaan, hief de Koningin een weeklacht aan, zeggende: "Aan wien zal ik worden achtergelaten!" De Koning der Apen zeide: "Aan mij wordt gij achtergelaten, Mevrouw !"

Toen alle Apen naar boven gingen, ging de ellendige Aap niet naar boven, maar zeide: "Gijlieden wordt bedrogen!" Doch de Koning der Apen geloofde het niet. De Hagedis zeide: "Slnit al de deuren, wachters, opdat niemand ons zien kunne." Daarop werden alle openingen gesloten. De Hagedis zeide: "Laat ons spelen en zingen!" "Goed", zeide de Koning der Apen. De Hagedis zeide: "Ik heb eene zwakke stem; 't zou goed zijn, dat ik op de rookvliering klom." Zij klom er op. De Aap wist niet, dat zij eene list gebruikte. Daarop zong de Hlagedis een lied, zeggende: "Maak u gereed, Heer, alles is gesloten! Sta op, in de eene hand een houwer, in de andere een werpstok, Heer!" Daarop stond de Koning op en sloeg in de rondte, en er bleef geen enkele aap over, zij allen, de apen, stierven; die overbleef was slechts de eene die niet naar boven was gegaan. Toen allen die in 't huis waren, geslacht waren, zeide hij: "Zie, ik zeide het al, dat men bedroog, maar, ze hebben mij niet geloofd." 


\section{AANTEEKENINGEN.}

Talahusẹ̆ is samengesteld uit taha (bl. 77) en ahusẹ̆. Over de afwisseling van 1 met $\mathrm{h}$, waar twee opeenvolgende lettergrepen met $\mathrm{h}$ zouden beginnen, zie bl. 5l. A hus ẹ is het hooge woord voor anạ; het bet. eigenlijk "opvolger", vgl. mangahusẹ̆. Bent mengahus "verwisselen". — i kitẹ ĕllu, zie bl. 238.

Masusa is een Sang. vorming van 't uit 't Mal. overgenomen susah. - Soaha is de leguaan, een groote hagedis, die in 't Mol. Mal. soa-soa heet. - mẹ̆konti dient hier als hulpw.w. "liegen, valschelijk voorgeveu te, doen alsof". Daarom heeft het hoofdww. ook den Imperatief-vorm. - Botonge is, zooals bl. 187 is gezegd, het woord dat den concessief omschrijft, doch 't heeft ook wel eens de bet. van "kunnen, mogelijk zijn" die daaraan grenst. - tĕmpugẹ̆ is een bijjorm van tampung, met een andere eindlettergreep. Andere voorbeelden, zie bl. 28. - mẹ̆kumbaed ẹ̆ (ook mang umb.) bet. "een kakumbaedẹ̆ zingen." Dit is een soort van lofzang of heldenzang, bij doodenfeesten of offerplechtigheden in gebruik en slechts door mannen gezongen. bẹ̆basẹ̆ (m a m.) is gewoonlijk "het hooge gras of de kleine struiken in een tuin afslaan, om hem van dat onkruid te zuiveren." De grondbeteekenis is "geheel en al, tot het laatste toe vernietigen.," vgl. Jav. bebas. 
IX.

BIO PIA KAMBING D. WAHA.

Ené i Waha e kai sụsĕlle. Kutẹu kai piạ Kambing sĕntahanakeng su liang; kụ Kambing e kai mạnẹ̆pa. Kutẹu Waha e kai nẹ̆bera, u Kambing e kai mẻdẹ̆dohang. Kûng-e: "I kau mahunẹ kai mědẹ̆dohang siạ e!" Kûng u Kambing e: "Iạ mangampung, Baha! i kami tahanạ tawe mẹ̆darohang." Kûng u Waha e: "I kamene tawe makapẹ̆dĕndilẹ̆! man mĕdẹ̆dohang, ĕndaịbe tụtą̧imoadẹ̆." Kûng u Kambing e, "Mĕngkatewe wahasan kami." Kûng u Waha e: "Pahẹ̆do, i kau takụ ikalákẹ̆ su Ratu e." Kûng u Kambing e: "Mĕngkate pangalíkẹ̣!"

Ho, mẹ̆gẹ̆gẹ̆gutáe, Waha e namokạe : "Ëndaung su tĕngon kamene, ką̧awọu Mawu Wẹ̆bato, l̦embone i Tuang Datu, su wowone kate Hukumang! iạ kai nẹ̆bawa si Kambing sire tahanạ : kai nẹ̆dohang!" Kûng u Wẹ̆bato e: "Ene, Kambing! uade i kau kai nẹ̣dohang si Waha e!" Kûng u Kambing e: "Tala, mĕngkatewe modon kami!" Tangú naputusẹ̆, u i Waha nasala ; salane mẹ̆kasitírẹ̆ dua ĕllo, měhĕntud'u himang. Sarạeng i Waha e nahurung, kutẹu kai nakačbạ kima sĕmbaụ, kutẹu i sie mĕngkatewe nĕndau, ené nikẹ̆tungken kima e; sarang lłmanabẹ̣, saghẹ e, limane e mĕngkai mạkakệtung. Sarang naral̨ung, nadehọ nate, i Waha e; ho, nahẹ̆pusẹ̆!

\section{VERTALING.}

Verhaal van de Geit en den Aap.

De Aap ging eens langs het strand. En daar was een Geit met hare jongen in eene grot, en de Geiten waren aan 't kauwen. Toen 
zeide de Aap, dat de Geit hem uitschold. "Gij scheldt mij dus uit!" zeide hij. De Geit zeide: "Ik vraag vergeving, Aap! ik en mijne jongen, wij schelden niet." De Aap zeide: "Gijlieden kunt het niet ontkennen! gij scheldt werkelijk, daar gij zoo mommelt." De Geit zeide: "Dat is maar eene gewoonte van ons." De Aap zeide: "Wacht, ik zal n aanklagen bij den Koning." "Klaag maar!" zeide de Geit.

Terwijl zij aan 't procedeeren waren, riep de Aap nit: "Hier voor ulieder aangezicht, Heeren Rijksgrooten, bovenal Mijnheer de Koning, boven wien nog slechts het Oordeel staat! heb ik gebracht de Geit en hare jongen: zij hebben gescholden!" De Rijksgrooten zeiden: "Gij hoort het, Geit, men zegt dat gij den Aap uitgescholden hebt." De Geit zeide: "Neen, dat is zoo onze manier." En de beslissing was, dat de Aap ongelijk had; zijne straf was, om twee dagen kwartier-arbeider te zijn, en koraalsteen aan te dragen. Toen de Aap dook, vond hij eene reuzenschelp; hij greep met de hand er in, en werd daarop geknepen door de reuzenschelp; totdat de koraalriffen door den vloed bedekt werden bleven zijne handen vastgeklemd. Toen het water hoog kwam, stierf de Aap ten slotte, en nu is het uit.

\section{AANTEEKENINGEN.}

Sĕlle (sum.) is "langs de kust of het strand te voet van de eene plaats naar de andere gaan". Sĕléĕng of sĕláeng of sasělêng is de weg langs de kust. - sĕn tahan a keng, van an ạ met 't voorvoegsel taha, 't achtervoegsel eng en daarvoor nog 't voorvoegsel s ĕ*.—dĕndilẹ̆ (m ẹ̆d.) "ontkennen" is waarsch. een geredupliceerde vorm van den stam dilẹ̆, het algemeen gebruikelijke ontkenningswoord in de Filippijnsche talen. Zie verder bl. 181. — ik a lákẹ̆ is eene passief-vorming van kalákẹ̆, 't Holl. "klacht", dat in 't Sang. alleen "aanklacht" beteekent. Het heeft het Holl. accent behouden. - Ĕndaung su tĕngon, enz. is de gewone aanhef 
eener aanklacht. Met hukumang wordt waarschijnlijk wel een gods-oordeel bedoeld, zooals bv. ook in No. $\mathrm{XI} a$ vermeld wordt en dat vroeger werd angewend, als de beslissing niet te geven was. - modo is 't Holl. "mode" uit het Mol. Mal. overgenomen; men gebruikt gewoonlijk 't Skr. Mal. bahasa. 


\section{BIO PIA I WAIAWO, I URANG, I LIPANG, I MELLE I KASILI, I RARAHUNG, I RANSILANG.}

Tangú i sire ene kai nẹ̆gaghighilẹ̆ simenggọ, kụ nanaha sakaeng i sire tuwu-wẹ̆se. Sarang nasuen tahane, nịbawoḷeng soḷong bạ̦e, nịkakoạ i sire; wọue' sarạeng nasuen koạe, tangú i sire nẹ̆paparentan sinasạ d. lurang i sire, r. nĕmpanondo apidẹ̆ nĕlurang. Tangú sarạeng bọeten nělurang, i sire nĕmpẹ̆sake $r$. nĕhĕngkase waḷango, napatiraḷang namundaḷẹ̆. Ené manganguḷing-e i Waḷawo. Tangú sarạeng i sire napĕllọ su l̦oange, i Waḷawo kai narou; tangú i sie mĕngkatewe nĕlikosẹ̆ nanuwu, kụ i sire waḷine e wẹ̆ga wue. Bọu ene augkûng i Waḷawo: "Sakaeng i kitẹ e kai nahẹ̆pi (nabẹ̆ka)!" Tangú i sire nangambangke sakaeng e, kaihó man tanikaambangeng u sẹ̆ga e man kạkạ̦awọ-e. Sarang tanikaambangeng i sire, ené niwonohe su loange. Bọue' i Wạ̧awo e tarạie kimalang soḷong duḷunge, arawe i Mělle nakatěllạ, i Lipang nakakalang, i Kasili nakakalang, i Urang nakakalang, arawe i Rarahung niwonohẹ̆, i Ransilang niwonohẹ̆. Tangú sarạeng i sire narĕnta su ruḷung-e, i sire mĕngkate mạiang su wowon batang; tangú angkûng i Waḷawo u: "Dingang i kitẹ dadẹ niwonohẹ̆ e, rakọko sasaẹ urungen duankataú!" Tangú sasaẹ e kai i Lipang, d. i Kasili. Bọu ene ěndạ̣e nawawa soḷong duḷunge, kụ bodanben biahẹ̆, pirua!

Tangú i sire kẹ̆bị e mĕngkate mạiang. Ené angkûng u sĕngkatau: "Dakọko pẹ̆dorong putung, Urang!" Ho, i Urang e natarạ̣e ralạ bal̨en Tau Maghurang e. Sarang uarĕnta, i sie tawe makarangeng batụ kai tĕmbalatung mararau. Tangú Tau Maghurang e nakiwą̣ọe: "I sai, kai, wawa su rěllahẹ̆ e?" Angkûngben Urang u: "Kai iạ, Bawụ!" Nakiwaḷọe Tau Maghurang e: "I kau kai soḷong apa, Urang?"

"Kai nịdaroloh' i sire radẹ e iapĕdẹ̆dorong putung." Ang̣kûngben Tau Maghurang u: "Endaịe rangeng!"

Tangú taraịewe rumangeng, tawe makarangeng. Tau Maghurang 
e nẹ̆berạe: "Katanạe sene; iạ mangonggọ." Sarạeng nangonggọ, tawe nịlaonggọ su l़ piman Urang e, kai nịtatẹ̆tuhẹ̆ su wadang-e; tangú mĕngkatewe nahamụ, pirua! r. naten loso. Arawe i sire radẹ su apeng e mĕngkai mạhẹ̆do, kai tate rumĕntan putung e, i Urang e. Tangú sĕngkatau e nịdarolohe niapěniatạ si Urang e. Kutẹu sĕngkarumating-e i Urang e kai sen tạ singongone. Tangú wọu ene i sie mĕngkatewe sasaẹ nĕhabarẹ̆ u: "Dala ringang i kitẹ e kai nipaten, Tau Maghurang e." Tangú i Waḷawo e nẹ̆berạe: "Bai, i kitẹ tarạ̣ mangalo Tau rala Maghurang e." I Wậwo nẹ̆bera u: "Iạ su kuḷi u ĕmme." Angkûngbeu Lipang: "Iạ su kelen akẹ." Angkûngben Mĕlle: "Iạ su awun dapulıang." Angkûng i Ransilang: "Iạ su tĕmbalatung." "Arawe iạ" angkûngben Kasili e "su rěllahẹ̆." Tangú i sire nẹ̆koạ kerene.

Bọue' sarạeng nahẹ̆bi, nĕndikọen soḷo, Tau Maghurang e. Sarang bọeten něndikọ u soḷo e, i sie kimâng; sarang nasuen kâng e, nipate soḷo e, kụ i sire mĕngkai marĕmmasẹ̆: darahung e su saḷipị (darěndung). Tangú sarạeng lawọe hẹ̆bi ('kẹ̆kaḷoarane), Waḷawo e nẹ̆berạe angkûng: "Dị, dị, dị!" Tau Maghurang e manontong saḷipị e, masusụ u Rarahung e; tangú surang nasusụ, nẹ̆deạe putung 'pangutụ Baļawo e. Sarang mangạ̣a, i Mĕlle mĕngkatewe nangaesẹ̆; i sie napuḷing; tangú nẹ̆deạe akẹ; sarang i sie mĕnděmmuse, nikikin Lipang e su mohong-e, wọu ene tanaẹ limintụ soḷong děllahẹ̆ mẹ̆deạ undang, nakatahida Kasili maḷiewehẹ̆; tangú něliondohẹ̆. Sarang nĕliondohẹ̆, niĕntungang u Ransilang e su tĕmbọ-e, wọue' i sie nate. Sarang nate, nịdarĕmmẹ i sire su kĕhu.

Nahẹ̆pusẹ̆.

\section{VERTALING.}

Verhaal van de Muis, de Garnaal, den Duizendpoot, het Loophoen, den Paling, de Naald en het Aanbeeld.

Dezen kwamen overeen om te gaan varen, en kapten tot prauw voor zich een stuk suikerriet. Toen het bekapt was, werd het naar 
huis gesleept en door hen bewerkt; daarna, toen het afgemaakt was, droegen zij elkander op, om te zorgen voor gekookt eten en lading voor zich en schoven zij de prauw af, en laadden haar meteen. En toen zij geladen hadden, gingen zij aan boord, lichtten het anker en gingen terstond onder zeil. De Muis nu was de stuurman. Toen zij in 't ruime sop waren, kreeg de Muis dorst en ging heimelijk aan 't suikerriet knabbelen, en de anderen wisten het niet. Daarna zeide de Muis: "Onze schuit is gebroken". Toen trachtten zij de schuit te redden, maar zij kon niet meer gered worden, want het binnendringende water nam steeds toe. Toen zij haar niet meer konden redden, zonk zij in volle zee. De Muis zwom daarop naar land, doch het Loophoen kon vliegen, de Duizendpoot kon zwemmen, de Paling kon zwemmen, de Garnaal kon zwemmen, maar de Naald zonk en het Aanbeeld zonk. Toen zij aan land gekomen waren, zaten zij een heele poos op een boomstam; en de Muis zeide: "Gaat twee van U naar onze makkers, die daar gezonken zijn, duiken!" Toen gingen de Duizendpoot en de Paling naar beneden. Daarop brachten zij hen naar land en de stakkerds leefden nog.

En zij allen zaten er maar voortdurend. Toen zeide een van hen: "Komaan, ga eens vuur vragen, Garnaal!" De Garnaal nu ging heen, naar het huis van het Oude Mensch. Toen hij aankwam, kon hij de trap niet opkomen, omdat de treden te ver van elkander stonden. Daarop vroeg het Oude Mensch: "Wie is daar beneden op het erf?" De Garnaal zeide: "Ik ben het, Mevrouw !" De Oude Vrouw vroeg: "Waar gaat ge heen, Garnaal?"

"Ik ben gezonden door hen daar ginds, om vuur te vragen."

"Kom dan maar boven!" zeide de Oude Vrouw.

En toen, naar boven willende gaan, kon hij niet. De Oude Vrouw zeide: "Blijf daar maar, ik zal 't u geven." Toen zij het zou geven, gaf zij het niet in de hand van de Garnaal, maar legde de kolen op zijn lichaam, en toen werd het arme dier rood en schroeide dood. De anderen echter op het strand wachtten aldoor, maar de Garnaal kwam niet met vuur. Daarop werd een van hen uitgezonden, om naar de Garnaal te gaan zien. En toen hij ånkwam, had de Garnaal reeds den adem uitgeblazen. En daarop ging hij spoedig terug, de tijding brengen: "Onze makker daarginds is door de Oude Vrouw gedood". Daarop zeide de Muis: "Komt, laat ons die Oude Vrouw gaan aanvallen." De Muis zeide, "Ik ga in het rijstvat." De Duizendpoot zeide: "Ik ga in de water- 
bamboe." Het Loophoen zeide: "Ik op de asch van de stookplaats." Het Aanbeeld zeide: "Ik ga op de trap." "Maar ik ", zeide de Paling, "ga op het erf." En alzoo deden zij.

Toen het.vervolgens nacht was geworden, stak de Oude Vrouw een lamp aan. Nadat zij de lamp had aangestoken, ging zij eten; toen zij gegeten had, doofde zij de lamp uit, en zij bleven maar steeds rustig: de Naald stak in den wand. Toen het reeds ver in den nacht was (middernacht), zeide de Muis "piep, piep, piep!". Wanneer de Oude Vrouw nu tegen den wand sloeg, werd zij telkens door de Naald gestoken, en toen zij gestoken was, zocht zij vuur om naar de Muis te zien. Toen zij dit wilde nemen, stoof het Loophoen met asch, en kreeg zij de oogen vol; daarop zocht zij water; toen zij zich 't gezicht wilde wasschen, beet haar de Duizendpoot aan den mond; daarop ging zij de trap af naar het erf, om heelkruid te zoeken, en trapte op den gladden Paling; toen gleed zij uit. Toen zij uitgleed, viel haar het Aanbeeld op het hoofd, waarop zij stierf. Toen zij gestorven was, wierpen zij haar in het bosch. Einde.

\section{AANTEEKENINGEN.}

Dit verhaal is ook te vinden bij de fabels in het Sea-dialekt, uitgegeven door Dr. Riedel, Tïjdschr. v. I. T. L. V. dl. XVII, 1869. Eenige onbeduidende verschillen kunnen daargelaten worden. Eene veel kortere redactie van dit verhaal, waarbij nog de Hamer (i Rarupa) een der personen is, verschilt te-weinig van deze lezing om afzonderlijke uitgaaf te verdienen. Dáar zoekt de Hamer een plaats tusschen de katoe-bladen boven de trap, terwijl de Paling op den drempel boven aan de trap, en het Aanbeeld beneden vóór de trap zich plaatst. De Oude Vrouw glijdt op de Paling uit, valt op het Aanbeeld, en wordt gedood door den Hamer, die door het schudden op haar valt. De Hamer behoort er bij, en dit slot van 't verhaal is het juiste.

Tuw u-w ẹ̆se is eene soort van suikerriet, aldus genoemd, omdat 
er zoovele barsten (bẹ̆se) in zijn. - mělle is de naam van den Moleo (Mehacephalon moleo) of het loophoen, een aan Celebes eigenaardig dier, dat ook op de Sangir-eilanden voorkomt. - nakatĕllạ en nakakalang wil zeggen: "kon zich redden, redde zich, door te vliegen, te zwemmen." - tẹ̆tuh ẹ̆ is een kool, behalve de smeedkolen van sago-baru-bast (bala a) gebrand, die boheng heeten. De ww.lijke vorm manệtuhẹ̈ beteekent "kolen afschudden of afslaan op". - mapĕniatạ is met 't voorv. mapĕ (bl. 118) gevormd van 't Mal. njata en is dus syn. met Mal. mĕnjatakan. De halfgesloten uitspraak der laatste lettergreep dient om de a voor verzwakking te bewaren. Zie bl. 39. - kuli $\mathrm{u}$ ëmme is een van boombast gemaakt vat, waarin men de rijst bewaart. - kele is een korte water-bamboe, met een haakje, om op te hangen. - salpipị is een wand van aan elkaar genaaide sẹ̆sa-bladeren. 
XI.

Van dit verhaal zijn hier twee lezingen gegeven, daar het verschil groot genoeg is om dit te motiveeren. De Duizendpoot, die in a de eenige manspersoon is, ontbreekt in b. Het verhaal is een niet onaardige schets van een kring waarin wordt kwaadgesproken van de afwezigen, totdat dezen binnenkomen.

XI.

BIO PIA I TUMPEPA, I LEKA, I WALAWO, I LIPANG.

Tangú i Tumpepạ e wawine, i Leka wawine, i Waḷawo wawine, arawe esẹ mang i Lipang sẹ̆sane! Kutẹu i Tumpepạ e natamai soḷong anun Leka, r. nẹ̆bera: "Awui! mohong i Waḷawo e mĕngkai masahiọ u pẹ̆tatako kâng u manga rariọ su walong e." 'Tangú i Leka e natamaịe soḷong anun Baḷawo e, naụ̣i angkûng: "Awui! uade i kau e mĕngkai mẹ̆tẹ̆tako kâng u manga rariọ e!" Tangú angkûng i Wạawo u: "Kẹ̆dike, Awui! tawe kere i sie, u kawawĕlônge "Kạ!" kamaḷkarenge "Kạ!" kere kumakui esẹ e." Bọue’ pinauljewen Tumpepạ si Leka, angkûng: "Awui! pĕnnad'i Awuiku Leka e mĕngkai manipị u sasěllẹ-e su hangubẹ̆ e." Tangú wọu ene i sire nẹ̆tatambạewe nẹ̆baheau si Lipang, angkûng: "Awui! tạ̣ẹ̆tug'i ungkẹku Lipang e mĕngkai maitung u pẹ̆tatumbatine su pẹ̆disẹ̆ e." ·Tangú nipauḷiewen sĕngkatau, angkûng: "Ungkẹ! uade tạ̣ẹ̆tug-u e mĕngkai maitung u pẹ̆tatumbatinu su pẹ̆disẹ̆ e!" Tangú i Lipang e nakireạen Tumpepạ e rĕduan Baļawo e; tangú i sire těllun Leka e nẹ̆tatuntụe su tĕngon Lipang e, kụ (i Lipang e) nẹ̆berạe si Waḷawo e: "Uade i kau kai nẹ̆bera, u tạẹ̆tugẹ̆ku e měngkai maitung u pẹ̆tatumbatiku su pẹ̆disẹ̆ e!" Tangú i Waḷawo e nẹ̆děndilẹ̆, ang- 
kûng: "Kakẹ̆dike, ungkẹ! iạ e tawe nẹ̆bera kerene; iạ kawe nẹ̆bera $\mathrm{u}$ : "Irọe, tạ̣ẹ̆tug'i ungkẹku Jipang e mĕngkai naḷendạ u pĕndarurụ-e." Tangú i Lipang e nẹ̆beráe u: "Uade pěnnad'i Leka mĕngkai manipị u sasụ́-e su hangubẹ̆ e." Tangú i Waḷawo e nẹ̆dĕndile wue, r. nẹ̆bera, angkûng: "Kakẹ̆dike! iạ tawe nẹ̆bera kerene; kawe nẹ̆bera angkûng: "Irọe! pĕnnad'i Awuiku Leka e mĕngkai manipị u puhaneng e." Tangú i Wạ̣awo e nẹ̆berạe wue: "Uade i Awuiku i Tumpepạ e mageng kamą̧ukarenge "Kạ!" kawawĕlônge "Kạ!" Tangú i Leka e nẹ̆dĕndile wue, r. nẹ̆bera, angkûng: "Kakẹ̆dike, Awui! iạ e tawe nẹ̆bera kerene; iạ kawe nẹ̆bera u: "Irọe! tingih' i Awuiku Tumpepạ e kerẹe tingih' u rẹ̆dateng e."

Tangú wọu ene i sire nahurung kẹ̣bị. Sarang nahurung, tangú i sire tĕllu e kinasệpụ i Tumpepạ; i Wal̨awo kinasẹ̆pụ kạimona, masé wọue' i Lipang; kasamuriang-e i Leka, arawe i Tumpepạ e mĕngkai wiahẹ̆.

\section{XIa. VERTALING.}

Verhaal van de Kikvorseh, de Kakkerlak, de Muis en den Duizendpoot.

De Kikvorsch nu was eene vrouw, de Kakkerlak ook, de Muis insgelijks, maar een man was slechts de Duizendpoot alleen. De Kikvorsch nu ging naar de Kakkerlak aan huis en zeide: "Vriendin, de snuit van de Muis is heel spits geworden van het stelen van 't eten der kinderen in de provisie-mand." Toen kwam de Kakkerlak bij de Muis aan huis en sprak: "Vriendin, zij zeggen dat gij steeds 't eten van de kinderen steelt." De Muis zeide: "'t Is niet waar! Vriendin, 't is niet zooals bij haar, des avonds "kạ!" en des morgens "kạ!" alsof zij de mannen riep." Daarop zeide de Kikvorsch tot de Kakkerlak: "Vriendin, de billen mijner vriendin de Kakkerlak zịn heel plat geworden door het gedurig kruipen in de manden." Daarop gingen zij samen spotten over den Duizendpoot, zeggende: "Vriendin, de rug van mijn broer den Duizendpoot is heel zwart van het zich blootstellen aan den heeten zonneschijn." 
En toen ging een van hun hem vertellen: "Men zegt, broeder, dat uw rug heel zwart is van uw gedurig zitten in de zon."

Daarop ontbood de Duizendpoot de Kikvorsch en de Muis, en toen maakten die twee met de Kakkerlak de zaak uit in de tegenwoordigheid van den Duizendpoot, en (deze) zeide tot de Muis: "Men zegt dat gij gezegd hebt, dat mijn rug heel zwart is door mijn zitten in de zon." Doch de Muis ontkende het en zeide: "t Is niet waar, broer, zoo heb ik niet gesproken; ik heb integendeel gezegd: "Ach, de rug van mijn broer den Duizendpoot is geheel glanzig geworden van het land ontginnen." Toen zeide de Duizendpoot: "Men zegt, dat de billen van de Kakkerlak plat geworden zijn van haar binnendringen in de manden." Doch de Muis ontkende op hare beurt dit gezegd te hebben en zeide: "'t Is niet waar, ik heb zoo niet gesproken; ik heb integendeel gezegd: "Ach, de billen van mijne vriendin de Kakkerlak zijn heel plat gedrukt door de weefplank." Daarop zeide de Muis weder: "Men zegt dat mijne vriendin de Kikvorsch 's morgens "K ạ!" roept en 'savonds "K $\mathrm{K}_{\mathrm{a}}$ !" Doch de Kakkerlak ontkende óók, dit gezegd te hebben en zeide: "'t Is niet waar, Vriendin, ik heb zoo iets niet gezegd, maar ik heb gezegd: "Ach, de stem mijner Vriendin de Kikvorsch is als het geluid van de hoogste bamboe an het weefgetouw."

Daarop gingen zij gezamenlijk duiken. Toen zij doken, stikten de drie anderen tegen de Kikvorsch; de Muis stikte het eerst, daarop de Duizendpoot, ten laatste de Kakkerlak, maar de Kikvorsch bleef levend tegen allen.

\section{XIa. AANTEEK ENINGEN.}

Dat kạ van de Kikvorsch is ons "kwak"; 't is het geluid, dat de kikvorsch naar 't gehoor van den Sangirees makt. De beschuldiging vindt haar aanleiding in 't voortdurende roepen. Men lette op het woord kere. - awui is een sasĕnggahị-term, beteekenende "goed vriend". Makiaw u i is "de familie van een meisje om hare hand vragen voor een jonkman". Beneden zal nog worden 
gezegd, door wie dit geschiedt. - na lendạ u pĕndarurụ, nl. glanzig van het gebogen staan in de zon, bij het verbranden van het hout op een ontgonnen land. Pĕndarurụ, dat volgens bl. 93 zou moeten beteekenen "tijd, wijze van ontginnen" is hier in geheel abstracten zin gebruikt. - puhaneng is het nitgeholde plankje, dat de vrouwen tussehen hun rug en het touw, waarmee zij zich 't weefgetouw hebben omgebonden, zetten, om te voorkomen dat het touw doorschuurt. - dẹ̆dateng is de bamboe waaraan in lussen bevestigd is de dẹ̆daḷ ẹ of de lichte bamboe, waarom heen het weefgetouw van boven is geslagen en die een gleuf van 't eene eind tot het andere heeft, opdat zij een geluid make bij 't slaan met de weefpen.

Mahurung is "met zijn velen duiken". Over deze meervoudige beteekenis van $\mathrm{mah}$ is reeds boven op bl. 341 gesproken. "Duiken" is anders murung. Het doel is hier, door een gods-oordeel uit te maken wie gelijk heeft.

In de vertaling zịn Kikvorsch en Kakkerlak opzettelijk als vrouwelijke woorden behandeld, hoewel dit in strijd is met ons taaleigen. 


\section{$\mathrm{XI} /$}

Tangú kai piạ binatang areng-e i Tumpepa, i Waḷawo, i Leka. I sire ene kai mẹ̆tẹ̆tatamba wal̦e sĕmbaụ, kụ sasěnggahị i sire kai i Kia. Tangú i sire kẹ̆bị e mẹ̆tẹ̆tatambúe kerene, ené i Waḷawo kai soḷong akẹ, kutẹu i Tumpepạ e kai nẹ̆sampuhẹ̆, bawerane: "Irọe, Anu! Kia Leka! i Kiaku Waḷawo mohong-e mĕngkai nasahiọ u pẹ̆tatako winen sĕngkawanuâng." Kutẹu i Wal̨awo e kai mẹ̆pẹ̆pahimang su al̨ung u wą̧en sire. Ené, sarạeng i sie nakaringihẹ̆ u i sie kai ipẹ̆sẹ̆sampuhẹ̆, uté i sie mĕngkatewe simangị d. nẹ̆pẹ̆du, wọue' rimangengke $r$. nakiwaļ́e, ungkûng: "Dĕdua! iạ mohongku kai nasahiọ u pẹ̆tatako winen sěngkawanuâng, ěng?" I rědua simimbang: "Tala, Kia Waḷawo! wą̣inewe mẹ̆sẹ̆sampuh' i kau, pakaĕnna wue! i kandua e kawe mạhumbisara u, mohong i Kiaku Wal̦awo e kai nasahiọ u pananoe pile." Bọu ene i Tumpepa e mĕngkatewe nakoạ soḷong akẹ, kutẹu i Wą̧awo e kai nẹ̆sampuh' i, Tumpepa e, wawerane: "Irọe! Kia Leka! i Kiaku Tumpepạ e palang-e mĕngkai nanintạ u kakẹ̆se su watu, arawe pĕnnad-e mĕngkaí nanipị u kakaiang su watu." I Tumpepạ e uté tawe soḷong akẹ, kaiso mẹ̆pẹ̆pahimang su al̨ung. I sie rimangengke r. nẹ̆berạe "Uade iạ kai kakẹ̆seku nakanintạ palangku e?" Simimbang i rĕdua e: "Tala wue, Kia! i kandua mạhumbisara u, pĕnnad-u nanipị u puhaneng." I Leka e soḷtọewen děllahẹ̆. Nẹ̆sampuhe wue i rĕdua: "I Kiaku Leka e mĕngkai nal̨endạ u sasúẹ̆ su petin sĕngkawanuâng." Leka e mẹ̣pẹ̆pahimang, dimangengke r. nẹ̆beráe: "Uade iạ nal̦endạ u sasúẹ̣ petin sĕngkawanuâng." Nẹ̆beráe i rĕdua: "Tala wue; i kandua mạhumbisara, u kai nal̦endạ u pělahákẹ̆; manin su pẹ̆disẹ̆ mĕngkai mělẹ̆hákẹ̆.

\section{XIb. VERTALING.}

Er waren eens dieren, genaamd de Kikvorsch, de Muis en de Kakkerlak. Zij bewoonden gezamenlijk één huis en noemden elkander 
bij den naam K ia. En terwijl zij aldus bijeen waren, ging de Muis zich even verwijderen en toen ging de Kikvorsch kwaadspreken, zeggende: "Ach, Vriendin Kakkerlak, mijne Vriendin de Muis heeft een heel spitsen snuit van het stelen van 't zaaikoren van de heele bevolking." Maar de Muis luisterde af, in de ruimte onder hun huis. En toen zij hoorde dat er kwaad van haar werd gesproken, weende zij en werd boos, en ging daarop naar boven en vroeg: "Zeg eens, gij beiden, ik heb een spitsen snuit van het stelen van allemans zaaikoren, niet waar?" Zij antwoordden: "Neen, Vriendin Muis, wij spraken geen kwaad van u, begrijp het wel, wij spraken er integendeel over, dat de snuit van Vriendin Muis spits is geworden van het brengen van patronen in weefgetouwen." Daarop ging de Kikvorsch zich verwijderen en toen sprak de Muis kwaad van de Kikvorsch, aldus: "Ach, Vriendin Kakkerlak, de dijen van Vriendin Kikvorsch zijn smal geworden van het springen op steenen, en hare billen zijn plat geworden door het zitten op steenen." De Kikvorsch echter was niet naar 't water gegaan, masr had afgelnisterd onder het huis. Zij kwam naar boven en zeide: "Gij zegt dat ik met al dat springen mijne dijen heb smal gemaakt?" Zij zeiden: "Wel neen, Vriendin, wij spraken er over, dat uwe billen plat zijn geworden door de weef-plank." Daarop ging de Kakkerlak naar 't erf. Toen spraken de beide anderen weer kwaad: "Vriendin Kakkerlak is glad geworden van 't kruipen in de kisten van de heele wereld." De Kakkerlak had afgeluisterd, kwam boven en zeide: "Gij zegt, dat ik glad geworden ben van het kruipen in de kisten van de geheele wereld." "Wel neen," zeiden zij "wij spreken er over dat gij glad geworden zijt van het haken; gij zit zelfs in de heete zon te haken."

\section{XI\%. AANTEEK ENINGEN.}

Makoạ solong ake "naar 't water gaan", is eene verbloemde uitdrukking voor "zijne behoeften gaan doen", daar hiervoor meestal het zee-strand of de rivier-oever wordt gekozen. Een verouderende uitdrukking hiervoor is mame u lio "naar den vloer gaan." Blijkbadr waren vroeger de gaten van den vloer de afvoerwegen. - 
soẹ (manoẹ) bet. "met een sasoẹ (een keukengereedschap, dat op een vouwbeen gelijkt) een sago-koek en derg. losmaken en omkeeren." Hier is het gebruikt van 't opnemen - met den langen nagel van de pink - der draden van een weefgetouw, waardoor het patroon (pile) wordt gevormd. De Muis zou dit dan met haren snuit moeten gedaan hebben. - nanintạ en nanipị u kakẹ̆se en kakaiang su watu, nl. de steenen, waarvan de rivieren en beeken op Sangir vol zijn. - m ĕhákẹ̆ is van het Ned. "haken". De namen van dergelijke handwerken zijn alle uit 't Nederlandsch, bv. manitěrikẹ̆, manitópẹ̆, van de gr. w. w. sitĕrikẹ̆ "strijken", sitópẹ̆ "stoppen". De oorspr. klemtoon is behouden gebleven. 
XII.

\section{BIO PIA BAWI R. ASU.}

Kutẹu Asu e kai nẹ̆saḷmbang. Sarang nẹ̆saḷimbang, kutẹu nĕnóte Bawi e. Ho, Wawi e nitụe wue. Saráeng sen bọu kimâng, kûng u Wawi e u: "Karumaheng dĕntako wue". Ho, sĕngkakarumahenge rimĕntáe wúe. Tangú saráeng narĕnta, Asu e mĕngkai lupa. Angkûng u Wawi e: "Puneng ninotẹ̆ kumâng, lupa e mĕngkate tumanịe natumpạ̧iu; lingung lila e kai mạkakiki." Kutẹu Asu e kai limangehẹ̆. Tanẹ̆beran apa, mĕngkatewe timĕmbo; ené i rĕdua nẹ̆kakikịe. Bọue' i rĕdua nẹ̆kakatạ, u mạeng pakel' u Asu r. Wawi ren tanạdĕnta su ĕntana, i sire tawe mẹ̆dame, hakịu sarang fni i sire tawe nẹ̆dẹ̆dame.

Nahẹ̆pusẹ̆.

\section{VERTALING.}

Verhaal van het Varken en den Hond.

De Hond vierde eens feest. Op zijn feest noodigde hij het Varken. Nu, het Varken gaf daaraan gehoor. Nadat zij gegeten hadden, zeide het Varken: "Kom overmorgen eens bij mij!" Den derden dag kwam hij dan ook. Bij zijne aankomst was de Hond buiten adem. Toen zeide het Varken: "Omdat hij ten eten genoodigd is, hijgt hij zoo buitenmate; hij bijt er van op zijn tong". Toen werd de Hond boos. Hij zeide niets maar viel terstond aan, en toen beten 
zij elkander. Daarna spraken zij met elkander af, dat zoolang als de hielen der honden en varkens nog niet op den grond kwamen, zij geen vrede zouden sluiten, zoodat zij tot nu toe nog niet in vrede met elkander leven.

Einde.

\section{AANTEEKENINGEN.}

Mĕnótẹ̣ is van 't Holl. "nooden" gevormd en thans het gewone woord onder de Sangireezen voor "uitnoodigen", in plaats van mamoghe of mamogheng. - puneng is in de N.lijke tongvallen, puhineng in 't Mang. gebruikelijk. - $\mathrm{K}$ at a is uit 't Mal. overgenomen. Mẹ̆katạ bet. in 't Sang. "afscheid nemen", "m ẹ̆kakatạ elkaar bestellen, met elkaar tijd en plaats van samenkomst afspreken" 
BION PIA I ULIDE DEDUAN SALAMISI.

Tangú i rĕdua e kai mẹ̆pẹ̆papangĕnsil'u tako, uade makạsue towo u saroḷo e arau wurạ-e kai i Saļamisi. Kutẹu i Saḷamisi e nẹ̆berạe "Kamageng i kau mạngĕnsilẹ̆ kerene, uté i kadua e kĕnnangko mẹ̆tatahang!" dingangu nẹ̆bera u: "Karumaheng i kadua rumĕnta su saḷoḷọ e!" Tangú wọu ene Saļamisi e sarang su kẹ̆don dĕdua e i sie notongke su rĕndehong, d. nanemọe wuan dĕndehong e; hẹ̆dọewe nangẹ̆do u napenẹ, bọue' nẹ̆bawa ļai wuan dĕndehong e, niapid'i tataghuang, nisĕllẹ su panid-e. Bọue' i sie rimorọ su kalu waḷine, mạhẹ̆dọewe Uḷidẹ̆ e. Tangú wọu ene Uḷidẹ̆ mĕngkatewe kimâng sarangkewen nạaedẹ̆, haki tiang-e nạjiwatu. Tangú Saļamisi e narĕntạe, kạkuine Ulidẹ̆ e: "Uḷidẹ̆! Ulidẹ̆!" boue' Uliidẹ̆ e simimbahe : "Saḷamisi! Salamisi!" Bọue' i rĕdua e nẹ̆sombangke su kalun sarọ̣ọ e, r. nẹ̆kakatạe: "Lima ĕllo, l̦ima hẹ̆bi i kadua mẹ̆tatahang." Tangú i Saļamisi e nangěnnạe: kaḷiman ĕlone sen kasasuen kâng i Ulidẹ̆ e. Tangú nariadịe kerene: su kaĕnnung u ĕlone Uḷidẹ̆ e nĕlome. Tangú Saļamisi e nẹ̆berạe: "Kamageng i kau takụ ikarendehẹ̆, i kau takụ kinaseng." Tangú sarang nahẹ̆bi, Ụ̣iḍ̆ kimuịe: "Saļamisi! Saļamisi!" kaí Saḷamisi e kĕlla wue; tangú Uḷidẹ̆ e kai nẹ̆tako kimâng. Sarang naĕllo, i Sal̦amisi e nĕniatạe, ara kutẹu raung u saroḷọ e nikâng i Uḷidẹ̆. Bọue' i sie natẹ̆togẹ̆ dingangu nate, wọue' Saļamisi e kiminạe si sie.

\section{VERTALING.}

\section{Verhaal van de Rups en de Kolibri.}

Deze beiden beschuldigden elkaar van diefstal: er werd gezegd, dat degeen die de jonge bladeren of de bloesems van de Sarol o opmakte, de Kolibri was. Toen zeide de Kolibri: "Wanneer gij aldus beschuldigt, laat ons dan tegen elkaar vasten" — en hij 
zeide verder: "Overmorgen zullen wị bij de Saroḷo komen." Daarna van toen af tot op den door hen afgesproken tijd ging de Kolibri aan bij een Dĕndehong-boom, en pikte van de vruchten van dien boom, en hield eerst op toen hij vol was, daarna nam hij nog van die vruchten mede, die hij onder zịn vleugels stak. Daarop ging hij op een anderen boom zitten en wachtte op de Rups. Daarna at de Rups, totdat hij geheel verzadigd was, zoodat zijn buik stijf rond was. Toen kwam de Kolibri aan, de Rups roepende: "Rups! Rups!" waarop de Rups antwoordde: "Kolibri! Kolibri!" Daarna ontmoetten zij elkaar op den S a ro zullen wij tegen elkaar vasten." Inmiddels dacht de Kolibri: den vijfden dag is het voedsel van de Rups al verteerd. En zoo geschiede het ook: op den zesden dag was de Rups uitgeput. De Kolibri nu had gezegd: "Indien ik het van u win, eet ik u op." Toen het nacht was geworden, riep de Rups: "Kolibri! Kolibri!" maar de Kolibri was wakker (hoewel hij slapende scheen); en toen ging de Rups in 't geheim eten. Toen het dag was geworden, ging de Kolibri kijken en zie, de $\mathbf{S}$ a ro door de Rups. Daarop werd hij stijf en stierf en de Kolibri at hem op.

\section{AAN'TEEKENINGEN.}

Bio kan met de volgende nitdrukking piạ i Uḷidẹ enz. door de $\mathrm{n}$ verbonden worden, zoodat er dan staat: "Verhaal dat er eens was", enz. Meestal blijft zij achterwege. - mangĕnsil' u tako zie bl. 217 - mẹ̆tatahang is van 't Mal. tahan gevormd en wordt ook in den zin van "uithouden, verdragen", Sang. kẹ̆dang (mẹ̆k ak.) gebruikt. Hier is 't speciaal van "vasten" gebruikt - De saroḷo heet in 't Mal. sajur gedi, de dĕndehong is een djurame-boom. - maļaedẹ̆ bet. "verzadigd, volgegeten." De stam laedẹ̆ bet. "voet", indien van dit woord malpaedẹ is afgeleid, zou het "staande" en dus "stevig, vast, op pooten" moeten beteekenen en aldus het gevoel weergeven van iemand die verzadigd is. - mal iwatu, zie bl. 131. - dendehẹ (dum.) bet. "tegenspreken", maar wordt hier gebruikt als "overwinnen, het winnen van," 
XIV.

BIO PIA MANU D. TĚMPU.

Kutẹu Manụ e kai piạ anạ-e, kutẹu kai nikinạ i Tĕmpu e, kụ man nasuen kinạe, anạ u Manụ e. Kutẹu nangindorẹe makipaten Těmpu e. Tangú nẹ̆sombangken Asu e. Kûng u Asu e: "Unụ́e i kau kakělâng kawe masusa?" Kûng u Manụ e: "Tĕngadẹ̆ iạ masusa, u kai piạ Tĕmpu kiminạ anạku, kụ iạ kai mẹ̆tẹ̆timbang u iạ mamaЏisẹ̆." Kûng u Manụ e: "Iạ kai mạngĕnna u rumĕnta matarang Tĕmpu e mẹ̆tẹ̆tikị, kụ takụ lẹ̆sakeng su matane ruanbẹ̆ka." Kûng u Asu e: "O, i kau kai taumata ką̨ongong; sĕngkapia tanapuko! mageng kai napuko, ute i kau lai kininạ-e." Kûng u Manụ u: "Kai koateng kerea?" "I kau rakọko pẹ̆tako sinsing bulaeng su pasarẹ̆; kaihó abe pẹ̆kumbuni, r. abe tĕllạ pakarangẹ; kamageng i kau sahusuang, abe těllạ mahawesẹ̆; mageng piạ taumata, ute mĕngkai taghaḷ̆ pĕlangehẹ̆; mạeng mal̦antehẹ̆ su waes' u Tĕmpu e, ute sinsing buhụ́e ondoḷẹ̆ su ļohang u Tĕmpu e."

Ho, nakoạe kere'. Sĕngkarumating u pasarẹ̆, mĕngkatewe nẹ̆tako; saráeng taghuang-e nakasilo sinsing kai niạ̣a u Manụ e, ute mĕngkatewe nẹ̆sasahusu; sarang ną̧antehẹ̆ su waes' u Tĕmpu e, tangú taumata nakasilọe Tĕmpu, ute i sire namatẹe Tĕmpu e r. nangạ̦a sinsing. Bọue' Manụ e naụ̣e su Asu e, u Tĕmpu e sen nate. Kûng u Manụ e u: "Iạ kai mamaeh' u apa si kau?" Kûng u Asu e: "Patikụ darotong iạ madiri." Tangú Manụ e nakaĕnnạe r. nẹ̆bera: "Iạ makịtarimakasẹ si kau." Kûng u Asu e: "Enẹe takụ dẹ̆deakeng si kau." 
XIV.

Verhaal van de Kip en de Slang.

De Kip had kuikens en die werden door de Slang opgegeten, en de kuikens werden alle opgegeten. 'Toen dreigde zij de Slang te zullen doen dooden. En zij ontmoette den Hond. De Hond zeide: "Waarom ziet gij er zoo bekommerd uit?" De Kip antwoordde: "Waarlijk ben ik bekommerd, want er heeft een Slang mijne kuikens opgegeten en ik overweeg hoe ik wraak op haar zal nemen." De Hond zeide: "Hoe zult gij u wreken?" De Kip zeide: "Ik denk er over om te komen terwijl de Slang juist slaapt en haar hare beide oogen uit te pikken." De Hond zeide: " $\mathrm{Nu}$, gij zijt een domoor; 't zou gelukkig zijn, als zij niet wakker werd; wanneer zij wakker werd, zoudt gij ook nog door haar opgegeten worden." De Kip zeide: "Hoe moet ik dan doen?" "Ga een gonden ring stelen op de markt, maar verberg, u niet en vlieg niet hoog: wanneer gij achtervolgd wordt, vlieg dan niet vlug; wanneer er menschen zijn, plaag ze dan telkens; wanneer gij gekomen zijt boven het hol der Slang, werp dan den ring in het hol der Slang."

En zoo geschiedde het. Zoodra zij op de markt kwam, stal zij er een; toen de eigenaar zag, dat de ring door de $\mathrm{Kip}$ was weggehaald, jaagde hij haar terstond na; toen zij recht boven het hol der Slang gekomen was, zagen de menschen de Slang en doodden de Slang en namen den ring. Daarop zeide de Kip tot den Hond, dat de Slang al dood was. "Waarmeê zal ik u betalen?" zeide de Kip. "Ik weiger alle goederen," zeide de Hond. Toen begreep de Kip het, en zeide: "Ik breng u mijn dank." "Dat was het, 't welk ik van u vroeg," zeide de Hond. 


\section{AANTEEKENINGEN.}

Tĕmpu is de naam der kleinere soort van slangen; de grootere soort heeten katoang. - matarang, van 't g. w. tarang, beteekent "in rechte lijn komen met, vallen op, samentreffen met", bv. ĕllon taunbarụ ene natarang su ẹ̆llo misa "die Nieuwjaarsdag viel op een Zondag." - Sĕngka pia behoort tot de vormen, op bl. 82 genoemd. De eigenlijke beteekenis is "een goedheid, een gelukkige omstandigheid", vandaar dat 't gebruikt wordt in den zin van: "het zou goed, gelukkig, enz., zijn dat". - mahawesẹ̆, zie bl. 256. - lanteh ẹ̆ is de richting recht tegenover. Su ḷantehẹ̆ku "tegenover mij", dasị, bawa su l.ku "recht boven, beneden mij." - mẹ̆sasahusu is een frequentatieve vorm, zie bl. 197. De op bl. 198 genoemde vorm mananahusu is in overdrachtelijke bet. gebruikelijk ', mẹ̆sasahusu bet. "elkander najagen". - makitarimakase is Maleisch in 't Sang. bestaat voor "bedanken" geene uitdrukking. De laatste zinnen zijn eene soort van moraal, blijkbaar later bijgevoegd en slecht passend bij het gehalte van het geheele verhaal.

Dit verhaal komt zoozeer overeen met Pañcatantra I, 6 (ed. Kosegarten), dat het Sang. stuk de omwerking moet wezen van een vreemden, vermoedelijk Maleischen tekst.

\footnotetext{
1 Men gelieve op bl. 198 , r. 4 mahahusu in manahusu te verbeteren.
}

(Wordt rernolgd) 